\title{
FOREST RESOURCES of South Georgia
}

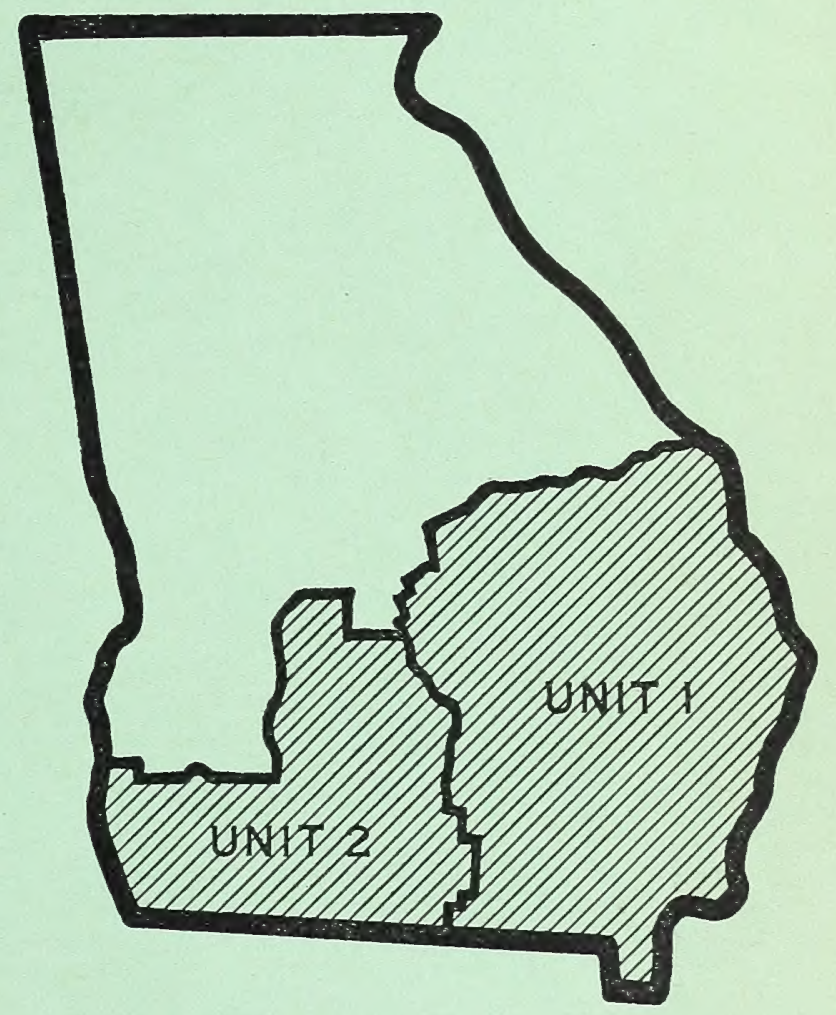

FOREST SERVICE

United States Department of Agriculture Miscellaneous Publication No. 390 


\section{Historic, archived document}

Do not assume content reflects current scientific knowledge, policies, or practices. 
-

- 
UNITED STATES DEPARTMENT OF AGRICULTURE MisCELlaneOUS PUBlication NO. 390 WASHington, D. C., January i94 I

\title{
Forest Resources of
}

\section{South Georgia}

\author{
ghe set \\ by M. M. LEHRBAS, silviculturist \\ and I. F. ELDREDGE, Chief, Field Division, Forest Survey \\ SOUTHERN FOREST EXPERIMENT STATION \\ FOREST SERVICE \\ $\Rightarrow 4 \cdot \sec$
}

Field work in charge of M. M. LEHRBAS, silviculturist

E. B. FAULKS, associate forest economist

and J. W. CRUIKSHANK, associate forest economist

Mensurational analyses in charge of

P. R. WHEELER, forest economist

UNITED STATES GOVERNMENT PRINTING OFFICE - WASHINGTON • 1941

FOR SALE By THE SUPERINTENDENT OF DOCUMENTS, WASHINGTON, D. G., PRICE 20 CENTS 


\section{The Forest Survey}

GFEctive rehabilitation and constructive management of this country's forest resource E require not only protection against neglect and destruction but, with equal urgency, provision for permanent and wise use of that resource. Wisdom in forest land use planning must rest on a long-time economy based on reliable facts as to supply and requirements for wood and other forest products, production and consumption, drain and growth, and the location, area, and condition of existing and prospective forest lands. This requirement for dependable and comprehensive technical information is now being translated into action through the provisions of the McSweeney-McNary Forest Research Act of May 22, 1928, authorizing a Nation-wide Forest Survey.

The Forest Survey, as constituted under that act, is obtaining essential field information and, through interpretation thereof, is aiding in the formulation of guiding principles and policies fundamental to a system of planned management and land use for each forest region and for the Nation.

The fivefold purpose of the Forest Survey is: (1) To make a field inventory of all forest land and of the present supply of timber and other forest products thereon, (2) to ascertain the rate at which this supply is being increased through growth, (3) to determine the rate at which it is being diminished through industrial and domestic uses, windfall, fire, disease, and other causes, (4) to determine the present consumption and the probable future trend in requirements for timber and other forest products, and (5) to interpret and correlate these findings with existing and anticipated economic conditions, as an aid in the formulation of both private and public policies for the most effective and rational use of land suitable for forest production.

It is planned to publish the results of this investigation as they become available. These publications, which apply to large areas and should not be interpreted as portraying correctly the forest situation for small sections that may differ from the average for the entire unit, supply the general framework upon which to base more intensive studies.

The investigation is conducted in the various forest regions by the forest experiment stations of the Forest Service, and in the South by the Southern Forest Experiment Station, with headquarters in New Orleans, La. 

F $\quad \mathrm{O} \quad \mathrm{R} \quad \mathrm{E} \quad \mathrm{S} \quad \mathrm{T}$
$\begin{array}{lllllllll}R & E & S & O & U & R & G & E & S\end{array}$
O F
$\begin{array}{lllll}\mathrm{S} & \mathrm{O} & \mathrm{U} & \mathrm{T} & \mathrm{H}\end{array}$

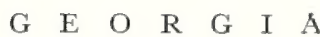

\section{Contents}

Introduction and explanation of terms used

Areas not included in survey

Definition of terms

Summary of findings .

Forest description

Navial stores

Wood products

Forestry measures essential

General description of area

Topography and drainage

Climate

Soils

Erosion

Agriculture

Ownership

Taxation

Forest description .

Forest types

Forest conditions .

Stocking of forest stands

Site quality

Fire damage

Naval stores

Gum naval stores industry

Gum naval stores resources

Future timber supply for gum naval stores

Wood naval stores industry and resources

Wood products

Volume estimates

Saw-timber volumes

Cordwood volumes

Cubic-foot volumes

Poles and piles

Pulpwood .

Forest increment .

Wood-products industries and drain

Comparison of increment with commodity drain :

Future outlook 


\section{Introduction and Explanation of}

\section{Terms Used}

$\rightarrow$

$\mathrm{T}$

HE first permanent English settlement in Georgia was established at Savannah by Oglethorpe in 1733. Prior to that time and for a few years afterwards, much of the coastal region of Georgia was disputed territory, claimed both by the English to the north and the Spanish to the south. The settlement of Georgia following the Revolutionary War was rapid, but took place mainly in the lower Piedmont region of the State. In south Georgia, the population increased very slowly and for many years was confined to narrow strips along the coast and along the larger rivers. In the 1880 's, however, the utilization of the great forests of the interior brought about the building of railroads and the establishment of farms and towns. In 1930, according to the census, the total population in south Georgia, including the unsurveyed area, was 912,000 or 36 persons per square mile, of which 78 percent lived on farms and in small towns of less than 2,500 inhabitants. Nearly 60 percent of the people are native-born whites, 40 percent are Negroes, and only a negligible proportion are foreign-born.

The forest resources of south Georgia, long the support of highly important forest-products industries, have generally received scant consideration from the owners, who have utilized the timber with little or no thought of the future. If these industries are to continue at their present rate or to expand, more intensive management of this resource and more intelligent planning for this region are necessary. In order to formulate sound forest policies that will build up the resource, stabilize forest industries, and thereby make permanent communities, a knowledge of the kind, character, and quantity of timber and of its rate of increase, together with accurate information about the industries engaged in its utilization. is essential.

These data were obtained during the winter and spring of 1933-34. Several three-man crews gridironed the area with east and west compass lines spaced 10 miles apart. At intervals of 660 feet along these lines 19,278 1/4-acre plots were sampled, to furnish evidence of the nature and use of the land and to form the basis for computing the condition of the total area. On the 12,847 forest plots among this number, detailed measurements and observations were recorded covering the size and species of trees, forest type and condition, reproduction, naval stores history, site class, growth, and other information, including fire-damage and erosion data. The data from which volume tables were constructed were collected by J. W. Girard, who also determined tree guides and cull percentages.

Estimates of forest drain for the years 1934-36 were based on production information obtained from operators of representative forest-industrial plants in south Georgia. Naval stores production data are based on a canvass of all the turpentine stills that operated during the 1934-35 cropping season, supplemented by later reports obtained through the Naval Stores Conservation Program and the Bureau of Chemistry and Soils.

Analysis of the inventory data and a discussion of the balance of growth and drain will be given, together with their significance to the industries and communities dependent upon the forest resources. Future requirements for forest products are being studied on a Nation-wide basis and will be treated in separate reports.

This report, which covers the longleaf-slash pine section of south Georgia, includes Georgia Survey 
Units Nos. 1 and 2, hereinafter referred to respectively as southeast and southwest Georgia. A forest survey unit is an area of 4 to 11 million acres in which the forest, economic, and industrial conditions are reasonably homogeneous. The division of a State in this manner facilitates analysis and discussion of the forest situation. The 2 Georgia units here described include 57 counties with a total land surface of $15,297,100$ acres, not including the Okefenokee Swamp in southeast Georgia or the tidal marshes and coastal islands along the Atlantic coast, which are here briefly described in general terms.

\section{Areas Not Included in Survey}

The Okefenokee Swamp covers approximately 412,000 acres, principally in Charlton, Ware, and Clinch Counties of southeast Georgia. It was not included in the line-plot survey because of the extra time and cost necessary to cruise such an area. The name Okefenokee (quivering earth) is of Indian origin and is most appropriate. With the exception of several islands, during a portion of each year the entire area is submerged 1 to several feet.

The swamp is made up largely of cypress bays or hammocks, pine islands, shallow marshes or prairies, and watercourses and lakes. The cypress bays are largely forested in cypress, ${ }^{1}$ tupelos, and several minor species. Some of the bays, particularly those in the western part of the swamp, formerly supported splendid stands of high-grade cypress and blackgum, in which lumber companies operated for many years; other bays support a growth of scattered scrub cypress unsuited for sawlog purposes. The pine islands were originally forested with good stands of both longleaf and slash pine, but with one or two exceptions these areas have been worked for turpentine and cut over. The shallow marshes or prairies, which frequently occupy large contiguous areas, are most prevalent in the eastern half of the swamp. These areas are dotted with small cypress "houses" or "heads" which are in reality small cypress hammocks.

\footnotetext{
1 The lumber-trade term "cypress" is used throughout this publication to designate principally baldcypress (Taxodium distichum), but also includes pondcypress ( $T$. adscendens). Similarly, the lumber-trade term "tupelo" is employed for water tupelo (Nyssa aquatica), and the term "blackgum" for black tupelo (Nyssa sylvatica) and swamp tupelo (N. biflora).
}

Open waterways and narrow shoestring lake are to be found in all parts of the swamp. The Suwannee River originates in the western part of the swamp and flows southwest into the Gulf of Mexico, while the St. Marys River emerges from the southeast corner and flows into the Atlantic Ocean.

The Okefenokee Swamp was largely unsurveyed State property until 1889, when the State land was sold to the Suwannee Canal Co., which attempted to drain and reclaim the area. This gigantic task, known as "Jackson's Folly," was abandoned in the middle nineties as unsound, and the timber resources were placed on the market. Approximately 300,000 acres, including the major portion of the swamp, were purchased by a large lumber company that began logging operations about 1910. From then until 1926, when active operations ceased, approximately 400 million board feet of cypress and about 60 million board feet of pine were removed. No blackgum was logged, and it was believed that over 100 million board feet were left standing in the areas cut for cypress. Since 1926, several small companies have successfully operated in the smaller and more sparsely stocked stands bordering the swamp, and the cutting of cypress railroad ties has long been an activity along the outer rim. A severe fire which swept the swamp in the spring of 1932 and destroyed much of the residual stand caused particularly heavy damage in the western part, where well over one-third of the blackgum was said to be destroyed.

The Bureau of Biological Survey, United States Department of the Interior, has recently acquired approximately 300,000 acres, to be administered as a game and bird refuge. Here the unique and interesting natural conditions can be studied and the vanishing bird and animal life protected and preserved for future generations.

No estimate is here made of the volume of timber left in the Okefenokee Swamp, but it contains a large supply of scattered cypress, blackgum, evergreen magnolia, southern sweetbay, and red maple (mainly in the smaller diameter classes), and also a considerable volume of slash and pond pine along the outer edges.

The other area not included in the field survey consists of approximately $384,2.00$ acres of tidal marshes and offshore islands along the Atlantic coast, shown in white on the type map at the back 
of this publication. The tidal marshes, which may be several miles wide, extend along the entire coast from South Carolina to Florida. Eight large offshore island groups, Tybee, Skidaway, Ossabaw, St. Catherines, Sapelo, St. Simon, Jekyl, and Cumberland, make up the remaining acreage.

The last six of these islands, known as the Golden Isles of Guale, and the accompanying narrow strip of mainland, were settled by the Spanish in the sixteenth century. After the English settlement of the Colony of Georgia by Oglethorpe, large plantations were established where indigo and staple food crops were produced. Following the Revolutionary War, the production of sea-island cotton became a leading and prosperous industry, enabling these islands to maintain an aristocracy of planter families that led the South in wealth and culture, but during the Civil War these plantations were destroyed and extensive agriculture was abandoned. There was then little or no activity until these islands were purchased in recent years by some of America's richest families. Vast and elaborate estates, exclusive resorts, and wellstocked game reserves and hunting clubs now replace the once prosperous cotton plantations. Although a considerable stand of coastal hardwood and pine timber is scattered throughout the islands, because of their relatively greater value as estates, resorts, etc., it is somewhat unlikely that this timber will be logged commercially.

\section{Definition of Terms}

The following definitions of terms used are given as a help to the reader in comprehending the forest situations here discussed.

\section{Land Use Classes}

Productive forest land.-Forest land that has the qualities essential for the growth of commercial timber.

Nonproductive forest land.-Forest land that does not have the qualities essential for the growth of commercial timber.

Cultivated agricultural land. - Land being used for the production of farm or orchard crops, or that shows evidence of having been so used during the preceding 2 years.

Idle agricultural land.-Cultivated land that has been idle for 2 years or more, but that has not reached the abandoned stage.

Abandoned agricultural land.-Formerly cultivated land that shows distinct signs of having been abandoned for agricultural crop production; no attempt has been made to maintain it as improved pasture.
Improved pasture.-Cleared or open land that is under fence, used primarily for grazing and upon which an attempt has been made to maintain a sod.

Other areas.-Areas included within the corporate limits or suburban and industrial sections of cities and communities; power, rail, and highway rights-of-way; marsh; nonmeandered waterways; and prairie.

\section{Forest Types}

Longleaf pine--Longleaf pine (Pinus palustris) constitutes at least 75 percent of the board-foot volume in sawlog-size stands and at least 75 percent of the dominant and codominant trees in under-sawlog-size stands. This type is found on the drier soils of both the flatwoods and rolling uplands. Scrub oak areas that show promise of coming back to longleaf pine are included in the longleaf type.

Longleaf-slash pine.-Longleaf and slash ( $P$. caribaea) pine together constitute at least 75 percent of the board-foot volume in sawlog-size stands and at least 75 percent of the dominant and codominant trees in under-sawlog-size stands, neither species alone accounting for 75 percent. This type is found in the flatwoods in a few areas that are dry enough for longleaf pine and that have escaped fire for a sufficient length of time to permit the slash pine to become established.

Slash pine.-Slash pine constitutes at least 75 percent of the board-foot volume in sawlog-size stands and at least 75 percent of the dominant and codominant trees in under-sawlogsize stands. This type is confined largely to the flatwoods and adjacent ponds and swamps, that is, to moist situations where sufficient time elapses between fires to permit the establishment of slash pine. Scrub oak areas that show promise of coming back to slash pine are included in the slash pine type.

Slash pine-cypress.-Slash pine and cypress together constitute at least 75 percent of the board-foot volume in sawlog-size stands and at least 75 percent of the dominant and codominant trees in under-saw-log-size stands, neither species alone accounting for 75 percent. This type is found principally in low depressions in the flatwoods, and in deeper swamps and ponds than the pure slash pine type.

Turpentine pines - hardwoods. - Neither pines nor hardwoods alone constitute 75 percent of the board-foot volume in sawlog-size stands, nor 75 percent of the dominant and codominant trees in under-sawlog-size stands; but at least half of the pine component is longleaf and slash.

Nonturpentine pines.-Loblolly (Pinus taeda) shortleaf ( $P$. echinata), pond ( $P$. rigida serotina), sand ( $P$. clausa), or spruce ( $P$. glabra) pines, alone or in mixture, constitute at least 75 percent of the board-foot volume in sawlog-size stands and at least 75 percent of the dominant and codominant trees in under-sawlog-size stands. Scrub oak areas that show promise of coming back to nonturpentine pines are included in the nonturpentine-pine type.

Nonturpentine pines - hardwoods.- Neither pines nor hardwoods alone constitute 75 percent of the board-foot volume in sawlog-size stands, nor 75 percent of the dominant and codominant trees in under-sawlog-size stands; but more than half of the pine consists of nonturpentine pines. 
Bottom-land and swamp hardwoods.-Hardwoods constitute at least 75 percent of the board-foot volume in sawlog-size stands and at least 75 percent of the dominant and codominant trees in under-sawlog-size stands. This type is characteristic of the larger stream bottoms and of swamps, bays, and branch heads.

Upland hardwoods.-Hardwoods constitute at least 75 percent of the board-foot volume in sawlog-size stands and at least 75 percent of the dominant and codominant trees in under-sawlog-size stands. This type is found in the rolling uplands.

Scrub oak-scrub hardwoods. - Scrubby or stunted oaks and hardwoods that have come in after fire or cutting characterize this type, which usually occupies areas in the rolling uplands originally stocked with longleaf pine. If these areas show promise of coming back to pine, they are so classified.

Cypress - tupelo.-Cypress and tupelos constitute at least 75 percent of the board-foot volume in sawlog-size stands and at least 75 percent of the dominant and codominant trees in under-sawlog-size stands.

\section{Topographic Situations}

Flatwoods.-Low, flat topography with resulting poor drainage; the soils are generally sandy and usually support a stand of mixed pines.

Rolling uplands,-Rolling or hilly topography, with welldrained, light soils.

Swamps, bays, ponds, and branch heads.-These topographic situations are grouped because of the similarity in their physical features and in the timber species they support. They are low, wet, poorly drained areas, frequently under water, supporting such key species as cypress, black, swamp, and water tupelos, pines, and mixed hardwoods of minor importance.

River bottoms.- These are the bottom lands along the larger stream courses where a bottom-land hardwood association occurs usually admixed more or less with pine. The bottoms generally are well drained but may be subject to inundation. The soils, of alluvial origin, usually are silt loam, sandy loam, or clay loam.

\section{Forest Conditions}

Old-growth uncut. - Old-growth stands from which less than 10 percent of the volume has been cut.

Old-growth partly cut.-Old-growth stands from which 10 percent or more of the volume has been cut, but in which the remaining old-growth sawlog-size timber contains per acre at least 1,000 board feet of hardwood, or 600 board feet of pine or hardwood and pine mixed.

Second-growth sawlog-size uncut.-Second-growth stands from which less than 10 percent of the sawlog-size trees have been cut, and in which the remaining saw timber contains at least 600 board feet per acre.

Second-growth sawlog-size partly cut.-Second-growth stands from which at least 10 percent of the sawlog-size trees have been cut, but in which the remaining saw timber contains at least 400 board feet per acre.
Second-growth under-sawlog-size.-Second-growth stands composed predominantly of under-sawlog-size trees at least 1.0 inch in diameter at breast height (d. b. h.). In uncut stands the saw timber present contains less than 600 board feet per acre. In partly cut stands there is less than 400 board feet of saw timber per acre.

Reproduction.-Areas not falling into any of the other classifications and bearing per acre more than 80 seedlings less than 1.0 inch d. b. h.

Clear-cut. - Cut-over areas on which an insufficient quantity of young growth has come in or been left for them to be classified either as second growth or as reproduction.

\section{Turpentine Area Classifications}

Round timber area.-Areas made up almost entirely of unturpentined longleaf and slash pine stands, ranging from reproduction to old growth.

Working area.-Areas on which trees are being chipped. May be further classified as front-faced if the trees are cupped for their first set of faces, or back-faced if a significant portion has a second set of faces.

Resting area.-Areas which have been worked in the past and which exhibit sufficient opportunities for a second set of faces on worked trees and for a first set of faces on round trees to justify further operations.

Worked-out area.-Areas on which the worked trees are still standing but the turpentining possibilities of the area have been exhausted.

\section{Turpentine Tree Conditions}

Round.-Longleaf and slash pine trees that have never been worked for naval stores.

Working.-Longleaf and slash pine trees that are being worked for naval stores.

Front-faced (or front-cupped).-Longleaf and slash pine trees on which a first face is being worked.

Back-faced (or back-cupped).-Longleaf and slash pine trees on which at least one turpentine face has already been worked and on which a back (second, third, etc.) face is being worked.

Resting.-Previously worked longleaf and slash pine trees that are resting prior to the working of back faces.

Worked-out.-Longleaf and slash pine trees on which as many faces have been worked as the trees will stand. These trees have served their purpose in the production of naval stores and are available for other uses.

\section{Species-Groups}

Pines.-Turpentine: Longleaf and slash pines. Nonturpentine: Loblolly, shortleaf, pond, sand, and spruce pines, and eastern redcedar (Juniperus virginiana).

Hardwoods.-Soft-textured: Sweetgum (Liquidambar styraciflua), black, swamp, and water tupelos, southern sweetbay (Magnolia virginiana australis), red maple (Acer rubrum), southern magnolia (Magnolia grandiftora), and associated minor species. Firm-textured: Oaks (Quercus spp.), ash (Fraxinus 
spp.), elm (Ulmus spp.), hickory (Carya spp., syn., Hicoria spp.), holly (Ilex opaca), persimmon (Diospyros virginiana), ${ }^{2}$ and associated minor species.

\section{Tree Classes}

Sound tree.-A sawlog-size tree that is, or an under-sawlog-size tree that gives promise of becoming, a saw-timber tree.

Sawlog-size tree.-A tree with the following minimum diameter outside of bark: Hardwood, 13.0 inches at $4 \frac{1}{2}$ feet above the ground; cypress, 9.0 inches at $2 \frac{1}{2}$ feet above the butt swell; all pine (except turpentined longleaf and slash pines) 9.0 inches at $4 \frac{1}{2}$ feet above the ground; turpentined longleaf and slash pine, 9.0 inches at 10 feet above the ground.

Saw-timber tree.-A sawlog-size tree that contains one sound butt log at least 12 feet long, or that has at least 50 percent of its gross volume in sound material.

Cull tree.-A sawlog-size tree less than 50-percent sound

2 Since holly and persimmon are used primarily for special purposes, such as bobbins, shuttles, and parts of sporting goods, they were not included in the saw-timber estimate. or so limby, crooked, or otherwise defective as to prohibit its use for saw timber. An under-sawlog-size tree that will not become a saw-timber tree because of limbs, crook, etc., or that is sufficiently unsound to indicate the likelihood of its future loss from the stand.

\section{Diameter Classes}

Two-inch diameter class. - The 10-inch diameter class includes trees from 9.0 to 10.9 inches d. b. h., the 12-inch class, trees from 11.0 to 12.9 inches, etc.

\section{Log Rules}

Doyle log rule.-The formula for a 16-foot log was used: $V=(D-4)^{2}$.

Scribner $\log$ rule.-The formula for a 16 -foot $\log$, with allowance for a $1 / 4$-inch saw kerf, was used: $V=0.79 D^{2}$ $-2 D-4$. This formula was derived by Donald Bruce and Francis X. Schumacher from the values of the original Scribner log rule.

International $\log$ rule. - The formula for a 16-foot log, with allowances for $1 / 2$-inch taper in 4 feet and for a $1 / 4$-inch saw kerf and 1/16-inch shrinkage, was used: $V=0.796 D^{2}$ $-1.375 D-1.23$. 


\section{Summary of Findings}

\section{Area and Land Use}

$\mathrm{T}$ HE gross area surveyed in the 57 counties in south Georgia is $15,297,100$ acres.

The principal land uses are:

\begin{tabular}{lrr} 
& \multicolumn{1}{c}{ Acres } & Percent \\
Forest........... & $10,076,600$ & 65.9 \\
Agricultural........ & $4,754,700$ & 31.1 \\
Other........... & 465,800 & 3.0
\end{tabular}

\section{Forest Description}

More than 7 million acres, or 71 percent of the forest area, is dominated by turpentine pines; the remainder by nonturpentine pines, hardwoods, and cypress.

Only 16 percent of the forest area, or over $1 \frac{1}{2}$ million acres, is old growth, and more than twothirds of this area has been partly cut.

Nearly 77 percent of the forest area, or slightly less than $7 \frac{3}{4}$ million acres, bears thrifty, secondgrowth timber, over two-fifths of which has reached sawlog size.

About 7 percent, or almost three-quarters of a million acres, is clear-cut; of this over one-quarter of a million acres in the pine types have insufficient seed trees to restock the land naturally and probably will have to be planted if prompt restocking is desired.

\section{Naval Stores}

In south Georgia more than 630 active stills produced 287,000 naval stores units in 1933-34, or approximately 56 percent of the total United States production of gum naval stores.

The turpentine area of 7,961,300 acres is made up of the following: Round-timber areas, 19 percent; working areas, 49 percent; and worked-out or resting areas, 32 percent.
Nearly $3 \frac{1}{2}$ million acres, or 88 percent of the 4 million acres classified as working turpentine area, were being worked for a second set of faces. This, together with the fact that about 30 percent of the trees being worked for turpentine were less than 9 inches d. b. h. ${ }^{3}$, shows the intensity of naval stores operations.

Approximately three times as many virgin cups were hung in the peak season of 1933-34 as in each of the two preceding seasons.

In 1934 there were approximately 231/2 million worked-out naval stores trees, containing almost 6 million cords of wood. These should be removed from the stand to make room for a new crop of young growing stock, as well as to increase the growth on the remaining trees. Each year the gum naval stores industry in this area abandons approximately a million cords of worked-out timber.

Improved gum-distilling methods and transportation facilities, scarcity of large and well-blocked turpentine orchards, and relatively high lease prices are stimulating the utilization of small, scattered stands heretofore considered unprofitable for gum production.

Owing to the establishment of new markets by gum-cleaning plants and to improved central stills, raw gum is becoming an increasingly important cash crop of the south Georgia farmer.

Nearly 43 percent of the turpentine area is in well-developed turpentine stands averaging 23 possible faces per acre on resting and working trees and on round (unturpentined) trees at least 9 inches d. b. h.; the remainder of the area is in younger and lighter stands.

The annual income of round trees 9 inches and larger on the $3 \frac{1}{2}$ million acres classified as well-

${ }^{3}$ D. b. h. $=$ diameter at breast height, or 4.5 feet from ground. 
developed turpentine area can support on a sustained-yield basis for the 8-year period 1935-42 a total working body with an estimated annual yield of only 220,000 units; this is 62,000 units less than the average production for the 8 years prior to 1937 . Only by dipping into the supply of round trees below 9 inches d. b. h. or by exceeding the sustained-yield possibilities from larger diameters, can average production be maintained during the next 8 years.

Almost 2.4 million acres were classified as merchantable stump land, on which there were almost 8 million tons of pine stumps from which wood naval stores could be extracted.

\section{Wood Products}

The total net saw-timber volume in 1934 exceeded 18.5 billion board feet, lumber tally (International 1/4-inch rule), of which approximately 68 percent was in pines, 26 in hardwoods, and 6 in cypress.

Approximately 70 percent of the pine saw-timber volume is in second-growth stands, but only 36 percent of the hardwood and cypress volume is so classified.

In the sawlog-size conditions of the turpentine pine types more than 76 percent of the total volume occurs on 48 percent of the area in stands of at least 2,000 board feet per acre.

Of the total cordwood volume of 107 million cords, approximately 51 percent is in pine, 37 in soft-textured hardwoods and cypress, and 12 in firm-textured hardwoods. (See list of species p. 4.)

More than 36 million trees were classified as suitable for commercial poles, 15 percent of which were at least 35 feet long.

During 1934 the total net effect of turpentining in reducing the growth, increasing the mortality, and in causing a degrade and loss of material in the butts of turpentined trees, amounted to approximately 665 million board feet, lumber tally. The utilization and reduction of this enormous loss is one of the most important forestry problems of south Georgia.

During 1936 the 343 sawmills produced 328 million board feet of lumber, of which 82 percent was pine, 12 was hardwood, and 6 cypress. The total commodity drain for all wood products during 1936 amounted to almost 149 million cubic feet, 45 percent of which was for lumber.
For all species combined, the board-foot drain upon the forest exceeded increment in 1936 by 11 percent, or almost 70 million board feet. Cypress suffered the heaviest overcutting with a deficit of nearly 58 million board feet; pine had a deficit of more than 35 million; but hardwood increment exceeded drain by 23 million board feet.

The cubic-foot increment of the total growing stock for all species combined exceeded drain in 1936 by 7 percent, or 11 million cubic feet. The cubic-foot drain in both pine and cypress exceeded increment, especially of quality material. The offsetting surplus in hardwood increment was principally in young second-growth timber of low value and in the less desirable species.

\section{Forestry Measures Essential}

Although south Georgia has long been noted for its extensive forests and diversified forest-using industries, there is an excellent opportunity here to build up (perhaps to double) the present growing stock. To do so would assure a permanent supply of raw material and thus permit additional industrial expansion. Many areas are still unprotected from fires; openings are in need of artificial restocking; turpentine practices, especially those of the many small gum producers, need further improvement; and many forest stands are stagnated with worked-out turpentine pines, cull trees, and inferior species. To remedy this situation and bring the forests into full productiveness, the following measures appear essential:

1. The effectiveness of fire-control activities and their application to all forest lands within this area must be increased. Recurrent forest fires are responsible for the greater part of the loss that now occurs annually through mortality. The response of the forest to relief from periodic burning is immediate and impressive. Growth is increased, mortality is decreased, and in only a few years thin stands become denser and, if seed trees are present, the openings usually become restocked with fastgrowing, desirable species. Protection from fire will go far toward building up and preserving the growing stock and increasing the amount of wood that annually can be turned safely into industrial uses.

2. Old fields and very large openings that will not restock, or will restock only after a long delay, should be planted, preferably to slash pine. 
3. Less harmful and more conservative operating practices should be followed in the turpentine woods, where mortality is unnecessarily high. Deep chipping, hanging too many cups on each tree, and the working of trees less than 9 inches d. b. h. are practices that result in a decrease in naval stores production and in both the quantity and quality of residual wood. Through skillful management in combining naval stores operations with the harvesting of pulpwood, poles, ties, and sawlogs, increased financial returns can be obtained from turpentine orchards.

4. More intensive forest management should be practiced on all operations; this involves selective logging, improvement cutting, thinning, and a more integrated utilization that will convert into usable commodities material now being wasted or not being used to its fullest advantage. 5. To assure these measures' being accepted and applied, a more intensified program of forestry education, especially among the many thousand small land holders, is badly needed. Extension activities, as organized and equipped at present, are entirely inadequate to give the amount of practical on-the-ground instruction, demonstration, and advice that is required.

6. Finally, research in all phases of forestry, but particularly in the fields of forest management, utilization, naval stores operations, and planting, should be continued and expanded. So many forest owners have taken the first steps in forest management in south Georgia that the demand for sound and tested technique cannot be satisfied by the present sources of information. 


\section{General Description of Area}

$\gg$

$\mathrm{T}$ HE two survey units covered in this publication constitute the heart of the naval stores belt; from them comes more than half the rosin and turpentine produced in the United States. This section is rapidly becoming an important southern center for the production of pulp and paper and, with well-established lumber, pole, and tie industries, is one of the most active forest regions in the United States. Its principal cities are Savannah with a population of 85,000 and Brunswick with a population of 14,000 , according to the 1930 census; both are ports on the Atlantic seaboard and are important centers for naval stores exports. Waycross, Valdosta, and Thomasville, cities of 12,000 to 16,000 , are the principal inland trade centers.

South Georgia is well supplied with transportation facilities. Several major railroad systems provide adequate rail transportation; many hundreds of miles of hard-surfaced, modern highways con- nect the principal cities and towns; and secondary gravel and dirt roads give access to practically all other parts of the area. Truck transportation fleets have established themselves in competition with the waterways and railroads, especially for short hauls. Savannah and Brunswick, which have deep-water harbors, are connected with other Atlantic seaports by the intracoastal waterway. The Savannah, Altamaha, Satilla, and St. Marys Rivers flowing into the Atlantic, and the Flint and Chattahoochee which reach the Gulf of Mexico through the Apalachicola River, are navigable for barges for a considerable distance into the interior. Steamships and modern barge fleets offer excellent transportation facilities to foreign and domestic ports.

Below the fall line the slow-moving rivers within this coastal section are not used for commercial power production, but hydroelectric plants on the upper streams of middle and north Georgia, together with modern steam plants that compete suc-

TABLE 1.-Land area of south Georgia, classified according to land use, $1934^{1}$

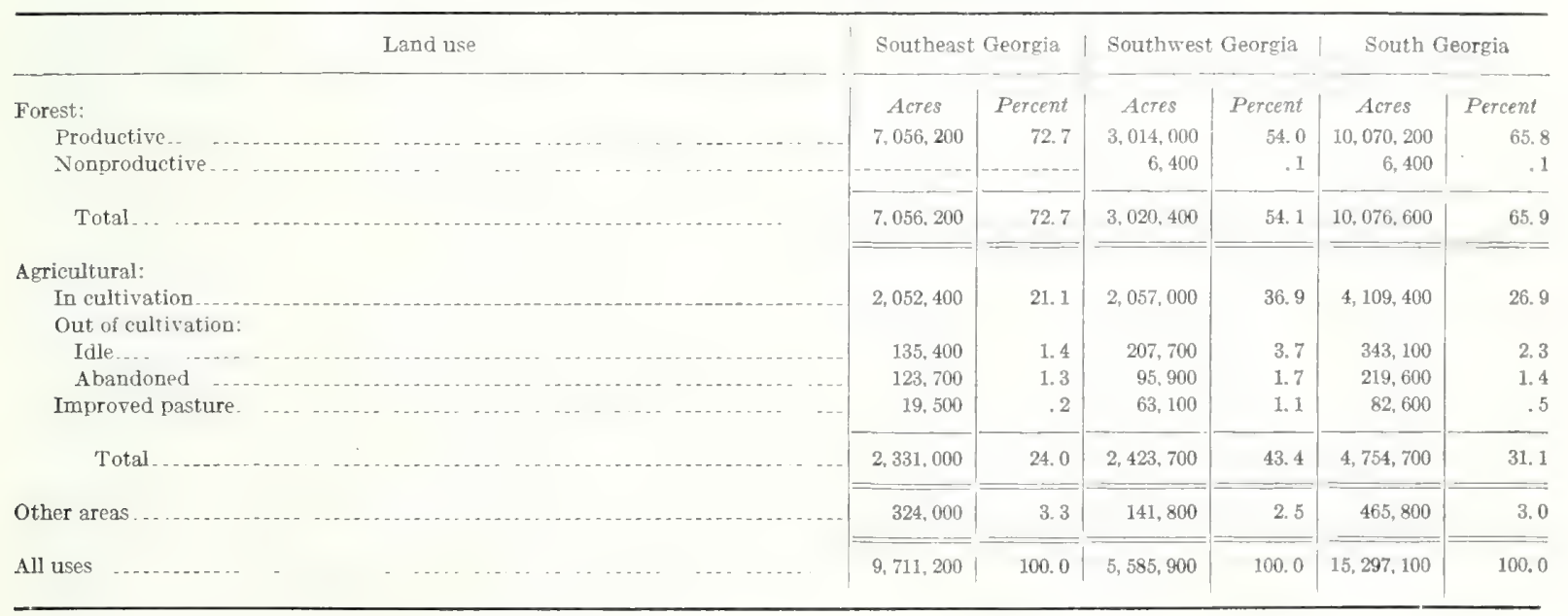

1 Does not include Okefenokee Swamp or coastal islands. 
cessfully with the hydroelectric plants under some conditions, are a source of power for this area. Both coal and fuel oil are obtainable at the seaports at favorable rates, but natural gas is not now available for fuel.

As shown in table 1, 66 percent of the land surface -7 million acres in the southeast unit and 3 million in the southwest-is classified as forest land.

\section{Topography and Drainage}

This area, which lies entirely within the Coastal Plain, has approximately 33 percent of its forest area in the flatwoods, 36 percent in the rolling uplands, and 31 percent in river bottoms, swamps, and ponds. The flatwoods, forming a nearly level, well-watered but poorly drained, sandy plain with numerous wooded ponds and swamps, extend inland on a long gentle slope for 60 to 175 miles to the foot of the Tifton uplands, where the terrain reaches an elevation of approximately 260 feet above sea level. The flatwoods coincide roughly with the longleaf-slash pine-cypress forest type shown in the colored map at the end of this publication. North and west of the flatwoods country are the Tifton uplands, a gently rolling to fairly hilly country that rises to approximately 450 feet above sea level. The country is drained to the south and east by numerous rivers.

\section{Climate}

The climate is favorable to rapid forest growth and is generally healthful for man. The summers are long and warm, the winters short and mild; the mean annual temperature is about $67^{\circ} \mathrm{F}$. June to August is the warmest season with an average of $81^{\circ}$, and December to February is the coldest with a mean of $52^{\circ}$. Periods with temperatures below freezing are brief and infrequent. Zero weather is almost unknown but $-2^{\circ}$ has been recorded in Dodge County. Snowfall is rare, and frosts seldom occur after March 15 or before November 15. The average growing season is about 245 days.

The average annual rainfall of about 50 inches is rather uniformly distributed throughout the year, except that somewhat more than the monthly average occurs in July and August. Dry periods are likely to occur in late spring or early fall. Severe and protracted droughts resulting in very serious fire conditions can be expected at least once in every two or three decades, while about 1 out of every 5 years may be dry with a high fire hazard. Heavy windstorms resulting in widespread damage to timber are infrequent and are generally the result of tropical storms from the Gulf coast. Prevailing winds are from the southwest.

\section{Soils}

Approximately two-thirds of the land surface is made up of well-drained sandy loams and sands. Subject to long, hot summers, fairly heavy rainfall, and year-round leaching, most of these light soils require liberal and repeated applications of fertilizer to produce good crop yields. The poorly drained soils of the lowlands, which make up approximately one-third of the area, have little agricultural value, but longleaf and slash pines thrive here except in the few places where hardpan is near the surface and is thicker and denser than usual.

\section{Erosion}

Erosion is not serious in the flatwoods section, because of the level nature of the terrain, but in the rolling uplands where land clearing and cultivation have developed more extensively much of the exposed soil has eroded. Contour plowing, terracing, and other soil-saving practices, however, have done much to arrest and check erosion in this area. The value of forest cover in the prevention of erosion is clearly indicated by the fact that while 10 percent of the cultivated land shows evidence of marked erosion, this is true of less than 2 percent of the forest land.

\section{Agriculture}

Notwithstanding the fact that 66 percent of the southern area is in forest, the leading source of employment is agriculture, which according to the 1930 census furnishes work for half of the gainfully employed workers. In southwest Georgia the Forest Survey classified 43 percent of the area as agricultural, but in southeast Georgia, including the flatwoods, only 24 percent. The agricultural census of 1935 listed more than 83,000 farms in the area. These average 115 acres, of which 59 acres 


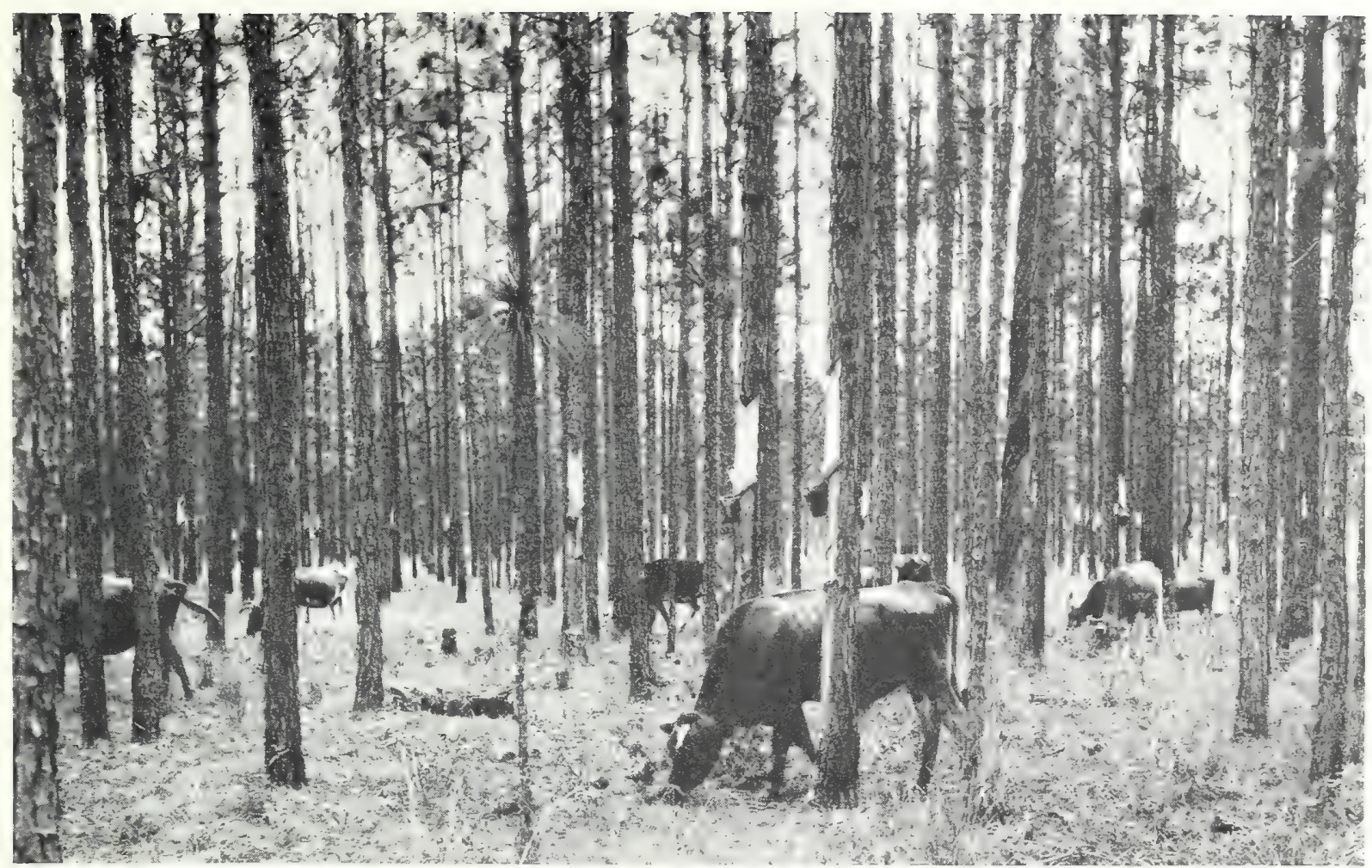

FIGURE 1.-Cattle grazing in second-growth longleaf pine being worked for nar'al stores. Note the large number of round trees just under turpentining size.

was in farm woodland. The total value of farm land and buildings was listed as $\$ 156,000,000$, or an average value per farm of slightly less than $\$ 1,880$. Two-thirds of the farmers are tenants, sharecroppers, or managers, and only one-third own the farms they work.

Corn, the most extensively planted crop, in 1934 occupied over half the harvested cropland, with the low average yield of approximately 8 bushels per acre. One-fifth of the cropland was planted to cotton, with an average yield of 0.4 bale per acre. Other crops are forage plants, small grains, sweetpotatoes, tobacco, sugarcane, watermelons, and pecans. Also many beef cattle and hogs are raised on open range throughout the area (fig. 1). Although regular farm crops are the chief sources of farm income, naval stores gum from longleaf and slash pine trees and pulpwood from many species are rapidly becoming important sources of cash to the south Georgia farmer as well as of part-time employment for between-season farm labor.

A total of 219,600 acres, or 5 percent of the agri- cultural area, was classified by the Forest Survey as abandoned farm land. These areas probably are reverting to timberland much faster than forest land is being converted to cropland.

\section{Ownership}

According to the 1935 agricultural census, 62 percent of south Georgia, or $9 \frac{1}{2}$ million acres, is in farm ownership. A complete canvass of the naval stores operations, made by the Forest Survey in 1934, revealed that 581 still operators in south Georgia owned more than $13 \frac{3}{4}$ million acres, or 12 percent of the total area. The average size of these holdings was about 3,000 acres.

According to data obtained in $1934-5$ by R. B. Craig in nine representative south Georgia counties, the principal kinds of landowners are farmers, naval stores operators, land speculators, banks and insurance companies, general forest operators, and lumbermen. The predominance of large holdings is indicated by the fact that 4 percent of the landowners own half the land, as shown in figure 2. 


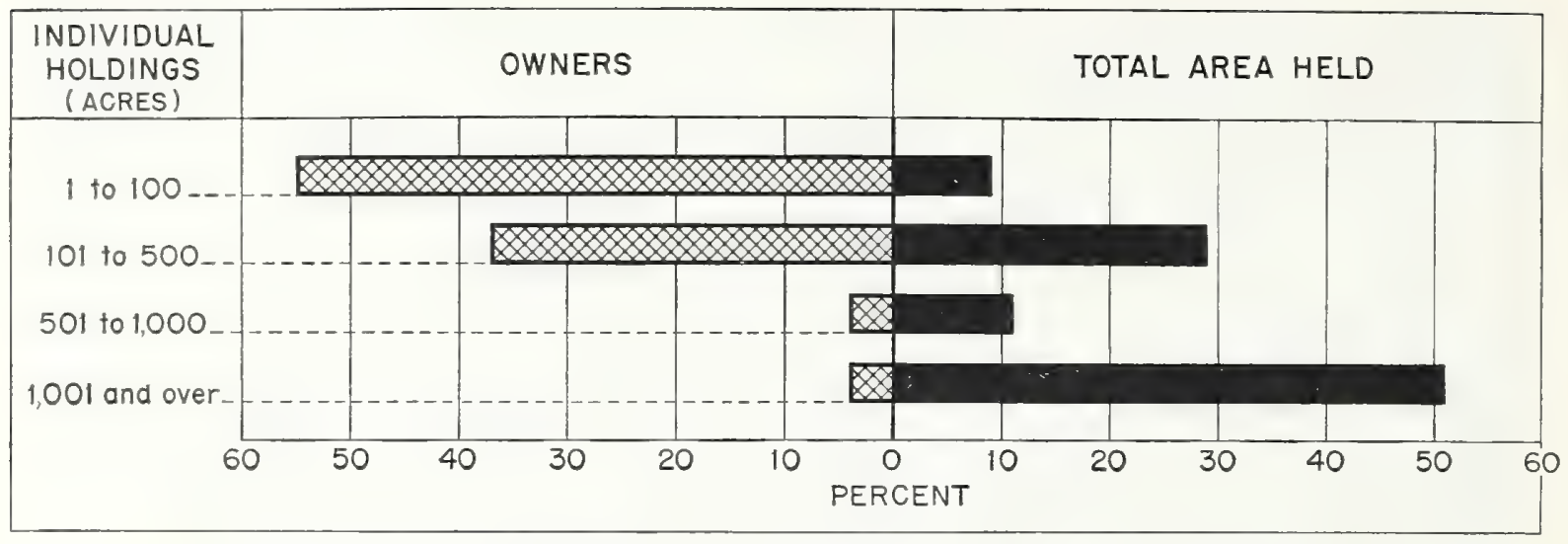

FIGURE 2.-Percent of landowners and areas held, in different size classes of individual holdings.

Since these data were gathered, the trend to large ownerships has been increased, as a result of the acquisition of forest reserves by pulp and paper companies that have recently located along the Atlantic coast. This move has also stimulated purchase of forest lands by lumber, naval stores, and other forest industries.

\section{Taxation}

Law enforcement, administrative supervision and maintenance of public properties, tax assessments and collections, and other important local governmental functions are vested largely in county authorities. This tendency for localization of governing authorities accounts for considerable variation in the tax rate on real estate throughout the area. In Craig's study it was found that in the coastal counties timbered land as well as cut-over land was classified as "wild land" and that the average county-wide assessed valuations ranged from $\$ 0.75$ to $\$ 2$ per acre. Average taxes on this wild land ranged from 2 to 6 cents per acre per year in the various counties. In the more agricultural counties of the uplands, timbered land was assessed from $\$ 3.75$ to $\$ 6.75$ per acre with taxes of 10 to 22 cents per acre; cut-over land was assessed from $\$ 2$ to $\$ 3.50$ with taxes of 6 to 9 cents per acre. The range of average assessed valuation of improved farm land among these nine counties was from $\$ 2$ to $\$ 8$ per acre with taxes at 4 to 23 cents per acre per year. On the whole, however, the taxes on forest lands in south Georgia are low, compared with those in other States.

The amount of tax delinquency varies greatly among the counties. The Southern Region office of the Forest Service estimates that in 1934 over 2 million acres, or about one-sixth of the total land area of the 57 counties, was in tax default for 3 years or more. This period, 1932 to 1934, coincided with the depression, and the situation disclosed must be interpreted accordingly. Twentyeight counties had less than 10 percent of their area with taxes unpaid for 3 years or more, 15 counties were 10 - to 24 -percent delinquent, and 14 counties were 25 percent or more delinquent. The more serious delinquency occurs in 2 groups of counties-1 along the northwest boundary in an area of deep sand, sparse woods, and poor agricultural land, and another farther south in the naval stores area of the flatwoods. Although delinquency reduces seriously the local government revenue, the land rarely reverts to the county or is lost through forfeiture, since it is generally redeemed at a later date. 


\section{Forest Description}

$\mathrm{T}$ HROUGHOUT its history, forests have been the greatest natural resource of south Georgia. With a present forest area of over 10 million acres, principally in young pine, the land surface is today 66 percent forest land, despite the fact that in the last 200 years, the State, as a whole, has developed mainly along agricultural lines. The largest areas of unbroken forests lie in the flatwoods, where the light soils and poor drainage conditions are unfavorable for farming (fig 3.). In the country between Valdosta and Savannah the production of forest commodities is the principal source of income. In the upland sections of south Georgia, however, although the greater portion of the land is still occupied by forest growth, the soils are better and in spite of the discouraging effects of longcontinued erosion and the inroads of the cotton boll weevil farming continues as the principal occupation.

\section{Forest Types}

In the field survey 11 forest types were recognized. In order to simplify the description and

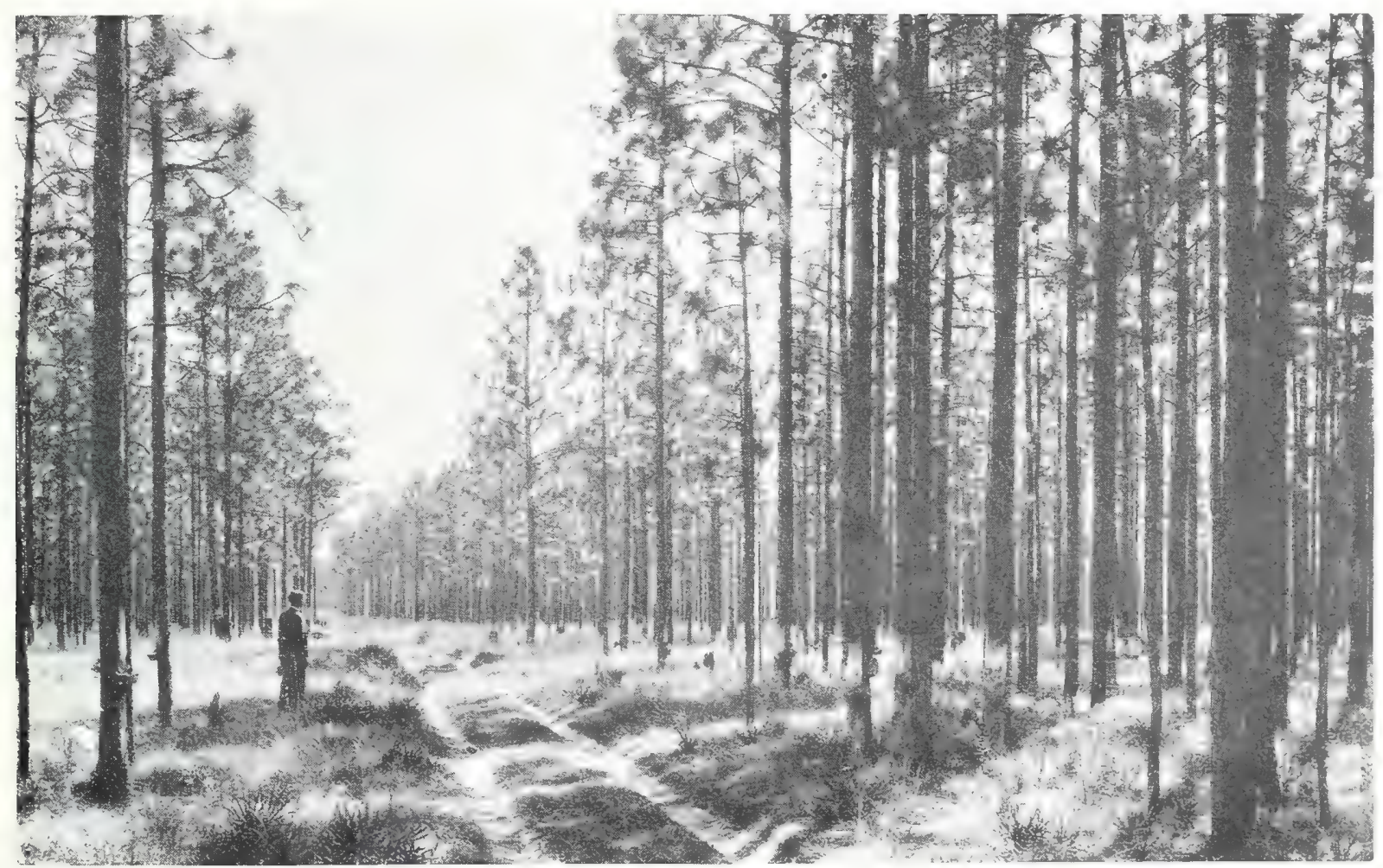

FrGURE 3.-Second-growth longleaf pine in the flatwoods, typical of much of the forest area of south Georgia. The larger trees in this stand are being worked for naval stores. 
TABLE 2.-Forest area of south Georgia, classified according to forest type and topographic siluation

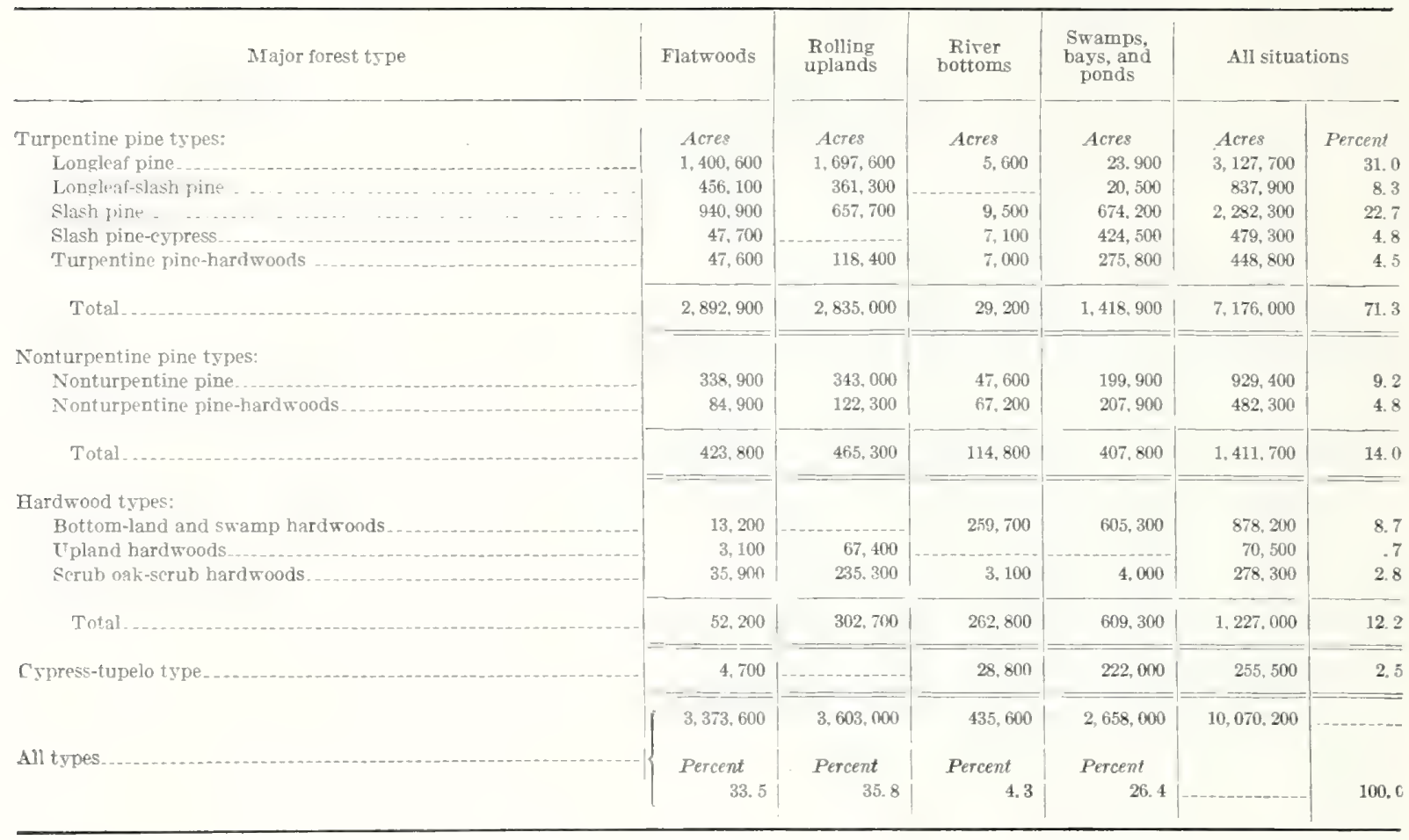

correlation of the data on area, volume, and turpentine history, the forest types and species have been assembled into 4 groups: turpentine pines, nonturpentine pines, hardwoods, and cypress (Taxodium spp.). In the type map at the end of this publication, no effort has been made to locate the 11 forest types or the forest type groups; instead, the map shows those generalized areas in which certain major species are characteristic and dominant. There is obviously no correlation between the broad type areas shown on the map and those shown in the detailed type classification discussed in the tables and the text. Also, because of the small scale used, the narrow, hardwood "stringers" along the streams could not be shown accurately, and the map consequently does not give a true picture of the extent of the area dominated by hardwoods.

\section{Turpentine Pine Types}

The turpentine-pine group, made up of forest types in which the gum-producing species (longleaf and slash) predominate, includes the longleaf pine, longleaf-slash pine, slash pine, slash pine- cypress, and turpentine pine-hardwood types. As shown in table 2, these types characterize about 71 percent of the forest area and are most prevalent in the flatwoods. In these types, slash pine makes up 48 percent and longleaf 28 percent of the cubic volume (table 3). The remainder is composed of loblolly and other pines, cypress, and hardwoods.

\section{Nonturpentine Pine Types}

Nonturpentine pine types, composed largely of loblolly (up to 52 percent of the cubic volume), with some shortleaf, pond, or spruce pine, characterize only 14 percent of the forest area. They are found mainly on the more fertile, well-drained soils along the streams and have taken over much of the abandoned farm land of the uplands. This upland invasion has to some extent taken over areas formerly occupied by old-growth longleaf pine.

Comparison of Mohr's type maps, ${ }^{3}$ published in 1896, with the type map of today shows that during the last 40 years the northern boundary of the

3 Mohr, Charles. the timber pines of the southern united states. U. S. Dept. Agr., Div. Forestry Bul. 13, 37 pp., illus. 1896. 
region characterized by longleaf pine has moved southward along its entire length in Georgia for 20 to 40 miles as the result of invasion of loblolly and shortleaf pines and hardwoods. Within the present longleaf belt, an equally interesting change has been taking place; the proportion of slash pine, and to a less extent loblolly, is steadily increasing in the stands.

\section{Hardwood Types}

The hardwood types occupy 12 percent of the total forest area (table 2). The tupelos supply nearly one-third of the volume; sweetgum, the red oaks, southern sweetbay, and red maple about one-half. Seventy-one percent of the hardwood lands is in fertile soils of the larger stream bottoms and in swamps and branch heads. The remainder is mainly held by the scrub oak-scrub hardwood type, which occurs in small scattered patches throughout the area, usually on the light sandy soils of the Norfolk series where heavy cutting and repeated fires have encouraged blackjack and turkey oaks along with other scrub species to replace the original pines.

TABLE 3.-Composition of forest type groups by species, expressed in percent of net cubic volume (outside bark) ${ }^{1}$

\begin{tabular}{|c|c|c|c|c|c|}
\hline Species & $\mid \begin{array}{c}\text { Turpen- } \\
\text { tine pine }\end{array}$ & $\begin{array}{l}\text { Non- } \\
\text { turpen- } \\
\text { tine pine }\end{array}$ & $\begin{array}{l}\text { Hard- } \\
\text { wood }\end{array}$ & $\begin{array}{l}\mathrm{Cy}- \\
\text { press- } \\
\text { tupelo }\end{array}$ & $\begin{array}{l}\text { All } \\
\text { type } \\
\text { groups }\end{array}$ \\
\hline Longleaf pine . . . . & $\begin{array}{r}\text { Percent } \\
28.2\end{array}$ & $\begin{array}{r}\text { Percent } \\
1.7\end{array}$ & $\begin{array}{r}\text { Percent } \\
0.3\end{array}$ & Percent & $\begin{array}{r}\text { Percent } \\
16.2\end{array}$ \\
\hline Slash pine & 48. 2 & 3.8 & .8 & 2.3 & 28.0 \\
\hline Loblolly pine & 3. 7 & 52.3 & 1.4 & .6 & 13. 1 \\
\hline Other pines ${ }^{2} \ldots$ & 2.4 & 13.2 & .5 & .5 & 4.2 \\
\hline Sweetgum . . . & .6 & 5.9 & 16.9 & 1.5 & 4.9 \\
\hline $\begin{array}{l}\text { Black, swamp, and } \\
\text { water tupelos. }\end{array}$ & 7.3 & 7.2 & 31.7 & 40.3 & 13.4 \\
\hline $\begin{array}{l}\text { Other soft-textured } \\
\text { hardwoods }\end{array}$ & 2.9 & 5.9 & 18.7 & 3.6 & 6.6 \\
\hline Red oaks. & .8 & 5.8 & 13.5 & 1.4 & 4. 3 \\
\hline White oaks & .3 & 1.8 & 4.0 & .9 & 1. 3 \\
\hline Serub oaks............ & .6 & $\left({ }^{3}\right)$ & 1.3 & & .6 \\
\hline $\begin{array}{l}\text { Other firm-textured } \\
\text { hardwoods }\end{array}$ & .1 & 1.5 & 7.9 & 3.2 & 2.0 \\
\hline Special-use species ${ }^{2} \ldots$ & (3) & .2 & .3 & -.--..- & .1 \\
\hline Cypress $\ldots \ldots \ldots$ & 4.9 & .7 & 2.7 & 45.7 & 5.3 \\
\hline All species.... & 100.0 & 100.0 & 100.0 & 100.0 & 100.0 \\
\hline
\end{tabular}

1 Basic figures do not include volume of cull trees, turpentine butts, or tops and limbs of sawlog-size hardwoods and cypress, but do include sound serub oak, which generally is considered cull.

2 See introduction for list of species.

3 Negligible.

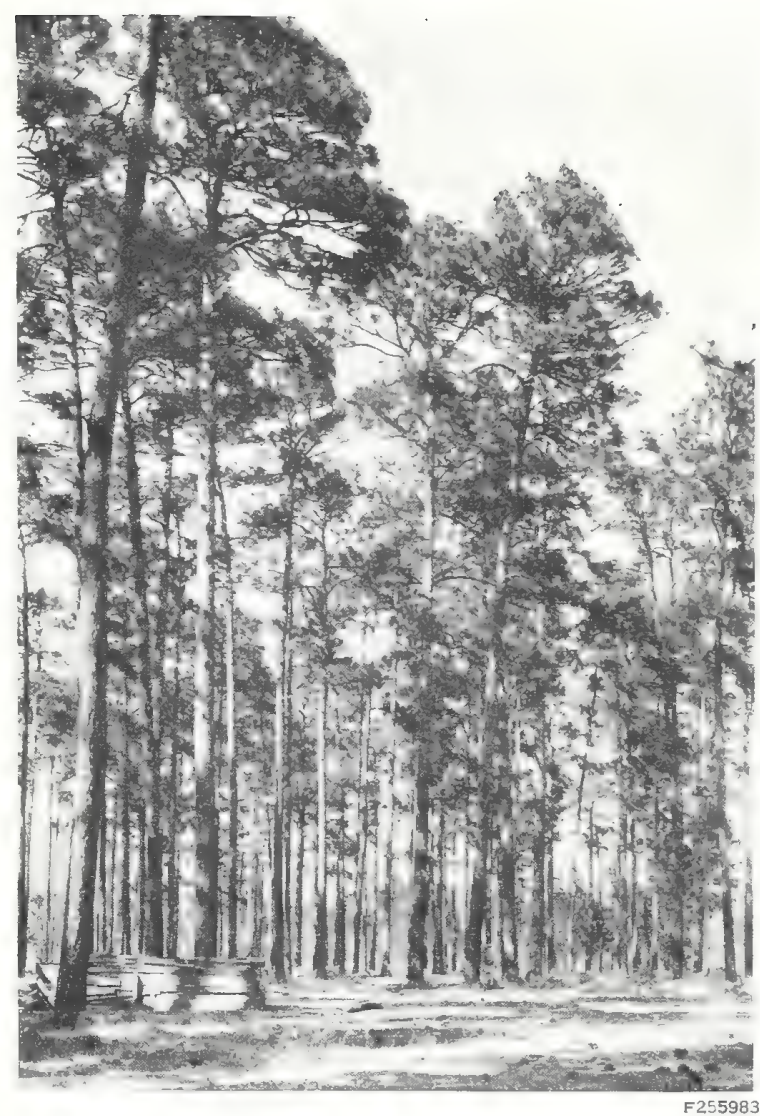

Frgure 4.-Typical old-growth longleaf pine of south Georgia. Most of the old-growth timber in this section is scattered throughout the area in small tracts.

\section{Cypress-Tupelo Type}

The cypress-tupelo type, which occurs in scattered ponds and in swamps and river bottoms throughout the area but chiefly in the flatwoods, makes up less than 3 percent of the forest area. Cypress, the most important wood, contributes 46 percent of the cubic volume in the type; tupelos are next in importance with 40 percent of the type volume. Several hardwoods, principally waterloving species, and pines make up the remaining 14 percent.

\section{Forest Conditions}

To picture adequately the appearance, condition, and economic maturity of the forest stands, it is necessary to consider their classification according to age, size, quality, and the degree to which they have been cut. 


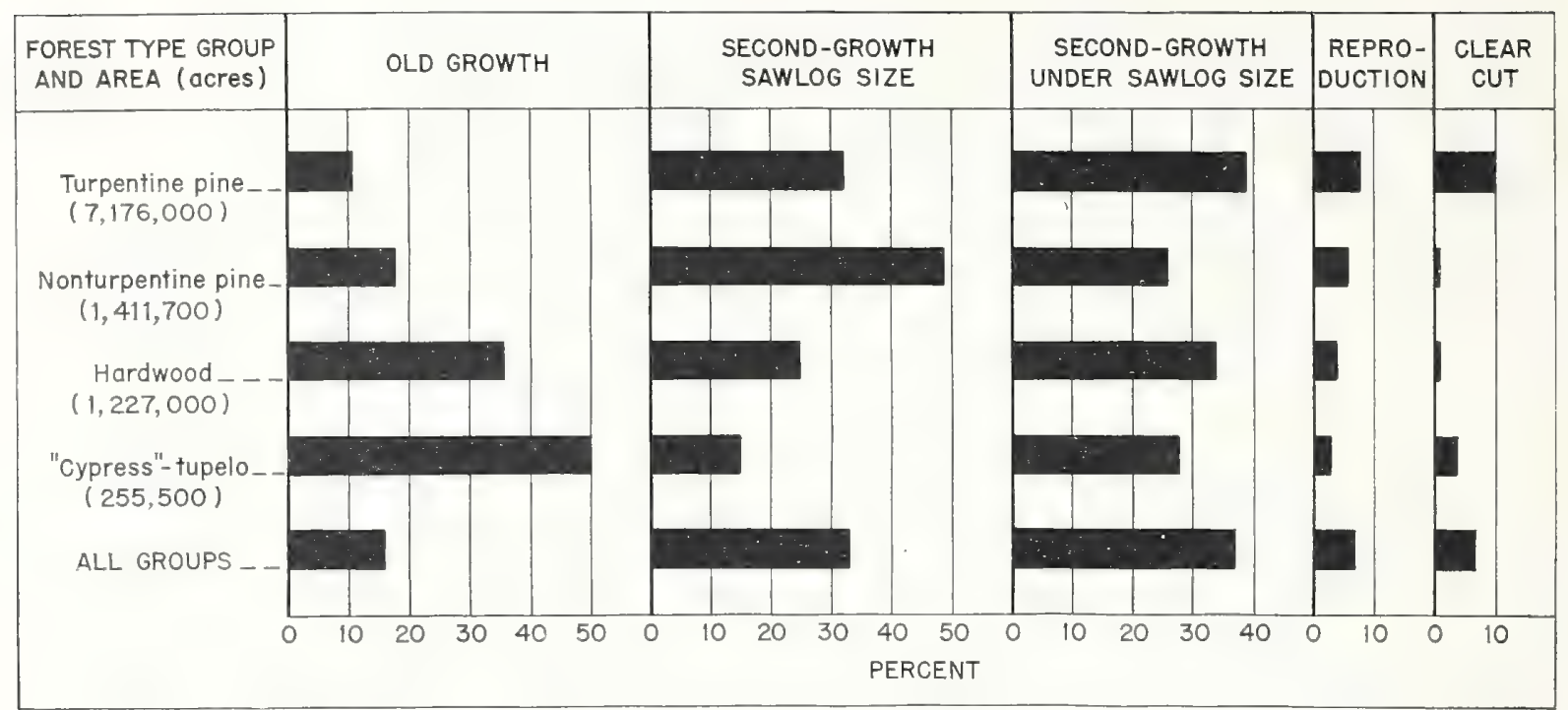

FigURE 5.-Proportion of type-group area in each forest condition, 1934. (Bars for each type group total 100 percent.)

Stands having the characteristics of the original mature forest are called old growth. Figure 4 shows a typical old-growth longleaf stand. Young stands which have come in as a result of cutting or for any other reason are called second growth; they are classified as reproduction, under-sawlog size, or sawlog size, depending upon their stage of development. If 10 percent or more of the board-foot volume in sawlog-size stands, or of the stems in under-sawlog-size stands, has been removed, such stands are known as partly cut. The lower limits of old-growth or sawlog-size second-growth condi- tions represent the lightest stands of each class that in general are included in commercial operations. When cutting reduces a stand below this minimum and fails to leave a minimum stocking of young growth or reproduction, it is considered clear-cut. The area characterized by the several forest corditions in each of the major forest type groups is shown in table 4 and diagrammatically in figure 5.

Of more than $1 \frac{1}{2}$ million acres of old-growth timber, one-third is in uncut stands averaging about 7,000 board feet per acre, or 24 cords (tables 5 and 6). Of the area in uncut old-growth stands,

TABLE 4.-Forest area of south Georgia, classified according to forest condition and type group, 1934

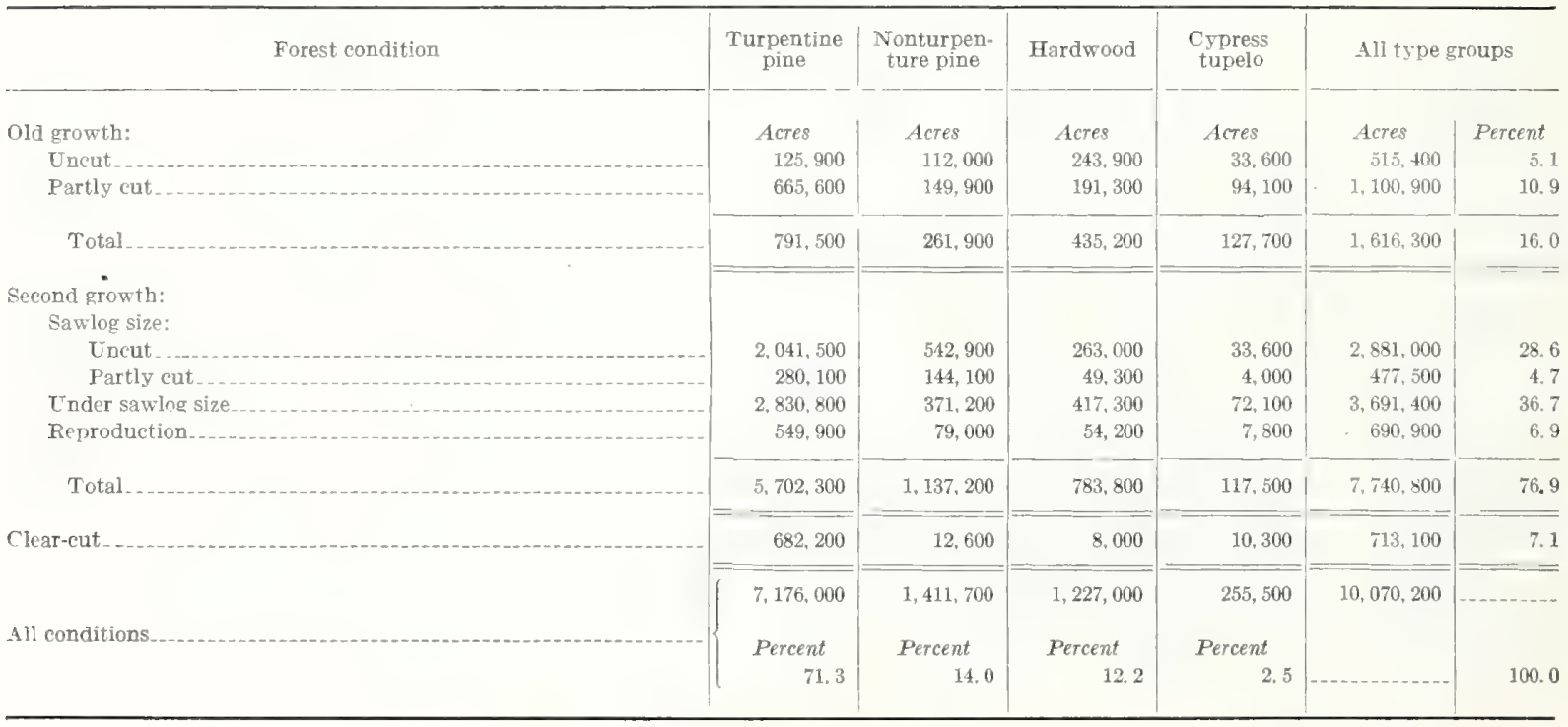


TABLE 5.-Average net board-foot volume, lumber tally, per acre by species-groups, forest type groups, and forest conditions, 1934 I

\begin{tabular}{|c|c|c|c|c|c|c|}
\hline \multirow{2}{*}{ Forest type and species group } & \multicolumn{2}{|c|}{ Old growth } & \multicolumn{2}{|c|}{$\begin{array}{l}\text { Second growth, sawlog } \\
\text { size }\end{array}$} & \multirow{2}{*}{$\begin{array}{l}\text { Second, } \\
\text { growth, } \\
\text { under } \\
\text { sawlog } \\
\text { size } 1\end{array}$} & \multirow{2}{*}{$\begin{array}{l}\text { All condi- } \\
\text { tions } 1\end{array}$} \\
\hline & Uncut & Partly cut & Uncut & Partly cut & & \\
\hline \multicolumn{7}{|l|}{ Turpentine pine types: } \\
\hline Turpentine pines: & Board feet & Board feet & Board feet & Board feet & Board feet & Board feet \\
\hline Round & 1,856 & 488 & 561 & 367 & 75 & 339 \\
\hline Worked & 2,836 & 2,166 & 1,466 & 1,203 & 210 & 963 \\
\hline Nonturpentine pines & 347 & 156 & 226 & 331 & 30 & 132 \\
\hline Soft-textured hardwoods & 235 & $2 n 2$ & 95 & 200 & 3 & 71 \\
\hline Firm-textured hardwoods. & 25 & 18 & 15 & 22 & 2 & 10 \\
\hline Cypress _................... & 433 & 214 & 76 & 124 & 16 & 73 \\
\hline All species. . . & 5,732 & 3,244 & 2,439 & 2,247 & 336 & 1. 588 \\
\hline \multicolumn{7}{|l|}{ Nonturpentine pine types: } \\
\hline Turpentine pines & 189 & 255 & 267 & 145 & 41 & 182 \\
\hline Nonturpentine pines...... & 5,942 & 2,635 & 3,583 & 2,380 & 338 & 2,632 \\
\hline Soft-textured hardwoods... & 903 & 717 & 303 & 436 & 37 & 341 \\
\hline Firm-textured hardwoods... & 608 & 316 & 237 & 248 & 38 & 223 \\
\hline Cypress _... & 135 & 34 & 34 & 2 & 3 & 30 \\
\hline All species........... & 7,777 & 3,957 & 4,424 & 3,211 & 457 & 3,408 \\
\hline \multicolumn{7}{|l|}{ Hardwood types: } \\
\hline Pines & 130 & 129 & 221 & 77 & 48 & 119 \\
\hline Soft-textured hardwoods & 4,612 & 2,705 & 2,226 & 1,248 & 107 & 2,004 \\
\hline Firm-textured hardwoods & 2,526 & 1,316 & 770 & 671 & 47 & 964 \\
\hline Cypress ............... & 250 & 196 & 124 & 142 & 15 & 124 \\
\hline All species........ . . . & 7,518 & 4,346 & 3,341 & 2,138 & 217 & 3. 211 \\
\hline \multicolumn{7}{|l|}{ Cypress types: } \\
\hline Pines . . . & 375 & 138 & 182 & & 25 & 141 \\
\hline Soft-textured hardwoods .... & 1,583 & 876 & 1,589 & & 15 & 801 \\
\hline Firm-textured hardwoods....... & 348 & 164 & 223 & & & 146 \\
\hline Cypress & 2,759 & 2.328 & 2,125 & 2,625 & 187 & 1,715 \\
\hline All speries... & 5,065 & 3,506 & 4,119 & 2,625 & 227 & 2,803 \\
\hline \multicolumn{7}{|l|}{ All types: } \\
\hline Round & 504 & 320 & 427 & 240 & 62 & 252 \\
\hline Worked & 700 & 1,340 & 1,068 & 727 & 165 & 678 \\
\hline Nonturpentine pines........ & 1,446 & 467 & 849 & 918 & 59 & 503 \\
\hline Soft-textured hardwoods & 2,539 & 764 & 347 & 378 & 19 & 392 \\
\hline Firm-textured hardwoods & 1,356 & 297 & 128 & 157 & 10 & 174 \\
\hline Cypress ....................... & 433 & 367 & 96 & 110 & 18 & 118 \\
\hline All species_._. & 6,978 & 3,555 & 2,915 & 2,530 & 333 & 22,117 \\
\hline
\end{tabular}

1 Does not include areas in reproduction and clear-cut conditions.

${ }_{2}^{2}$ If the reproduction and clear-cut conditions were included, the weighted average for all species in all conditions would be 1,839 board feet per acre.

46 percent is in the pine types. With the exception of a few areas, including several private hunting estates, old-growth timber is found in small scattered tracts that, because of ownership or location, have thus far escaped the wholesale liquidation to which these old-growth forests have been subjected during the last 60 years. Forty-seven percent of the area in uncut old-growth stands is in hardwood forests. These stands also are generally small and scattered along the river bottoms and in swamps and bays.
Partly cut areas of old-growth pine, hardwood, and cypress average about 3,600 board feet or 14 cords per acre, and are found scattered over the area. Over half of the partly cut old-growth area is occupied by longleaf and slash pine types, and has been, or is being, worked for turpentine.

Second-growth stands, chiefly turpentine pines, occupy nearly $73 / 4$ million acres, or 77 percent, of the forest area. Approximately 43 percent, or almost $3 \frac{1}{2}$ million acres, of the second growth is of saw timber size, the uncut portion averaging about 
2,900 board feet, or about 14 cords, per acre. Forty-eight percent of the second-growth area, or more than $3 \frac{3}{4}$ million acres, is occupied by undersawlog-size stands, a typical view of which is shown in figure 6. Although less than three-quarters of a million acres, or 9 percent, of the second-growth area was classified as reproduction, much of the forest area in old growth and in older stands of second growth has a good admixture or understory of pine or hardwood reproduction.
The density and distribution of seedlings in the reproduction areas vary greatly, but approximately 17 percent of that classified as slash pine reproduction and 7 percent of the longleaf pine reproduction is well stocked with more than 900 well-distributed seedlings per acre. An additional 21 percent of the slash and 15 percent of the longleaf reproduction area has 170 to 900 well-distributed seedlings per acre. On approximately 11 percent of the reproduction area in slash and longleaf, the stand of

TABLE 6.-Average net cordwood volume (outside bark) of sound trees ${ }^{1}$ per acre by species groups, forest type groups, and forest conditions, ${ }^{2} 1934$

\begin{tabular}{|c|c|c|c|c|c|c|}
\hline \multirow{2}{*}{ Forest type and species group } & \multicolumn{2}{|c|}{ Old growth } & \multicolumn{2}{|c|}{$\begin{array}{c}\text { Second growth, sawlog } \\
\text { size }\end{array}$} & \multirow{2}{*}{$\begin{array}{l}\text { Second } \\
\text { growth, } \\
\text { under saw- } \\
\text { log size } 2\end{array}$} & \multirow{2}{*}{$\begin{array}{l}\text { All con- } \\
\text { ditions }{ }^{2}\end{array}$} \\
\hline & Uncut & Partly cut & Uncut & Partly cut & & \\
\hline \multicolumn{7}{|l|}{ Turpentine fine types: } \\
\hline Turpentine pines: & Cords & Cords & Cords & Cords & Cords & Cords \\
\hline 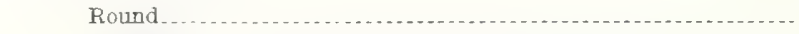 & 5.7 & 2.1 & 3.7 & 2.5 & 1.7 & 2.5 \\
\hline Worked $\ldots \ldots \ldots \ldots$ & 8.4 & 6.6 & 6. 3 & 5.3 & 1.4 & 4,0 \\
\hline Nonturpentine pines & 1.0 & .5 & .7 & 1.1 & .2 & .5 \\
\hline Soft-textured hardwoods & 2.7 & 1.8 & 1.4 & 2.7 & .1 & .9 \\
\hline Firm-textured hardwoods ................ & .4 & .1 & .1 & .3 & .1 & .1 \\
\hline 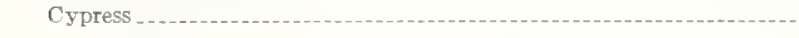 & 1.8 & 1. 0 & -4 & .6 & .1 & .4 \\
\hline All species ...- & 20.0 & 12. 1 & 12. 6 & 12.5 & 3.6 & 8.4 \\
\hline \multicolumn{7}{|l|}{ Nonturpentine pine types: } \\
\hline Turpentine pine & .6 & .9 & 1.1 & .6 & .3 & .8 \\
\hline Nonturpentine pine & 14.6 & 7.0 & 11.1 & 7.6 & 2.5 & 8.1 \\
\hline Soft-textured hardwoods $\ldots$ & 4.4 & 5.1 & 2.8 & 3.2 & .7 & 2. 6 \\
\hline Firm-textured hardwoods ..... & 2,6 & 1.5 & 1.5 & 1.5 & .5 & 1.3 \\
\hline Cypress & .3 & .1 & 1 & (3) & $(3)$ & .1 \\
\hline All species... & 22.5 & 14.6 & 16. 6 & 12.9 & 4.0 & 12.9 \\
\hline \multicolumn{7}{|l|}{ Hardwood types: } \\
\hline 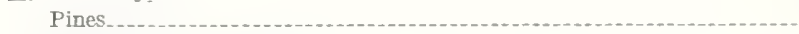 & .4 & .4 & .7 & .4 & .2 & .4 \\
\hline Soft-textured hardwoods & 17.7 & 12.1 & 14.0 & 10.5 & 2.1 & 10.1 \\
\hline Firm-textured hardwoods ... & 8.4 & 5.2 & 3.8 & 3.4 & .7 & 3.8 \\
\hline Cypress . . & .7 & .5 & -4 & .4 & .1 & .4 \\
\hline All species...- & 27.2 & 18.2 & 18.9 & 14.7 & 3.1 & 14.7 \\
\hline \multicolumn{7}{|l|}{ Cypress types: } \\
\hline Pines_... & 1.1 & .6 & .6 & $-\ldots$ & .1 & .5 \\
\hline Soft-textured hardwoods.... & 9.6 & 8. 3 & 14.1 & 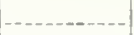 & 2,1 & 7.3 \\
\hline Firm-textured hardwoods..... & 1.6 & .8 & 2.3 & & .1 & .9 \\
\hline 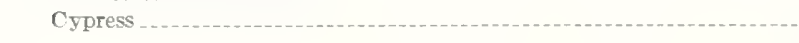 & 8.8 & 8.2 & 7.5 & 13.4 & 2.6 & 6.5 \\
\hline All species........ & 21.1 & 17.9 & 24.5 & 13.4 & 4.9 & 15.2 \\
\hline \multicolumn{7}{|l|}{ All types: } \\
\hline Round................ & 1.5 & 1.4 & 2.8 & 1.6 & 1.3 & 1.8 \\
\hline Worked & 2.1 & 4. 0 & 4.6 & 3.1 & 1.1 & 2.8 \\
\hline Nonturpentine pines. & 3.6 & 1.3 & 2.7 & 3.0 & .4 & 1.6 \\
\hline Soft-textured hardwoods & 10.7 & 4. 6 & 2.9 & 3.6 & .4 & 2.6 \\
\hline Firm-textured hardwoods.... & 4.7 & 1.3 & .7 & 1.0 & .2 & .8 \\
\hline Cypress ........... & 1.4 & 1.4 & .4 & .5 & .2 & .5 \\
\hline All species & 24.0 & 14.0 & 14.1 & 12.8 & 3. 6 & 410.1 \\
\hline
\end{tabular}

${ }^{1}$ Includes all sound material in trees 5.0 inches d. b. h. and larger, exclusive of cull trees and the top stems and limbs of hardwoods and cypress.

2 Does not include areas in reproduction and clear-cut conditions.

${ }^{3}$ Negligible.

${ }^{4}$ If the reproduction and clear-cut conditions were included, the weighted-average volume per acre would be 8.8 cords. 


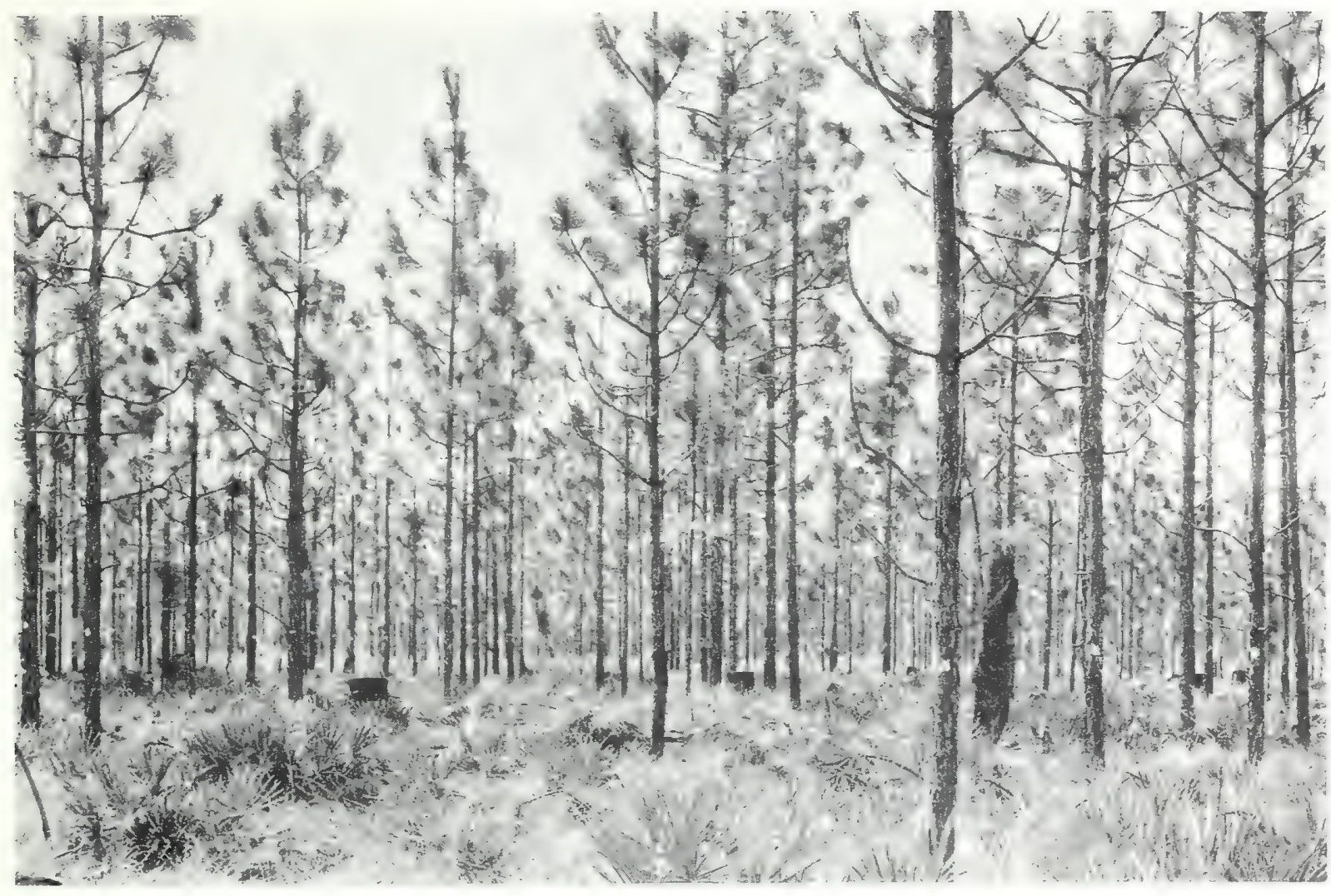

Figure 6.-Typical stand of round, second-growth, under-sawlog-size longleaf pine.

seedlings is fair (300 or more), but they are poorly distributed - often in dense groups with open spaces between. The remainder has a minimum stocking of 80 seedlings per acre, often poorly distributed. Hog damage to longleaf pine seedlings, which was recorded on approximately 10 percent of the turpentine pine area, is widespread but patchy, being significant only where hog grazing is concentrated.

Approximately 18 percent of the area where longleaf pine seedlings occurred was moderately to heavily infected with brown spot fungus, a disease adversely affecting longleaf seedlings; the remaining 82 percent had either light or no infection.

On land classified as "clear-cut," aggregating almost three-quarters of a million acres, the occurrence of seed trees is an important factor in restocking. Of the clear-cut area in the pine group (694,800 acres), 12 percent had no seed trees and will require planting if restocking at an early date is to be accomplished. An additional 26 percent had but 1 or 2 seed trees per acre and will be slow to restock. The remaining 62 percent supports 3 or more seed trees per acre, and these, with the aid of fire protection, should restock the area naturally. Loblolly and slash pines are prolific seeders and with protection from fire can be expected rapidly to restock adjacent cut-over areas.

\section{Stocking of Forest Stands}

The forest stands of south Georgia consist chiefly of small, young second-growth trees, as may be seen by the stand diagrams (figs. 7 and 8), which show for the entire forest area the number of sound trees by diameter classes in the several species groups. More than 48 percent of all trees on the area are in the 2-inch diameter class. Only 20 percent are 7.0 inches d. b. h. or Iarger. About 88 percent of the round turpentine pines, which make up a large part of the pine stocking, are in the smalldiameter classes, i. e., are less than 7.0 inches d. b. h. Largely owing to the fact that gum naval stores operations have followed the practice of beginning chipping with trees in the 8-inch diameter class, 


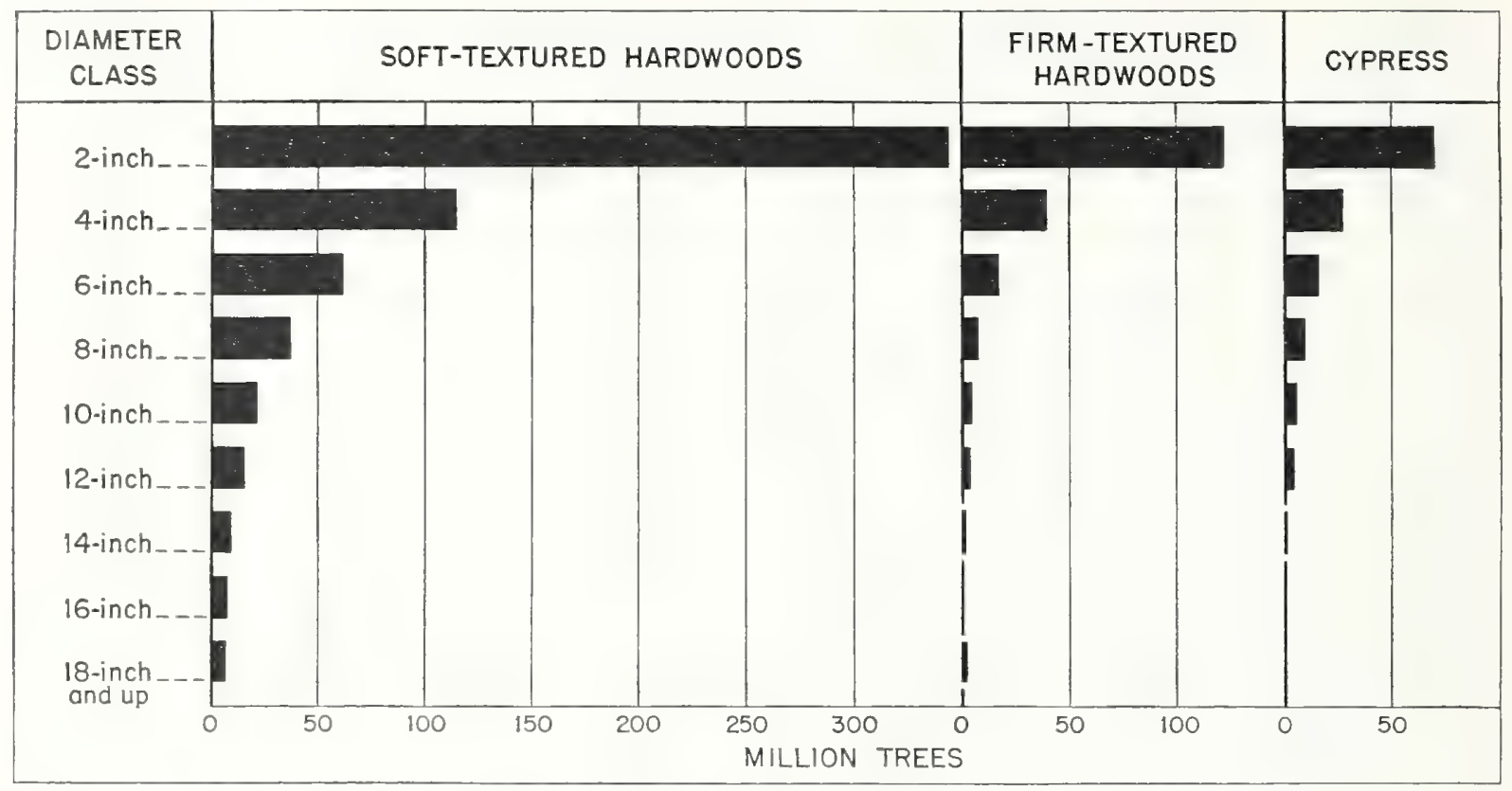

Figure 7.-Stand diagram for hardwoods and cypress.

only 12 percent of the round trees are 7.0 inches d. b. h. or larger, and only 4 percent are at least 9.0 inches d. b. h.

There are enough trees in the smaller diameter classes to increase materially the growing stock of timber during the years to come, provided they continue to grow. Owing to fires, natural crowding, turpentining, and other agencies, however, the small trees that reach merchantable size are only a part of the original number. Where adequate protection from fire has been given for a few years, open areas with seed trees usually have restocked

\begin{tabular}{|l|l|l|l|l|l|l|}
\hline $\begin{array}{c}\text { DIAMETER } \\
\text { CLASS }\end{array}$ & \multicolumn{3}{|c|}{ ROUND TURPENTINE PINES } & $\begin{array}{c}\text { TURPENTINED } \\
\text { PINES }\end{array}$ & $\begin{array}{c}\text { NONTURPENTINE } \\
\text { PINES }\end{array}$ \\
\hline & & & & & \\
\hline \\
2-inch
\end{tabular}

Figure 8.-Stand diagram for pines. 
Figure 9.-Distribution by area of prevailing age classes and volume, compared with the volume in well-stocked stands (most heavily stocked 10 percent of the stands). Based on turpentine pine type area of $7,176,000$ acres. Measurements are inside bark, on growingstock trees 5 inches $d . b . h$. or larger. On the well-stocked area each age class occupies approximately 14.3 percent of the area.

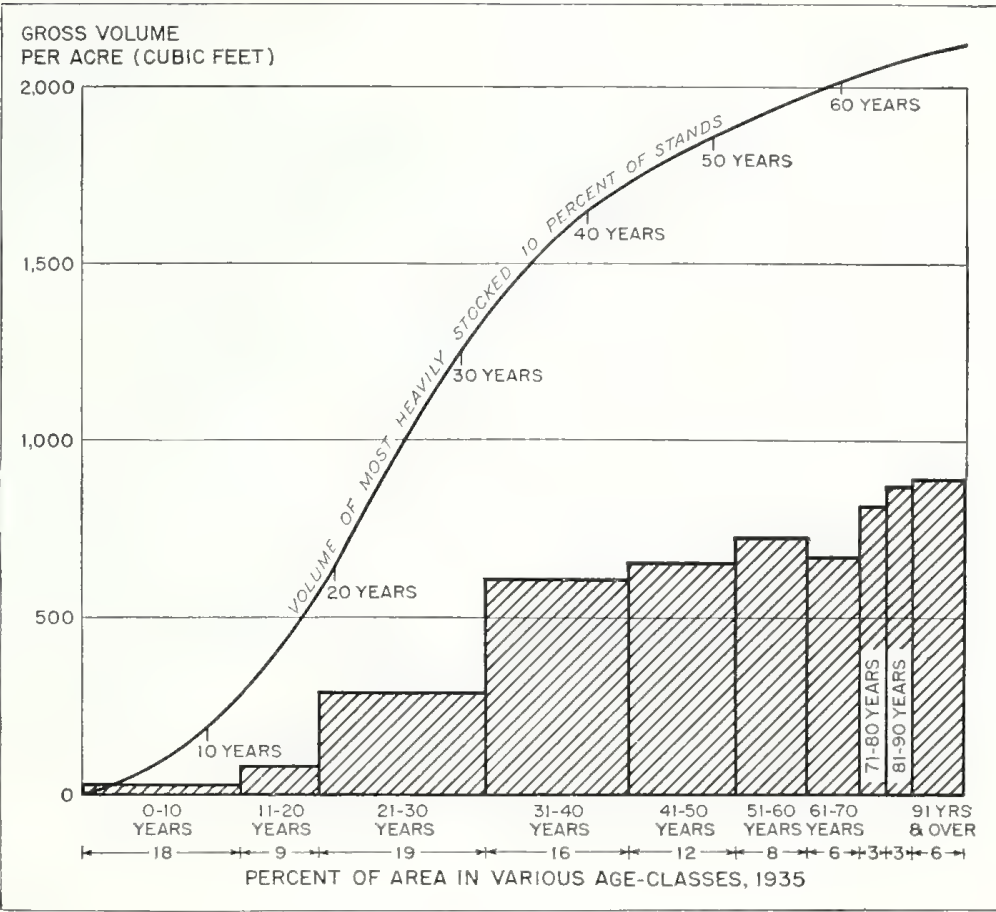

satisfactorily. These practical examples, together with effective educational programs and widely broadened markets for forest products, have caused many landowners to realize the damaging effect of fire and the increasing value of well-stocked forest lands. There is at present, therefore, a widespread trend towards better fire protection, improved turpentining practices, and better forest management, which should increase the quantity and improve the quality of the growing stock and its annual increment of usable material.

To give an idea of the adequacy of the present turpentine pine forest, distribution of its area and average volume per acre by age class has been compared in figure 9 with those of a well-stocked forest of equal area on 70-year rotation.

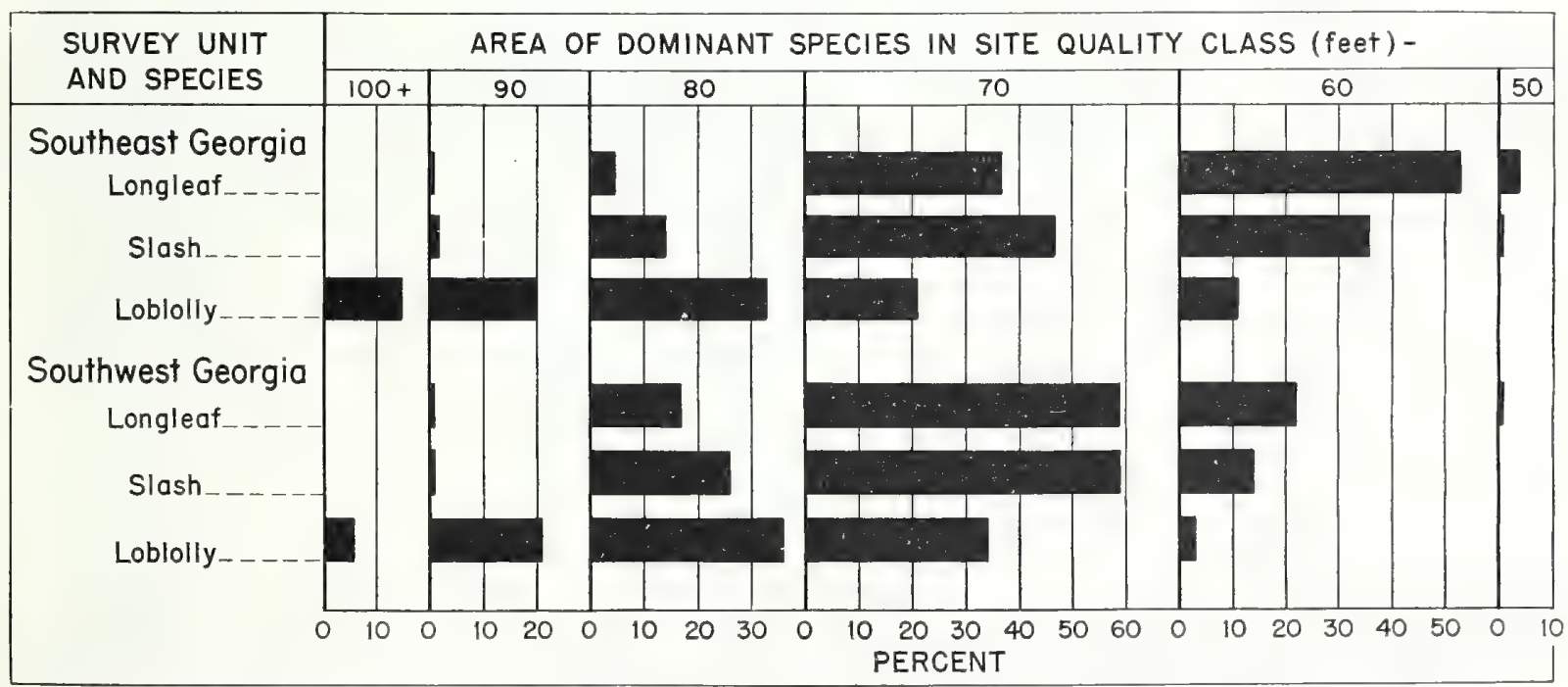

FIGURE 10.- Percent of area dominated by the principal pine species, classified according to site quality (based on height at 50 years), southeast and southwest Georgia. 


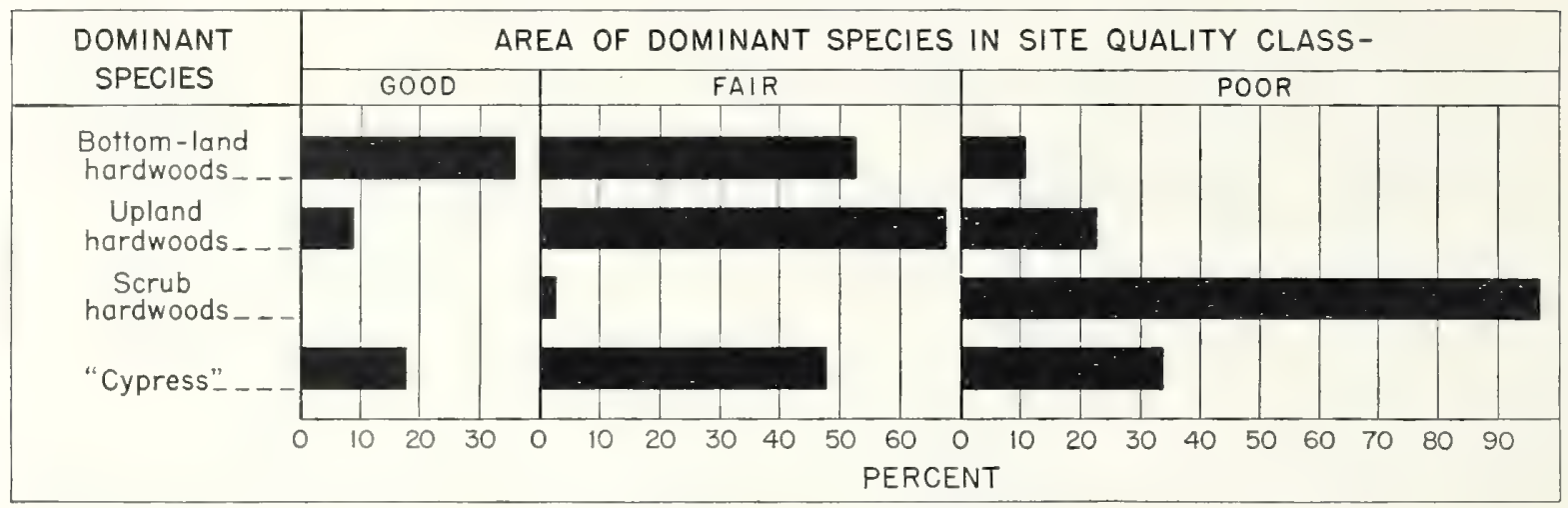

Figure 11.-Percent of area dominated by hardwoods and cypress, classified according to site quality, south Georgia.

The volume figures are gross; no deductions for woods cull, which would be negligible in a managed forest, have been made, and as an equalizing factor, no volumes in turpentined butts have been included. The per-acre volumes used as representing the well-stocked forest are the average of the heaviest stocked 10 percent of the present uncut forest stands for weighted-average sites in the turpentine pine types. These indicate what is attainable under better forest practice.

The comparison discloses that the present stand is sadly deficient in that it has only about onethird the volume, age class for age class, of the well-stocked stands. The areas in the younger age classes (10 to 60 years) are fairly well proportioned.

\section{Site Quality}

The variable factors of soil, drainage, exposure, topography, and climate affect the growth and quality of timber stands. The combined effect is indicated in the term "site quality." In the survey, sites occupied by the pine species were graded into site-quality classes, based upon the total height attained by dominant and codominant trees at 50 years of age (fig. 10). Longleaf pine, which is adaptable to the poorer sites where the stand is usually open, in south Georgia averaged only 66 feet in height at 50 years of age. Slash pine, which occurred on slightly better sites, averaged 69 feet; while loblolly pine which generally grows on much

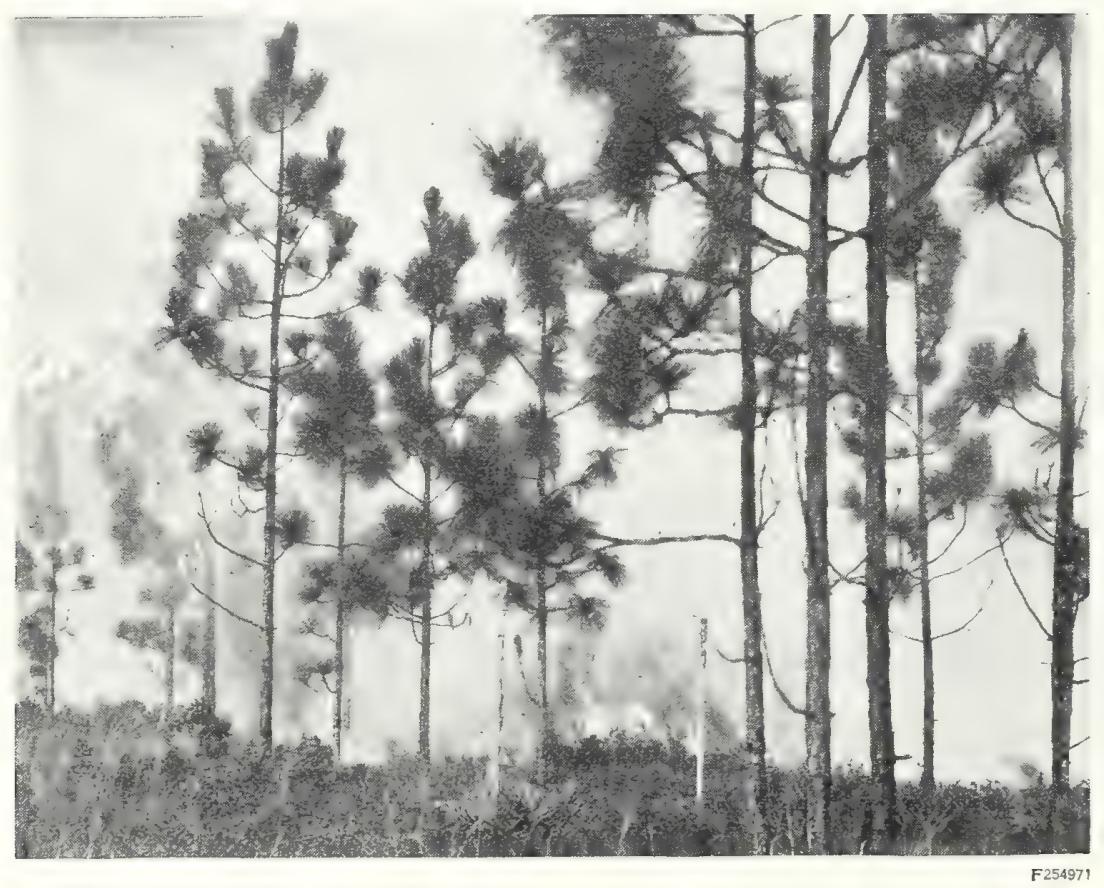

Figure 12.-Fire is the most serious menace to the future of forestry in south Georgia. This fire is burning through a stand of 19-year-old longleaf pine that had been protected for 6 years. 


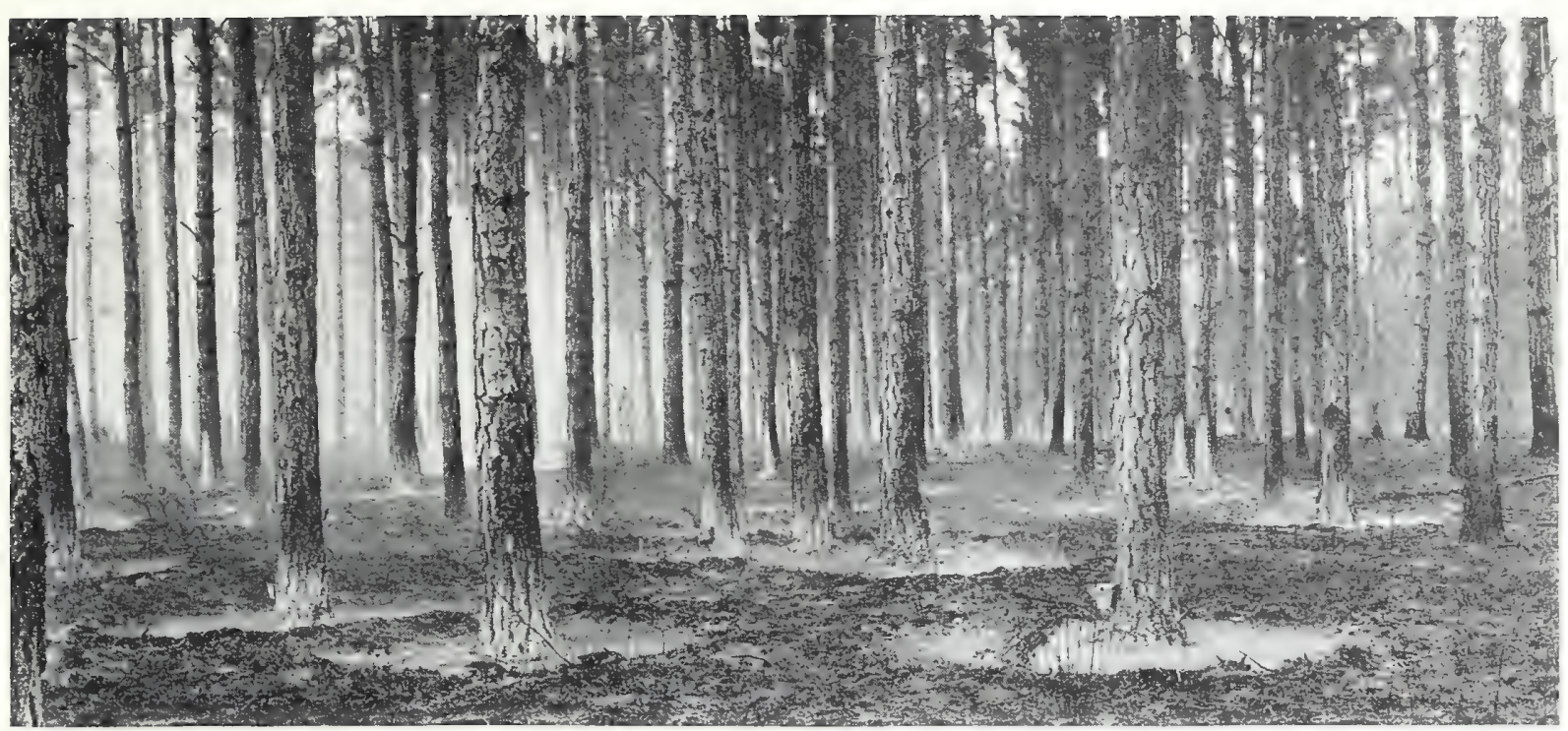

F 254592

FIGURE 13. - Second-growth sawlog-size slash pine with virgin turpentine faces. The inflammable material has been raked from the base of each tree, and the area has been burned by a light, controlled fire.

better sites than either slash or longleaf pine, averaged 80 feet in height. As shown by figure 10, a greater proportion of longleaf and slash pine is on higher quality sites in southwest than in southeast Georgia. Hardwood and cypress sites were graded into three general quality classes on the basis of tree form and clear length. These were distributed in roughly the same proportions in each of the two survey units here discussed, and are shown as one in figure 11.

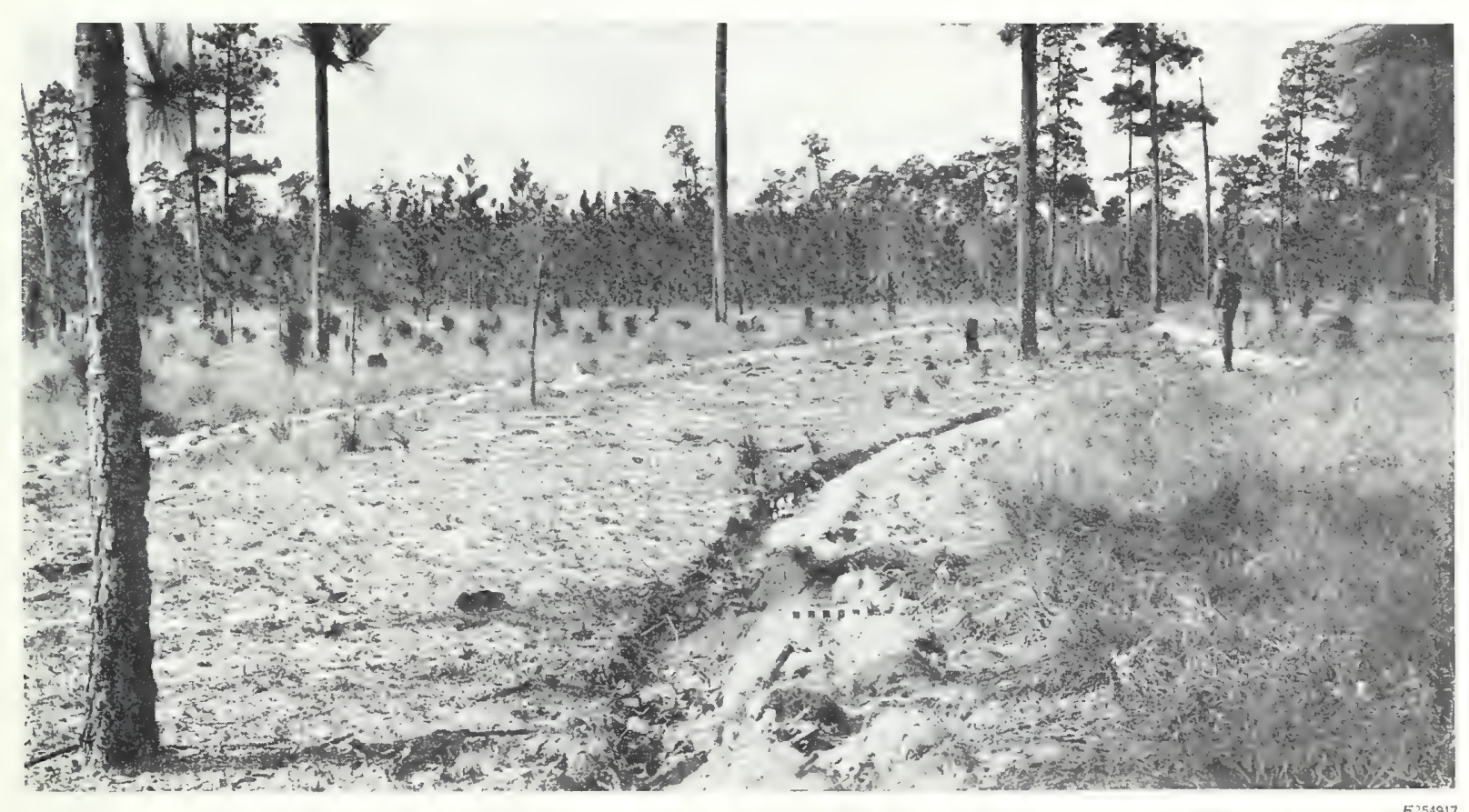

FIGURE 14.-Plowed and burned firebreaks protect much of the timber of south Georgia from fires. 


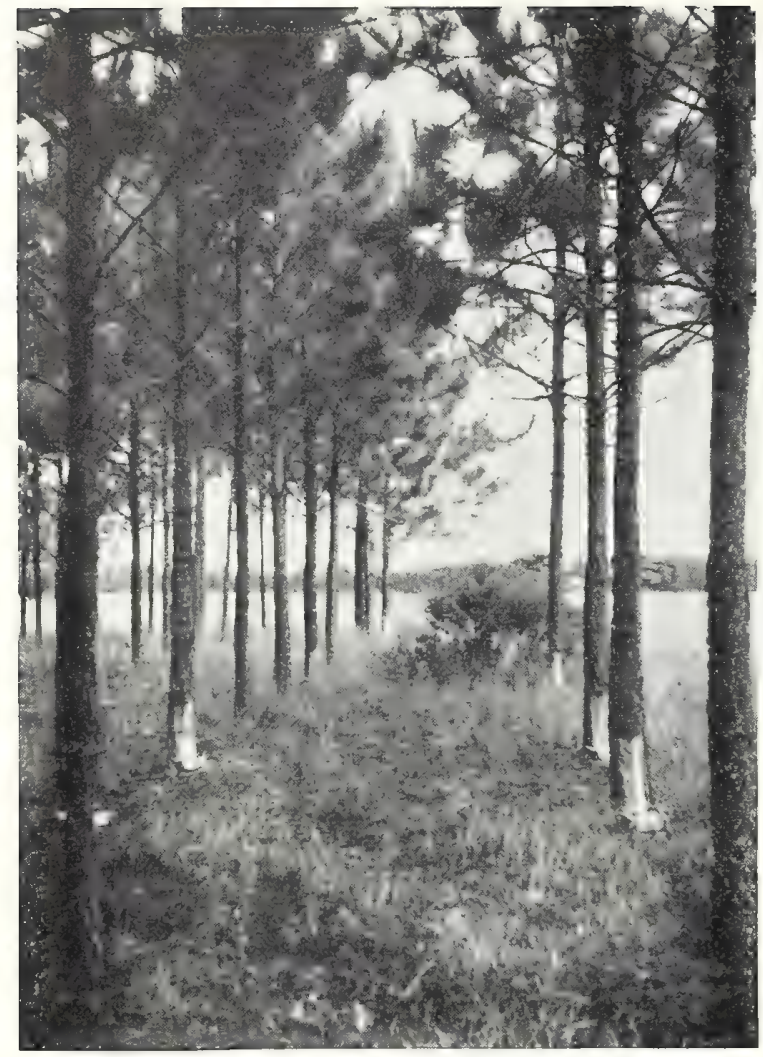

FIGURE 15.-This 11-year-old plantation, which exemplifies the fast-growing properties of slash pine in south Georgia, is now being worked experimentally for naval stores.

\section{Fire Damage}

Since early settlement days the forests of south Georgia have been subjected to widespread and repeated forest fires. Evidence of fires was found by the Forest Survey on 90 percent of the forest area in the turpentine pine group, on 80 percent in the nonturpentine pine group, and on 50 percent of the hardwood area (fig. 12). In the naval stores woods it has been customary to rake all inflammable material from the base of trees being worked for gum and to burn the area in the winter (fig. 13). Although this procedure protects the cupped trees during the period of operations, it is decidedly detrimental to the stand as a whole, and repeated forest burning has a deleterious effect on the density, the growth rate, and the quality of the stand.

The Georgia State Forest Service was organized in 1926, and immediately attacked the serious fire problem, with the cooperation of the Federal Government. Much progress has been made in educating landowners and the public generally as to the detrimental effects of woods burning and in organizing forest-fire protection. In 1938 approximately 1,500 landowners, in cooperation with the State and Federal Governments, were applying systematic fire protection on more than $2 \frac{1}{3}$ million acres, or about one-fourth of the forest land of south Georgia (fig. 14).

During the last few years a much saner and healthier public attitude has developed in support of landowners and public agencies in their efforts to stamp out wholesale woods burning and to practice good forestry. Many private individuals and companies are not only protecting their holdings but are also thinning overdense stands, making improvement cuttings, and planting up open areas. In the spring of 1937 alone, almost $21 / 2$ million slash and longleaf seedlings were planted on numerous areas throughout south Georgia. Some of these plantations are experimental only but others are large commercial ventures involving several thousand acres. (fig. 15). 


\section{Naval Stores}

\section{$\mathrm{T}$} HE history of the gum naval stores industry goes back to the days of wooden sailing ships, when the tar and pitch extracted from the resinous pines of New England were used in the construction and repair of wooden navy and merchantmarine vessels. The commodity thus derived its name-naval stores. When it was discovered that the yield of turpentine and rosin from slash and longleaf pines was far greater than that from the northern species of pine and that the southern pines were easier and cheaper to work, the industry shifted to the South and became one of the leading branches of agriculture.

Georgia assumed the leadership in production late in the ninteenth century, with Savannah as the principal export, marketing, and financial center of the industry, and retained it until shortly before 1905, when Florida assumed the leadership and developed a separate marketing center at Jacksonville. The favorable prices of turpentine and rosin immediately after the World War, together with the more general adoption of improved naval stores woods practices, made possible the utilization of much smaller and younger second-growth timber; and in 1923 Georgia again assumed the lead (fig. 16).

The naval stores industry of south Georgia has two important branches: (1) The gum naval stores branch, which uses gum extracted from live trees; and (2) the wood naval stores branch, which uses seasoned stumps and lightwood. In 1936, there was no recovery of sulfate turpentine or liquid rosin as a byproduct of the pulp and paper industry in south Georgia, but with the development of this practice and the construction of new kraft mills, this phase of the industry also may become important.

\section{Gum Naval Stores Industry}

In 1933-34 this important industry worked 6,700 crops in south Georgia, produced approximately 287,000 naval stores units ${ }^{4}$ valued at more than $\$ 13,000,000$, and furnished employment in the

4 A crop consists of 10,000 faces. A naval stores unit is made up of one 50-gallon barrel of turpentine and three and one-third 500-pound (gross) barrels of rosin.

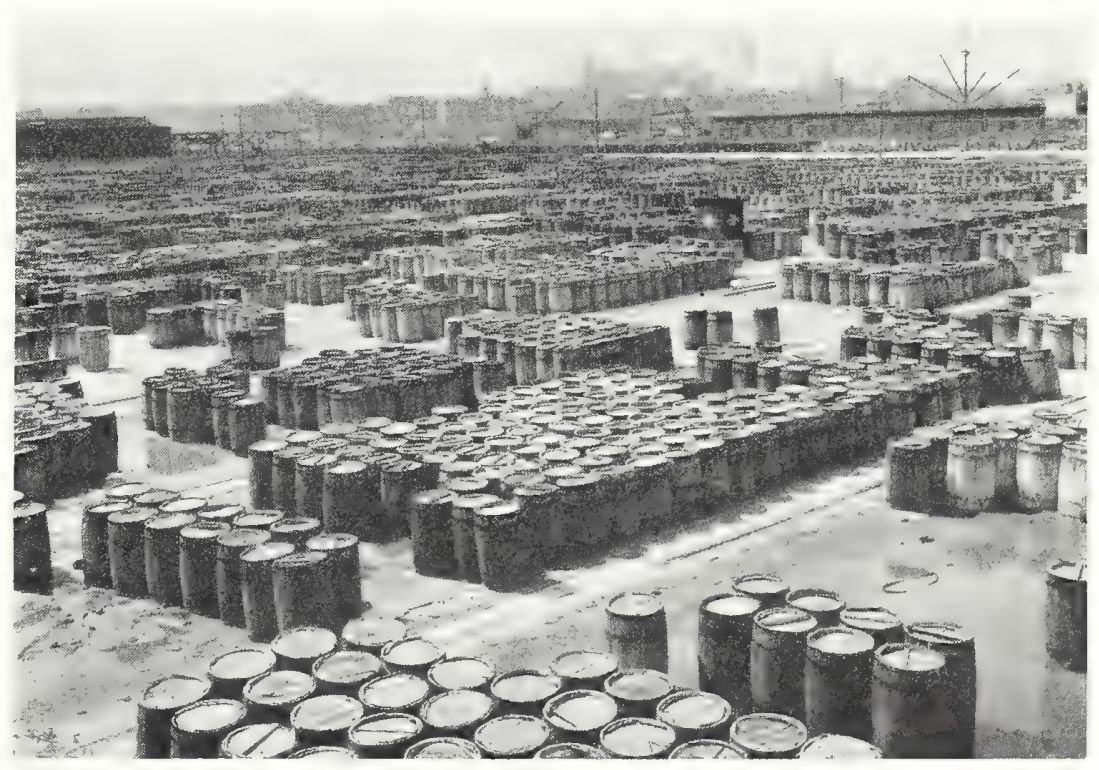

FIGURE 16.-Rosin storage yard, Savannah, Ga., the financial and marketing center of the naval stores industry. 


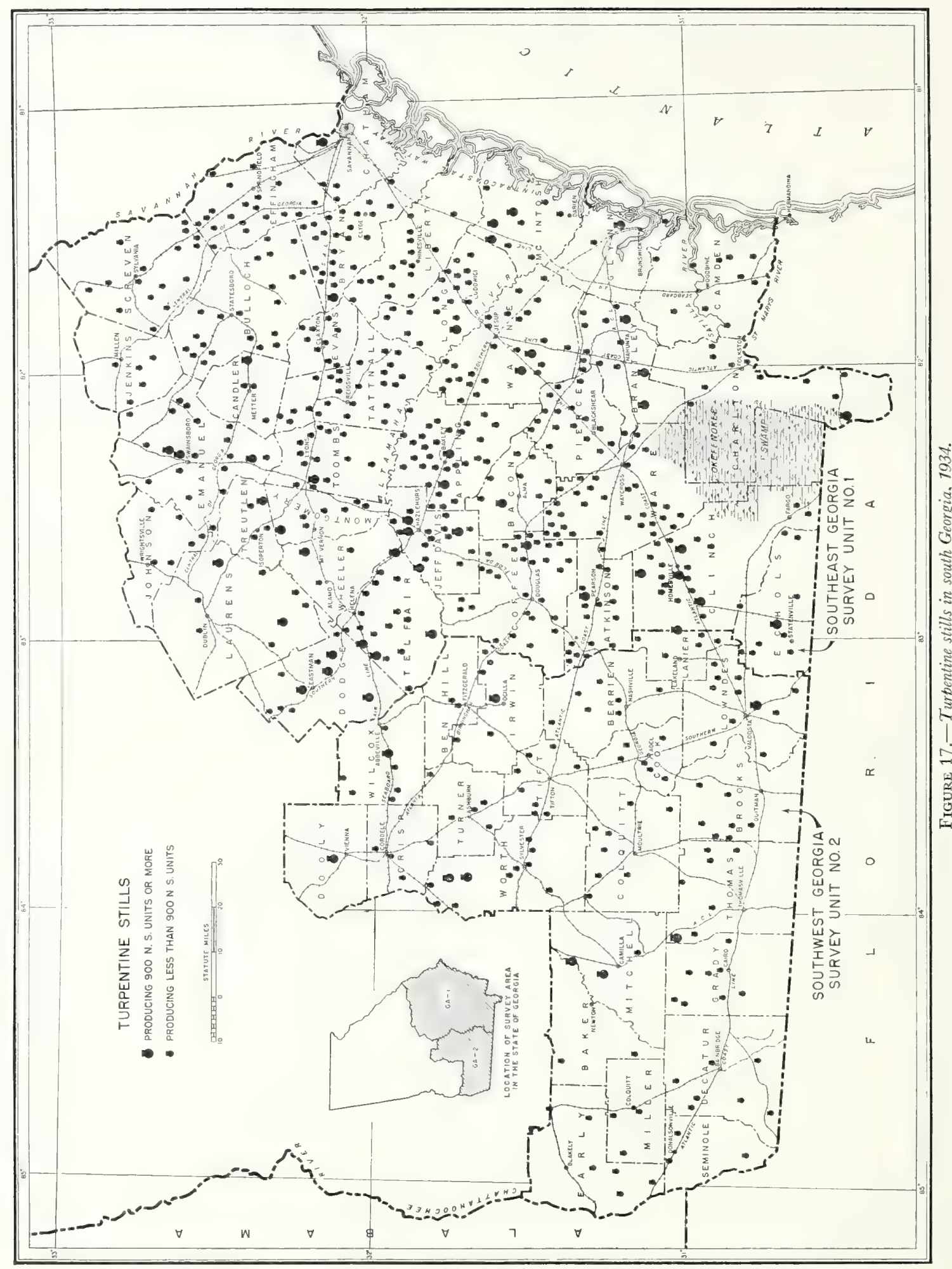


woods and at the stills for approximately 25,000 people.

The number of crops increased during the 193435 season to 7,064 , with an estimated production of approximately 300,000 units having a total value of more than $\$ 15,000,000$. During the 1935-36 season, production dropped to approximately 285,000 units with a total value of less than $\$ 14,000,000$. Although production dropped still more to approximately 272,000 units in 1936-37, the more favorable price per unit increased the value to approximately $\$ 16,500,000$.

Seven factorage houses in south Georgia and north Florida control a large portion of the production in this region, advancing credit to turpentine operators, furnishing commissary supplies and equipment, and acting as commission merchants in the disposal of turpentine and rosin.

In 1934-35 there were 635 active still operations in south Georgia- 54 percent of the total for the naval stores region. (Fig. 17.) These were distributed according to production in that year as follows:

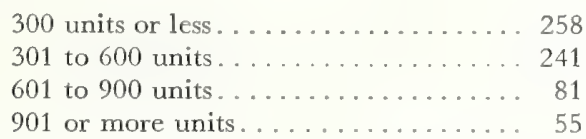

There were in addition approximately 10,000 gum producers without stills, making up 80 percent of the producers in this class in the entire naval stores region. As large and well-blocked areas of available naval stores timber become increasingly scarce and a ready cash market for gum is estab- lished by modern and efficient central stills and gum-cleaning plants, the small operators who can work more isolated and scattered trees are becoming more important. While the number of large processors with stills increased slightly during the 1934-35 season, there is reason to believe that the number of small gum producers increased by approximately 1,000 over the previous season.

\section{Gum Naval Stores Resources}

Approximately 8 million acres, or 79 percent of the forest land, was classified as turpentine land (table 7). The gross area includes some intermingled clear-cut and reproduction lands as well as some nonturpentine pine and hardwood.

Of the total turpentine area, 43 percent (fig. 18) was in well-developed turpentine stands in 1934. These average 23 possible faces per acre on resting, working, or round trees at least 9 inches d. b. h. (assuming 1 face for each round tree), and have a minimum of 8 faces per acre. Eleven percent of the area is in advanced sapling stands, which have enough round trees, largely in the 8 -inch diameter class, to indicate that the stands will be well developed in the next 8 years; 15 percent is in young sapling stands made up chiefly of 2-, 4-, and 6-inch trees that will require about 15 years to reach the well-developed status; and 27 percent is in reproduction and clear-cut stands that will require over 20 years to reach a stage favorable for turpentine operation. Approximately 4 percent is in intermingled nonturpentine areas.

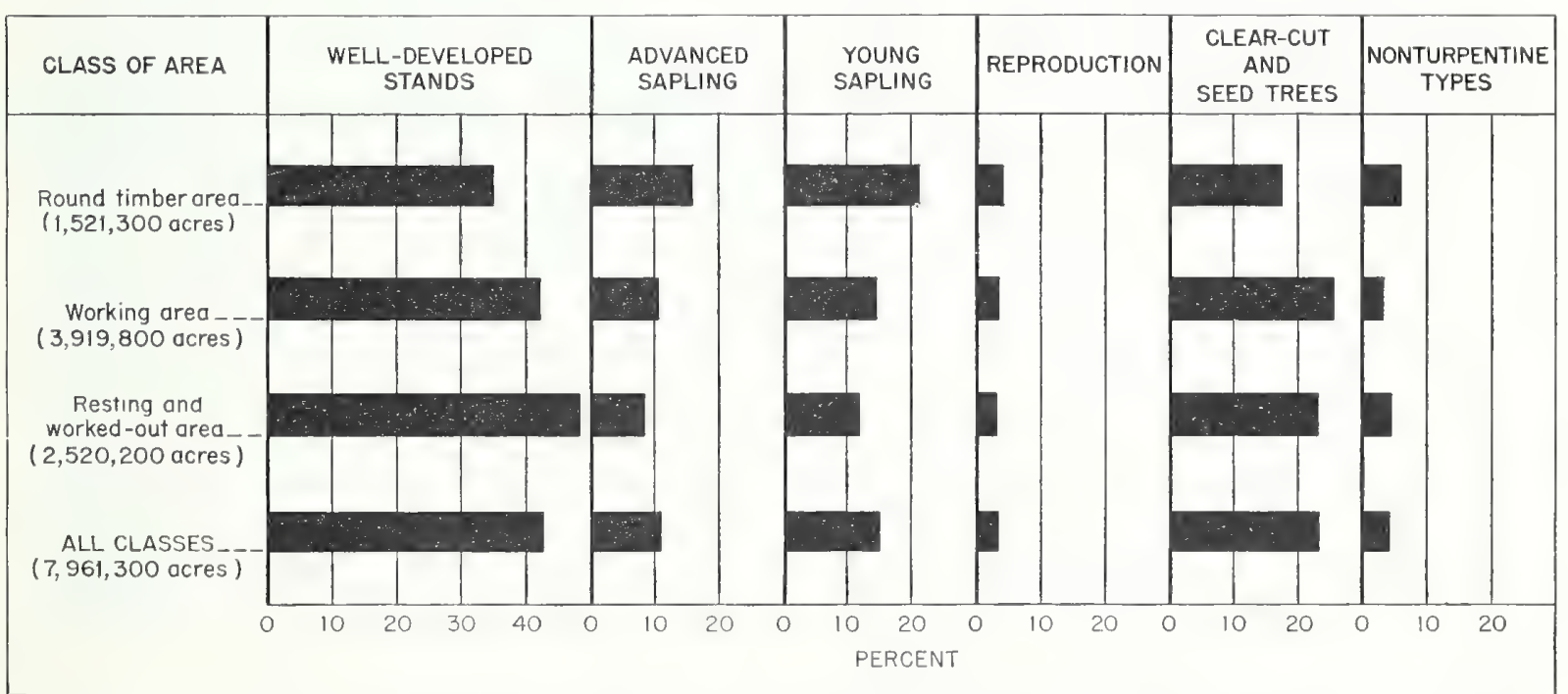

FIGURE 18. - Distribution of areas in each turpentining class, and in all classes, with respect to kind of timber, south Georgia, 1934. 
TABLE 7.-Classification of turpentine area according to crop history and topographic situation in the 1934-35 season

\begin{tabular}{|c|c|c|c|c|c|c|}
\hline Turpentine history & Flatwoeds & $\begin{array}{l}\text { Rolling } \\
\text { uplands }\end{array}$ & $\begin{array}{c}\text { River } \\
\text { bottoms }\end{array}$ & $\begin{array}{l}\text { Swamps, } \\
\text { bays, etc. }\end{array}$ & \multicolumn{2}{|c|}{ All situations } \\
\hline Round-timber area & $\begin{array}{l}\text { Acres } \\
441,600\end{array}$ & $\begin{array}{l}\text { Acres } \\
748,800\end{array}$ & $\begin{array}{l}\text { Acres } \\
\quad 10,200\end{array}$ & $\begin{array}{l}\text { Acres } \\
320,700\end{array}$ & $\begin{array}{l}\text { Acres } \\
1,521,300\end{array}$ & $\begin{array}{r}\text { Percent } \\
\quad 19.1\end{array}$ \\
\hline Working area: & & & & & & \\
\hline Front-faced & 175,300 & 196,100 & 2,300 & 85,000 & 458,700 & 5.8 \\
\hline Back-faced & $1,441,100$ & $1,286,600$ & 11,000 & 722,400 & $3,461,100$ & 43.5 \\
\hline Worked-out and resting areas. & $1,013,100$ & 919,400 & 19,000 & 568,700 & $2,520,200$ & 31.6 \\
\hline Total turpentine area... & $3,071,100$ & $3,150,900$ & 42,500 & $1,696,800$ & $7,961,300$ & 100.0 \\
\hline Nonturpentine area. & 302,500 & 452,100 & 393,100 & 961,200 & $2,108,900$ & \\
\hline Total forest area... & $3,373,600$ & $3,603,000$ & 435,600 & $2,658,000$ & $10,070,200$ & \\
\hline
\end{tabular}

\section{Round-Timber Area}

Round-timber areas are those in which practically all the slash and longleaf pines from reproduction to old growth are unworked for naval stores and in sufficient quantities to justify working either now or at some future time. They occupy more than $1 \frac{1}{2}$ million acres, or 19 percent of the turpentine area, and constitute one of the main reserves of the future gum naval stores industry (table 7). Most of this area is within or adjacent to well-organized naval stores operations; the remainder is in small, isolated, scattered tracts.

More than a half million acres of the round tur- pentine area is in well-developed stands (fig. 17), averaging per acre 24 round trees at least 9 inches d. b. h., 16 trees in the 8-inch diameter class, and more than 70 smaller trees. An additional quarter of a million acres has an average of two 10-inch, fourteen 8-inch, and more than a hundred 2-, 4-, and 6-inch trees per acre, and will be ready for operation within a few years. On the remaining round-timber area, which includes the young sapling and reproduction stands, as well as the intermingled clear-cut and nonturpentine areas, the trees are too small or too scattered to warrant operation under present practices before 15 to 20 years.

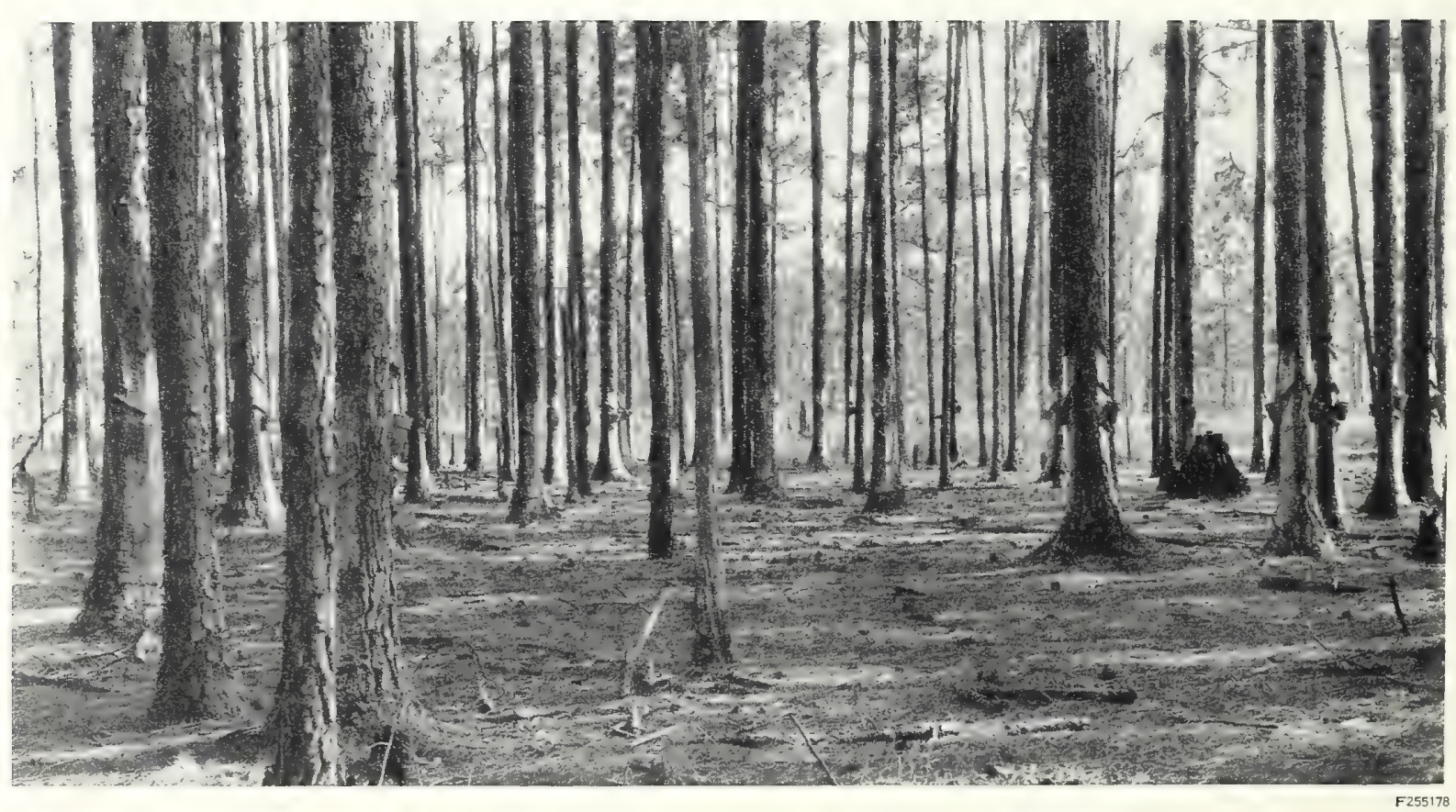

FIGURE 19.- Second-growth slash pine in dry pond being worked for naval stores. When worked out, this timber will produce good lumber. 
TABLE 8.-Turpentine operations during the 1934-35 season, by year of working

\begin{tabular}{|c|c|c|c|c|c|c|c|c|}
\hline Working area and manner of eupping & $\begin{array}{l}\text { First } \\
\text { year }\end{array}$ & $\begin{array}{l}\text { Second } \\
\text { year }\end{array}$ & $\begin{array}{l}\text { Third } \\
\text { year }\end{array}$ & $\begin{array}{l}\text { Fourth } \\
\text { year }\end{array}$ & $\begin{array}{l}\text { Fifth } \\
\text { year }\end{array}$ & $\begin{array}{l}\text { Sixth } \\
\text { year and } \\
\text { later }\end{array}$ & \multicolumn{2}{|c|}{ All years } \\
\hline $\begin{array}{l}\text { Front-face areas: } \\
\text { On front faces. } \\
\text { On back faces }\end{array}$ & $\begin{array}{r}\text { Crops } \\
194.0 \\
19.7\end{array}$ & $\begin{array}{r}\text { Crops } \\
276.5 \\
31.5\end{array}$ & $\begin{array}{r}\text { Crops } \\
61.1 \\
6.3\end{array}$ & $\begin{array}{r}\text { Crops } \\
105.5 \\
10.6\end{array}$ & $\begin{array}{r}\text { Crops } \\
139.6 \\
14.7\end{array}$ & $\begin{array}{l}\text { Crops } \\
104.5 \\
10.5\end{array}$ & $\begin{array}{l}\text { Crops } \\
881.2 \\
93.3\end{array}$ & $\begin{array}{r}\text { Percent } \\
12.5 \\
1.3\end{array}$ \\
\hline Total & 213.7 & 308.0 & 67.4 & 116.1 & 154.3 & 115.0 & 974.5 & 13.8 \\
\hline $\begin{array}{l}\text { Back-face areas: } \\
\text { On front faces } \\
\text { On back faces }\end{array}$ & $\begin{array}{l}493.6 \\
947.4\end{array}$ & $\begin{array}{l}933.0 \\
893.8\end{array}$ & $\begin{array}{l}248.0 \\
351.2\end{array}$ & $\begin{array}{l}221.1 \\
385.7\end{array}$ & $\begin{array}{l}385.9 \\
451.0\end{array}$ & $\begin{array}{l}373.9 \\
404.9\end{array}$ & $\begin{array}{l}2,655.5 \\
3.434 .0\end{array}$ & $\begin{array}{l}37.6 \\
48.6\end{array}$ \\
\hline Total & $1,441.0$ & $1,826.8$ & 599.2 & 606.8 & 836.9 & 778.8 & $6,089.5$ & 86.2 \\
\hline $\begin{array}{l}\text { All working areas: } \\
\text { On front faces... } \\
\text { On back faces }\end{array}$ & $\begin{array}{l}687.6 \\
967.1\end{array}$ & $\begin{array}{r}1,209.5 \\
925.3\end{array}$ & $\begin{array}{r}309.1 \\
357.5\end{array}$ & $\begin{array}{l}326.6 \\
396.3\end{array}$ & $\begin{array}{r}525.5 \\
465.7\end{array}$ & $\begin{array}{l}478.4 \\
415.4\end{array}$ & $\begin{array}{l}3,536.7 \\
3,527.3\end{array}$ & $\begin{array}{l}50.1 \\
49.9\end{array}$ \\
\hline Total & $\begin{array}{r}1,654.7 \\
\text { Percent } \\
23.4\end{array}$ & $\begin{array}{r}2,134.8 \\
\text { Percent } \\
30.0\end{array}$ & $\begin{array}{r}666.6 \\
\text { Percent } \\
9.4\end{array}$ & $\begin{array}{r}722.9 \\
\text { Percent } \\
10.2\end{array}$ & $\begin{array}{r}991.2 \\
\text { Percent } \\
14.0\end{array}$ & $\begin{array}{r}893.8 \\
\text { Percent } \\
12.7\end{array}$ & $7,064.0$ & 100.0 \\
\hline
\end{tabular}

Working Turpentine Area

Areas in which the trees are being chipped are designated as "working." If the trees are cupped for their first set of faces, the area is known as front-faced, while if a significant number of trees is being worked a second time, the area is known as back-faced. Almost 4 million acres, classified as working, form the turpentine area that is furnishing the present naval stores production and that also will furnish the bulk of the supply for the next decade. Nearly $3 \frac{1}{2}$ million acres of the working turpentine area has been back-faced, while half of the 7,064 crops worked in the 1934-35 season (table 8) were on back faces, indicating the intensity of naval-stores operations in south Georgia (fig. 19).

At the beginning of the 1934-35 season, there

TABLE 9.-Round turpentine pines 9 inches or larger in diameter and turpentined pines in different conditions on the various areas, 19.34

\begin{tabular}{|c|c|c|c|c|c|c|}
\hline \multirow[t]{2}{*}{ Areas } & \multirow{2}{*}{$\begin{array}{c}\begin{array}{c}\text { Round } \\
\text { trees }\end{array} \\
1,000 \\
\text { trees }\end{array}$} & \multirow{2}{*}{$\begin{array}{c}\begin{array}{c}\text { Work- } \\
\text { ing } \\
\text { trees }\end{array} \\
\begin{array}{c}1,000 \\
\text { trees }\end{array}\end{array}$} & \multirow{2}{*}{$\begin{array}{c}\begin{array}{c}\text { Rest- } \\
\text { ing } \\
\text { trees }\end{array} \\
1,000 \\
\text { trees }\end{array}$} & \multirow{2}{*}{$\begin{array}{c}\begin{array}{c}\text { Work- } \\
\text { ed-out } \\
\text { trees }\end{array} \\
1,000 \\
\text { trees }\end{array}$} & \multicolumn{2}{|c|}{ All conditions } \\
\hline & & & & & 1,000 & Per: \\
\hline Round-timber. & 13,880 & & 666 & 255 & 14,801 & 10.4 \\
\hline Working: & & & & & & \\
\hline Front-faced & 754 & 8,853 & 619 & 264 & 10,490 & 7.4 \\
\hline Back-faced & 2,435 & 56,329 & 6,287 & 10,034 & 75,085 & 52.9 \\
\hline $\begin{array}{l}\text { Resting and worked- } \\
\text { out }\end{array}$ & 7,670 & & 20,824 & 13,062 & 41,556 & 29.3 \\
\hline & 24,739 & 65,182 & 28,396 & 23,615 & 141,932 & \\
\hline Total. & Percent & $\begin{array}{r}\text { Percent } \\
45.9\end{array}$ & $\begin{array}{r}\text { Percent } \\
20.0\end{array}$ & $\begin{array}{r}\text { Percent } \\
16.7\end{array}$ & & 100.0 \\
\hline
\end{tabular}

were on the working areas (table 9), in addition to the 65 million working trees, almost 7 million resting trees having future faces, more than 3 million round trees at least 9.0 inches $d$. b. h., nearly 25 million round trees in the 8-inch diameter class, and more than 10 million worked-out trees.

Almost 13/4 million acres, or 42 percent, of the working area had approximately 21 possible back faces per acre at the time of the survey, in addition to the associated round trees. Less than one-half million acres, or 11 percent of the working area, is in the advanced sapling stage, with an average of 12 round trees per acre in the 8-inch and larger diameter classes and nearly 100 smaller trees that will be ready for working within a few years. More than one-half million acres, or 15 percent, will require 15 to 20 years to reach the well-developed stage. The remaining 11/4 million acres, or 32 percent, consists of intermingled reproduction, clear-cut and seed tree, and nonturpentine areas, which will have few or no naval stores possibilities for at least 20 years.

Although a 9-inch minimum diameter limit has been advocated for several years because hanging cups on smaller trees is generally unprofitable and considered poor woods practice, in 1934 about 30 percent of all the working trees in south Georgia were less than 9 inches d. b. h. In spite of the large number of small working trees, however, the average yield per crop in Georgia is greater than that in any other State in the principal naval stores belt. On the area in which new crops were established for the 1934-35 season, 36 percent of the round trees in 
the 8-inch diameter class were cupped. There are strong indications, however, that under the influence of the Naval Stores Conservation Program the practice of cupping trees below 9 inches is gradually being discontinued and that in recent years the percentage of small trees cupped may have been halved.

Comparison of the number of cups hung on virgin faces for the eight seasons of 1929-30 to 1936-37 is shown in figure 20. The data, except for the 193435 season, are approximate only and are based upon information from various sources. Despite the fact

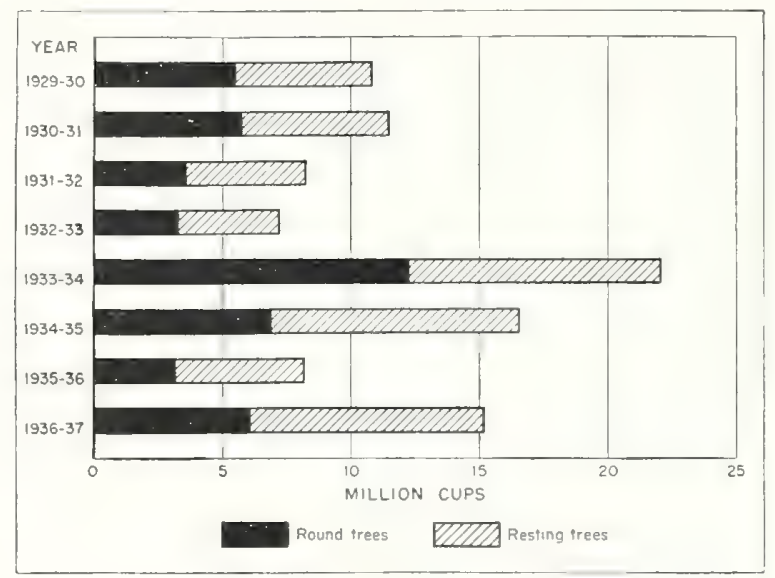

Figure 20.- Number of cups hung on virgin faces, 1929-30 to 1936-37.

that overproduction was one of the important factors responsible for the serious condition of the naval stores industry during the seasons of 1931-32 and 1932-33, approximately three times as many virgin cups were hung in 1933-34 as in either of the two preceding seasons.

\section{Resting and Worked-out Areas}

Areas which have been worked for at least one set of faces but which will furnish a sufficient number of back faces for further operation, and areas on which the trees of working size have been completely worked out, were grouped together in the field classification. They occupy approximately $2 \frac{1}{2}$ million acres, or 32 percent of the turpentine area. Approximately half of this area has an average of 18 future back faces per acre in addition to 6 round trees in the 10-inch diameter class, 11 in the 8 -inch class, and nearly 70 smaller. An addi- tional quarter of a million acres, which averages 12 round trees in the 8 -inch and larger diameter classes and almost 100 smaller round trees per acre, will be ready for working in a few years. The remaining acreage consists of young sapling, reproduction, clear-cut and seed tree, and intermingled nonturpentine pine areas, which cannot be expected to yield timber of turpentine size during the next 15 years or more.

In 1934 there was a total stand of 13 million worked-out trees on the resting and worked-out area (table 9), which together with 10 million worked-out trees on the back-faced working area should be removed from the stand to reduce competition for the remaining round, working, and resting trees, as well as to make way for a new crop of young growing stock. New markets for pulpwood throughout most of this region now furnish a much needed outlet for these trees, which had an aggregate volume of nearly 6 million cords.

\section{Future Timber Supply for Gum Naval Stores}

In south Georgia the turpentine timber supply has been more intensively used than in any other part of the naval stores belt, and many operators are now finding it increasingly difficult to obtain well-located and contiguous stands of round timber from which to meet their annual requirements for new crops. Although at first glance the survey results show enough round timber and partly worked trees on hand and in sight to maintain the industry at its present level or eventually to increase its production, when the many factors and circumstances that affect or limit the use of this supply are considered, the situation is not so favorable.

It is estimated that the annual production of gum naval stores in south Georgia for the 8 seasons from 1929-30 to 1936-37, inclusive, averaged approximately 282,000 units. Assuming an average annual gum yield of 43 units per crop, the total working body in operation each year would average at least 65 million faces. It would require the hanging of cups on approximately 6 million round trees each year to offset the crops abandoned and the constant shrinkage due to dry facing, tree mortality, and other losses. 


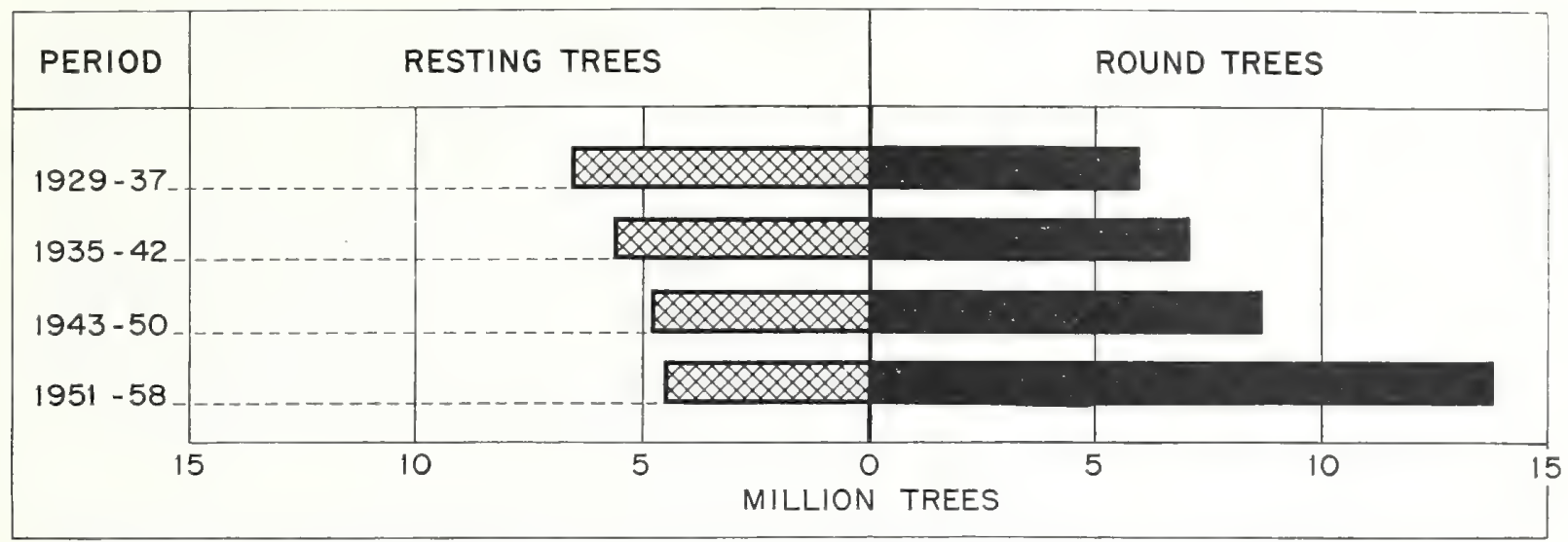

FIGURE 21.-Average annual demand for cups on round and resting turpentine pine trees, 1929-37, and trees in well-developed areas that may be ready for working annually in three other 8-year periods, 1935-42, 1943-50, and 1951-58.

The Forest Survey found that on well-developed areas the number of small round trees that progress annually into the turpentine sizes currently used (7.0-inch minimum) is sufficient to allow the hanging of 7 million cups each year on trees 7.0 inches d. b. h. and larger. These should support a total working body of over 70 million faces, which would be more than sufficient to maintain the present average annual production of gum naval stores. The theoretical annual income of round trees, together with the probable supply of resting trees upon which back faces may be hung, is shown for each of three 8-year periods in figure 21. It is estimated roughly that since 1929, on the average, approximately $6 \frac{1}{2}$ million cups have been hung on back faces annually. The combined front-face and back-face requirements thus may be compared with the theoretical possibilities. The estimates of future possibilities assume that, as in the past, the undesirable practice of placing cups on one-third of the trees in the 8-inch diameter class will be followed.

From this chart the conclusion might be drawn that the industry has a supply in sight with which to maintain its production at normal level during the first two 8-year periods, and that the production can be increased in the third period. The possibilities shown on the chart, however, must be discounted. In the first place, the trend in cupping practice, particularly since the advent of the Naval Stores Conservation Program, is toward a closer adherence to a 9-inch diameter limit. If this limit is adhered to, the annual income of trees of this size will not be large enough during the first 8 -year period to permit the hanging of the normal number of cups on round timber. Only 4.7 million round trees will reach 9.0 inches d. b.h. annually, and at 1 cup per tree this number would maintain a working body with a production of only 220,000 units, or 62,000 units less than the average production.

It must be kept in mind that the above computations are based upon the assumption that all round and working trees surviving will be available for naval stores operations. The demand for pulpwood, poles, piles, lumber, and cross ties, however, will probably bring about the cutting of more round trees and partly worked trees with future faces than in past years. This would reduce the supply for the gum naval stores industry.

Another point to be kept in mind in attempting to visualize the supply outlook is that the growing stock of turpentine timber, both round and partly worked, is not available to all operators. Some operators own a surplus or reserve supply greater than their needs, and consequently other operators will find it difficult to obtain timber as required. Actually, some of the timber may be withheld permanently from operation for naval stores.

Although all the growing stock used as a basis for the computation shown for the first period in figure 21 is located in well-developed turpentine stands, which will average 24 potential cups per acre, not all this timber is so well located or so well blocked that it can be turpentined conveniently. This situation, however, is not so serious as it might seem, owing to improved transportation and marketing facilities. Both regular operators and gum producers without stills are working smaller and more scattered stands of timber than previously. The ready cash market for raw gum created by the gum- 
cleaning processes, and the new and improved central stills make it possible for the small landowner to work his few scattered trees as part-time employment (fig. 22). Thus these changes in the industry are opening up an additional source of supply that heretofore was given small consideration. On the other hand, it is possible that because of the increasing production of, and rapid expansion of markets for, wood naval stores, and also because sulfate turpentine and "liquid rosin" (tall oil) are being developed as byproducts of the

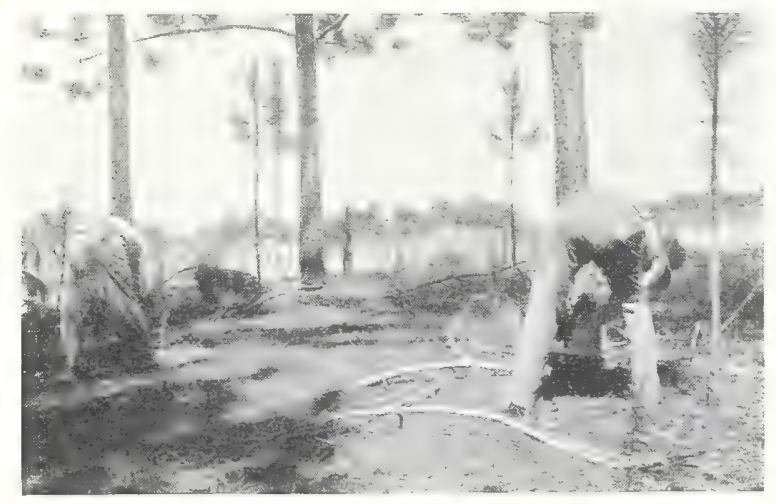

Figure 22.-A farmer and son chipping virgin faces on secondgrowth slash pine in his woodlot as part-time farm labor. Modern transportation facilities and a growing cash market for raw gum are making possible the utilization of hitherto unmerchantable stands and creating an additional, much needed source of farm income.

pulp industry, the demand for gum naval stores timber may be reduced.

Taking all of these circumstances into account, it would appear that for the first two 8-year periods (1935 to 1950), the gum naval stores industry in south Georgia will find it difficult to maintain its annual average production of 282,000 units without drawing heavily on the reserve necessary for future sustained yield. Continued improvement in turpentining practices, with a subsequent increase in average yield of gum per crop, and better protection from fire, may improve this situation.

With the growing competition of the wood-using industries for timber, the naval stores industry inevitably must own or control a much larger proportion of forest land than it has in the past, if it wishes to protect and assure its supply. The survey found that in the 1934-35 season less than 30 percent of the crops in operation by turpentine processors were owned by them, while the remaining 70 percent were leased. Under such conditions, the industry is in a vulnerable position. Operators who own their timberland not only can control the use of the timber but also can practice good forestry measures that will increase materially the number of trees per acre and the value of the timber stand; they can thus assure themselves of a continuous supply for their turpentine operations. Furthermore, by combining a woods-products business with their naval stores production they should be able to reduce materially the overhead and carrying costs charged against rosin and turpentine. Among the good forestry measures recommended are fire protection, conservative cupping and chipping, thinning dense stands, improvement cuttings, and integrated utilization designed to produce lumber, poles, piles, ties, and pulpwood, in addition to naval stores.

\section{Wood Naval Stores Industry and Resources}

The wood naval-stores industry of Georgia, which gives full-time employment to approximately 1,000 people, began about 1920, when a large company purchased and enlarged a steam-solvent distillation plant at Brunswick. Using principally well-seasoned old-growth longleaf pine stumps as raw material, this company, with efficient research and an active sales department, has in the past few years developed its original products, consisting of one grade of rosin (FF), wood turpentine, and pine oil, into a large series of chemical products. Steam-solvent plants in the South yield as basic products an average of $61 / 2$ gallons of turpentine, $6 \frac{1}{4}$ gallons of pine oil, and 350 pounds of rosin per ton of stump wood.

Two destructive-distillation plants, operating on both stump and top wood, produce an average of 35 gallons of crude pine tars and oils and 345 pounds of charcoal per ton. The three plants used approximately 230,000 tons of wood in 1936. All together, wood naval stores in 1934 accounted for approximately 17 percent of the total rosin produced in south Georgia and 8 percent of the turpentine.

The steam-solvent wood-distillation industry has been experimenting for some time with the raw gum from living trees, and several plants throughout the naval stores region are at present purchasing and processing raw gum. This phase of the industry will undoubtedly be improved and expanded. 


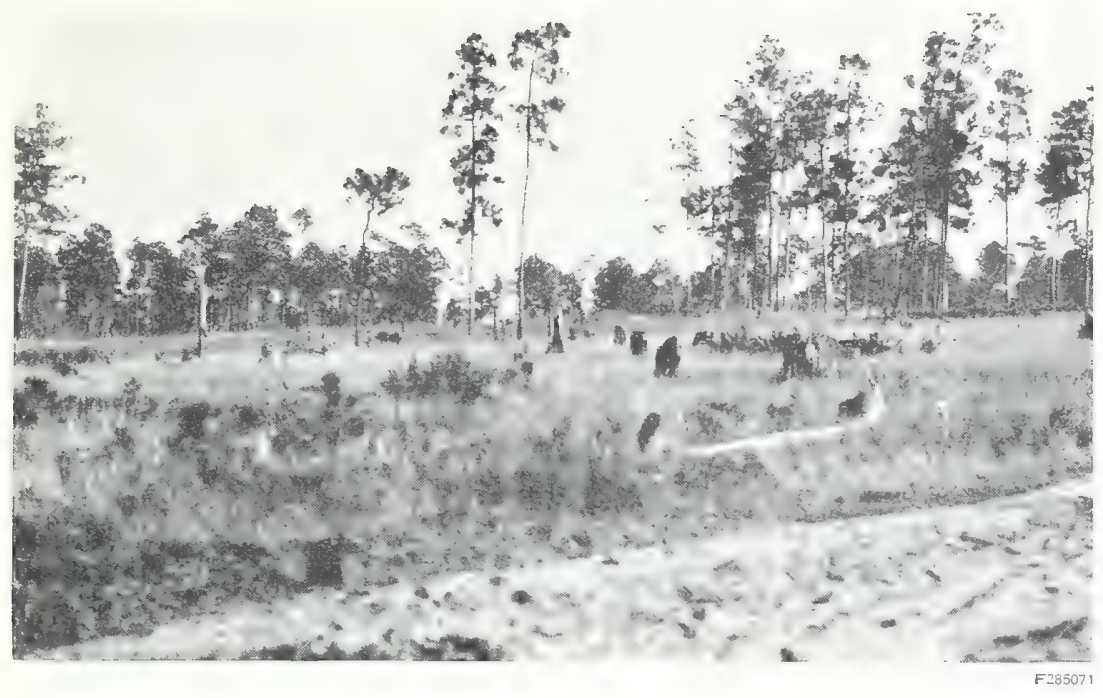

FIGURE 23.-Merchantable stump land in the flatwoods of south Georgia, a source of supply for wood naval stores.

Suitable supplies of merchantable stumps are found mainly in the longleaf pine, longleaf-slash pine, and scrub oak types, the latter occupying areas formerly in old-growth longleaf pine. Although land that has been clear-cut and has not yet reforested is considered the best source of stumps, many stumps are obtained also from land supporting reproduction and small saplings (fig. 23). Many owners hesitate to allow the removal of stumps on land that bears well-established young growths, as the damage to the stands often is greater than the return from the sale of the stumps.

Stumps are extracted commercially either with the use of powder or with large machines that pull and remove the stumps and their taproots. In locations suitable for stump-pulling machines, they have a decided advantage in cost of removal per ton and in tonnage removed per acre. Areas "stumped" with machines generally yield about two-thirds more volume than those stumped with powder (fig. 24).

As it is impracticable to operate the heavy stumpextracting machinery in wet, swampy locations, stumps in swamps, bays, ponds, and river bottoms, even though suitable for distillation, are seldom removed. Although in south Georgia approximately 31 percent of the forest area is so classified (table 2), these unfavorable locations contain less than 3 percent of the merchantable stump wood volume. Any future possibility of extracting stumps from these difficult situations would, therefore, increase the potential supply very little.
Topography, soil, density of stumps, and other influencing factors combine, however, to restrict the area suitable for stump-pulling machines to a relatively unimportant totaI. Consequently, the figures used hereafter in this report refer only to the tonnage that can be removed through blasting. The area of merchantable stump land is given in table 10 , classified according to topographic situation and number of merchantable stumps per acre. Only areas lightly enough stocked with living trees to permit stump extraction without serious damage to the standing timber are included in this table. There are 618,600 acres which have too few stumps (five or less per acre) to warrant extraction operations under present practices.

Approximately 38 percent of the stump land, or a little less than 1 million acres, lies in the flatwoods

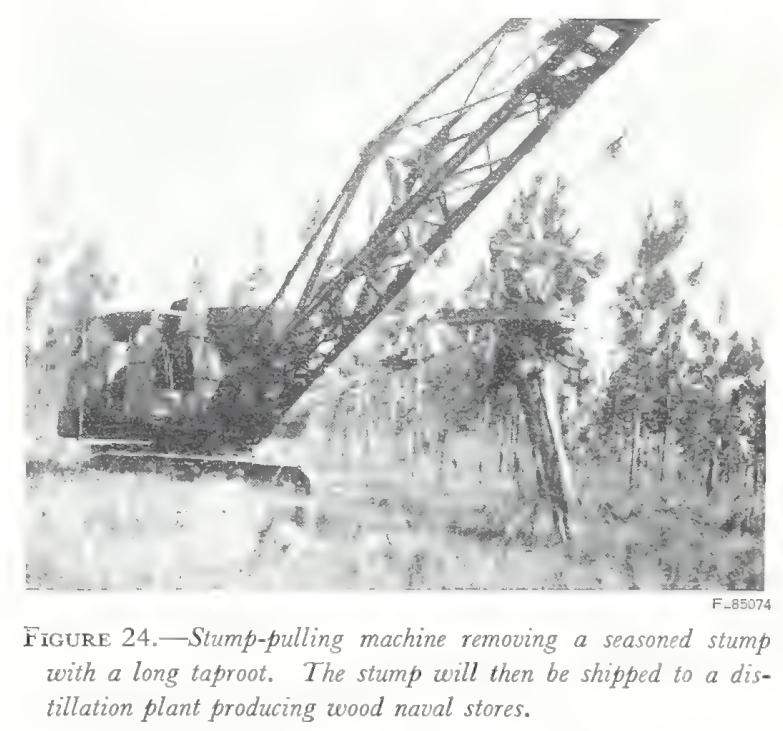

and has sufficient volume (averaging $41 / 2$ tons per acre) to be considered as productive stump land.

When the volume of merchantable stumps, as in table 10, is classified according to stumps per acre, about 97 percent is found to be located in areas of sufficient density to warrant extraction.

A total of approximately $73 / 4$ million tons of merchantable stumps was found on less than $2 \frac{1}{2}$ 
million acres of stump land. Almost 69 percent of the present merchantable area of stump land is in open second-growth stands, approximately 21 percent is in the clear-cut areas generally accepted as the most available, and 10 percent is in old-growth stands.

In addition to the present supply of merchantable stumps in areas that favor removal, there are, in many of the advanced second-growth stands, wellseasoned stumps that cannot be removed without damage to surrounding trees or without undue cost. Recently cut old-growth stumps, which must season 8 to 10 years after cutting before they become suitable for use, form another source of supply at present unavailable. Almost 8 million tons of stumps are in the above two groups. A considerable amount of stump wood will also be available from the stumps of old-growth longleaf timber now standing. At a conservative estimate of 3 tons per acre, this would add over 1 million tons, making a total of 9 million tons of stump wood as a future available supply.

With an actual and potential supply of about $16^{3 / 4}$ million tons of merchantable stumps, it is evident that south Georgia has, theoretically at least, sufficient tonnage to meet the 230,000 tons of annual requirements of the plants in the area for many years. In practice it is likely that a considerable part of this indicated supply will never reach a manufacturing plant, because of such factors as high cost of transportation, attrition of fire and rot, demands for fuel, and the action of landowners in protecting young growth that stump removal would destroy. Nevertheless, there appear to be
TABLE 10.-Merchantable stump-land area, and volume of merchantable stumps (blasting basis), classified according to abundance of stumps and topographic situation, 1934

\begin{tabular}{|c|c|c|c|c|c|}
\hline $\begin{array}{l}\text { Stumps per acre } \\
\text { (number) }\end{array}$ & $\begin{array}{l}\text { Flat- } \\
\text { woods }\end{array}$ & $\begin{array}{c}\text { Rolling } \\
\text { uplands }\end{array}$ & \begin{tabular}{|c|} 
River \\
bottoms, \\
swamps, \\
bays, \\
branch \\
heads. \\
etc. \\
\end{tabular} & \multicolumn{2}{|c|}{ All situations } \\
\hline & Acres & Acres & Acres & Acres & Per- \\
\hline 5 or less . . . . . . & 219,900 & 376,500 & 22,200 & 618,600 & 25.9 \\
\hline 6 to $13 \ldots \ldots$ & 301,700 & 378,100 & 16,000 & 695,800 & 29.1 \\
\hline 14 to 25 & 312,500 & 251,500 & 19,500 & 583,500 & 24.4 \\
\hline 26 or more & 300,100 & 182,500 & 11,400 & 494,000 & 20.6 \\
\hline $\begin{array}{l}\text { Total stump-land } \\
\text { area }\end{array}$ & $\left\{\begin{array}{r}1,134,200 \\
\text { Percent } \\
\mathbf{4 7 . 4}\end{array}\right.$ & $\begin{array}{r}1,188,600 \\
\text { Percent } \\
49.7\end{array}$ & $\begin{array}{r}69,100 \\
\text { Percent } \\
2.9\end{array}$ & $2,391,900$ & 100.0 \\
\hline \multicolumn{6}{|c|}{ STUMP VOLUME } \\
\hline & 1,000 tons & 1,000 tons & 1,000 tons & 1,000 tons & $\begin{array}{l}\text { Per- } \\
\text { cent }\end{array}$ \\
\hline 5 or less ........ & 88 & 149 & 10 & 247 & 3. 2 \\
\hline 6 to 13 & 604 & 756 & 32 & 1,392 & 18. 1 \\
\hline 14 to $25 \ldots$ & 1,250 & 1,007 & 78 & 2,335 & 30.4 \\
\hline 26 or more & 2,250 & 1,369 & 86 & 3,705 & 48.3 \\
\hline $\begin{array}{l}\text { Total volume on } \\
\text { stump-land area }\end{array}$ & $\begin{array}{r}4,192 \\
\text { Percent } \\
54.6\end{array}$ & $\begin{array}{r}3,281 \\
\text { Percent } \\
42.7\end{array}$ & $\mid \begin{array}{r}206 \\
\text { Percent } \\
2.7\end{array}$ & 7,679 & 100.0 \\
\hline
\end{tabular}

enough stumps to permit a considerable expansion in the production of wood naval stores, should the demand and prices for such products warrant it. The utilization of stumps for naval stores must be considered as a mining rather than a farming (i. e., renewable crop) operation, since the supply will be exhausted when the large stumps mentioned are used up. There is little likelihood that an appreciable amount of the present second-growth stands will ever reach sufficient age to produce stumps suitable for naval stores. 


\section{Wood Products}

iो

\section{Volume Estimates}

$\mathrm{T}$

$1 \mathrm{HE}$ volumes of sound wood are estimated in three units of measure: Board feet, cords, and cubic feet. The board-foot estimate includes all the material that has the size and quality of saw timber. The cordwood estimate includes the board-foot volume converted to cords, including bark, and in addition the material in trees under sawlog size, in the tops of saw-timber trees, and the sound material in cull trees, all of which additional material is unsuited for saw timber but which is convertible into such commodities as pulpwood, fuel wood, fence posts, etc. The cubic-foot estimate expresses the volume inside bark of all material included in the cordwood estimate.

\section{Saw-Timber Volumes}

In estimating saw-timber volumes, only merchantable timber in live trees of commercial species was included. All figures are net, deduction having been made for loss due to turpentining and for both woods and mill cull, i. e., portions of the tree which are not suitable for lumber on account of rot, crook, firescars, bad knots, sweep, or other defects.

Board-foot volumes by species groups are expressed in Doyle, Scribner, and International $1 / 4$-inch rules in table 11 . The Doyle rule is given because it is commonly used throughout Georgia and the South, even though it underestimates the lumber which may be cut from small logs and overestimates the contents of large logs; only in logs 25 to 35 inches in diameter does it closely approximate lumber tally. The Scribner rule, which is one of the official log rules of the Forest Service, is more uniform than the Doyle rule, but still underestimates lumber tally, particularly in the smaller logs. The International $1 / 4$-inch rule closely approximates green-lumber mill tally, and is used throughout this report to express green-lumber tally in the more detailed tables of volume and also in the calculations of saw-timber growth and drain. As shown in table 11, the total net saw-timber volume, lumber tally, for south Georgia, as inventoried in 1934, was about 18.5 billion board feet.

As inventoried in 1934 and shown in table 12, more than two-thirds of this total volume of saw timber is in pines, over a quarter is in hardwoods, and a small remainder in cypress. Approximately 40 percent of the volume of pines, hardwoods, and cypress combined is in old-growth

TABLE 11.-Net board-foot volume expressed in Doyle and Scribner log rules and in lumber tally, $1934^{1}$

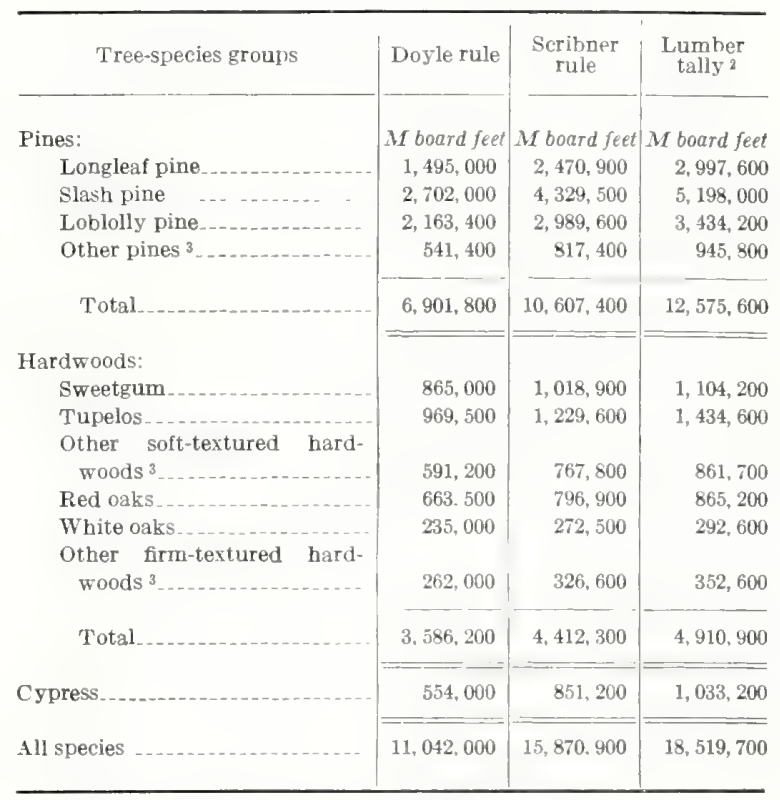

1 Special-use species and scrub oaks not included.

2 Based on International 1/4-inch rule.

${ }^{3}$ See p. 4 for list of species included. 
TABLE 12.-Net board-foot volume, lumber tally, by major species groups and forest conditions, 1934

\begin{tabular}{|c|c|c|c|c|c|c|c|c|}
\hline \multirow{3}{*}{ Species group } & \multicolumn{2}{|c|}{ Old growth } & \multicolumn{3}{|c|}{ Second growth } & \multirow{3}{*}{$\begin{array}{l}\text { Reproduc- } \\
\text { tion and } \\
\text { clear-cut }\end{array}$} & \multirow{2}{*}{\multicolumn{2}{|c|}{ All forest conditions }} \\
\hline & \multirow{2}{*}{ Uncut } & \multirow{2}{*}{ Partly cut } & \multicolumn{2}{|c|}{ Sawlog size } & \multirow{2}{*}{$\begin{array}{l}\text { Under saw- } \\
\text { log size }\end{array}$} & & & \\
\hline & & & Uncut & Partly cut & & & & \\
\hline $\begin{array}{l}\text { Pines: } \\
\text { Turpentine: } \\
\quad \begin{array}{l}\text { Round ... } \\
\text { Worked }\end{array} \\
\begin{array}{l}\text { Nonturpentine } \\
\text { Non }\end{array}\end{array}$ & $\begin{array}{l}\text { M board } \\
\text { feet } \\
259,600 \\
360,700 \\
745,200\end{array}$ & $\begin{array}{l}M \text { board } \\
\text { feet } \\
352,000 \\
1,475,000 \\
514,000\end{array}$ & $\begin{array}{l}M \text { board } \\
\quad \text { feet } \\
1,229,500 \\
3,079,300 \\
2,445,400\end{array}$ & $\begin{array}{l}M \text { board } \\
\text { feet } \\
114,700 \\
347,200 \\
438,300\end{array}$ & $\begin{array}{l}\text { M board } \\
\text { feet } \\
227,500 \\
608,100 \\
217,500\end{array}$ & $\begin{array}{l}M \text { board } \\
\text { feet } \\
25,100 \\
116,900 \\
19,600\end{array}$ & $\begin{array}{l}M \text { board } \\
\quad \text { feet } \\
2,208,400 \\
5,987,200 \\
4,380,000\end{array}$ & $\begin{array}{l}\text { Percent } \\
11.9 \\
32.3 \\
23.7\end{array}$ \\
\hline Total $\ldots \quad \ldots \ldots \ldots$ & $1,365,500$ & $2,341,000$ & $6,754,200$ & 900,200 & $1,053,100$ & 161,600 & $12,575,600$ & 67.9 \\
\hline $\begin{array}{l}\text { Hardwoods: } \\
\quad \text { Snft-textured ... } \\
\quad \text { Firm-textured }\end{array}$ & $\begin{array}{r}1,308,700 \\
699,100\end{array}$ & $\begin{array}{l}841,700 \\
326,600\end{array}$ & $\begin{array}{l}998,000 \\
369,000\end{array}$ & $\begin{array}{r}180,300 \\
75,000\end{array}$ & $\begin{array}{l}68,800 \\
38,900\end{array}$ & $\begin{array}{l}3,000 \\
1,800\end{array}$ & $\begin{array}{l}3,400,500 \\
1,510,400\end{array}$ & $\begin{array}{r}18.3 \\
8.2\end{array}$ \\
\hline Total ... ........... & $2,007,800$ & $1,168,300$ & $1,367,000$ & 255,300 & 107,700 & 4,800 & $4,910,900$ & 26.5 \\
\hline -1, & 223,200 & 404,300 & 277,100 & 52,500 & 67,500 & 8,600 & $1,033,200$ & 5. 6 \\
\hline All species ....... & $\begin{array}{l}3,596,500 \\
\text { Percent } \\
19.4\end{array}$ & $\begin{array}{r}3,913,600 \\
\text { Percent } \\
21.1\end{array}$ & $\begin{array}{l}8,398,300 \\
\text { Percent } \\
45.4\end{array}$ & $\begin{array}{r}1,208,000 \\
\text { Percent } \\
6.5\end{array}$ & $\begin{array}{r}1,228,300 \\
\text { Percent } \\
6.6\end{array}$ & $\begin{array}{l}\text { 175, } 000 \\
\text { Percent } \\
\text { 1. } 0\end{array}$ & $\begin{array}{c}18,519,700 \\
\text { Percent }\end{array}$ & 100.0 \\
\hline
\end{tabular}

TABLE 13.-Diameter-class distribution of net board-foot volume, lumber tally, by species groups and forest conditions, 1934

\begin{tabular}{|c|c|c|c|c|c|c|c|c|}
\hline \multirow{3}{*}{ Species groun and diameter class (inches) } & \multicolumn{2}{|c|}{ Old growth } & \multicolumn{3}{|c|}{ Second growth } & \multirow{3}{*}{$\begin{array}{l}\text { Reproduc- } \\
\text { tion and } \\
\text { clear-cut }\end{array}$} & \multirow{3}{*}{\multicolumn{2}{|c|}{ All forest conditions }} \\
\hline & \multirow{2}{*}{ Uncut } & \multirow{2}{*}{ Partly cut } & \multicolumn{2}{|c|}{ Sawlog size } & \multirow{2}{*}{$\begin{array}{l}\text { Under saw- } \\
\text { log size }\end{array}$} & & & \\
\hline & & & Uncut & Partly cut & & & & \\
\hline $\begin{array}{l}\text { Pine: } \\
\qquad \begin{array}{l}10 \text { to } 12 \\
14 \text { to } 16 \\
18 \text { to } 20 \\
22 \text { and over } 1\end{array}\end{array}$ & $\begin{array}{l}M \text { board } \\
\text { feet } \\
220,000 \\
394,600 \\
315,200 \\
435,700\end{array}$ & $\begin{array}{c}M \text { board } \\
\text { feet } \\
670,200 \\
883,100 \\
444,600 \\
343,100\end{array}$ & $\begin{array}{c}M \text { board } \\
\text { feet } \\
2,808,800 \\
2,558,500 \\
975,600 \\
411,300\end{array}$ & $\begin{array}{c}M \text { board } \\
\text { feet } \\
377,900 \\
367,100 \\
120,700 \\
34,500\end{array}$ & $\begin{array}{l}\text { M board } \\
\quad \text { feet } \\
680,700 \\
306,900 \\
46,600 \\
18,900\end{array}$ & $\begin{array}{c}M \text { board } \\
\text { feet } \\
81,200 \\
62,500 \\
14,200 \\
3,700\end{array}$ & $\begin{array}{c}M \text { bonrd } \\
\text { feet } \\
4,838,800 \\
4,572,700 \\
1,916,900 \\
1,247,200\end{array}$ & $\begin{array}{r}\text { Percent } \\
38.5 \\
36.4 \\
15.2 \\
9.9\end{array}$ \\
\hline Total .... & $1,365,500$ & $2,341,000$ & $6,754,200$ & 900,200 & $1,053,100$ & 161,600 & $12,575,600$ & 100. 0 \\
\hline $\begin{array}{l}\text { Hardwood: } \\
14 \text { to } 18 \\
20 \text { to } 28 \\
30 \text { and over }\end{array}$ & $\begin{array}{l}818,100 \\
882,900 \\
306,800\end{array}$ & $\begin{array}{l}622,200 \\
436,300 \\
109,800\end{array}$ & $\begin{array}{r}933,000 \\
387,900 \\
46,100\end{array}$ & $\begin{array}{r}177,100 \\
74,300 \\
3,900\end{array}$ & $\begin{array}{r}77,700 \\
21,300 \\
8,700\end{array}$ & $\begin{array}{r}3,900 \\
900\end{array}$ & $\begin{array}{r}2,632,000 \\
1,803,600 \\
475,300\end{array}$ & $\begin{array}{r}53.6 \\
36.7 \\
9.7\end{array}$ \\
\hline Total $\ldots . .$. & $2,00 \overline{7}, 800$ & $1,168,300$ & $1,367,000$ & 255,300 & 107,700 & 4,800 & $4,910,900$ & 100.0 \\
\hline $\begin{array}{l}\text { Cypress: } \\
10 \text { to } 12 \\
14 \text { to } 16 \\
18 \text { to } 20 \\
22 \text { and over } 2\end{array}$ & $\begin{array}{l}64,000 \\
51,300 \\
30,700 \\
77,200\end{array}$ & $\begin{array}{r}182,900 \\
93,000 \\
41,000 \\
87,400\end{array}$ & $\begin{array}{r}156,200 \\
80,000 \\
18,400 \\
22,500\end{array}$ & $\begin{array}{r}35,700 \\
13,100 \\
2,700 \\
1,000\end{array}$ & $\begin{array}{r}51,700 \\
10,900 \\
2,300 \\
2,600\end{array}$ & $\begin{array}{r}4,700 \\
2,100 \\
600 \\
1,200\end{array}$ & $\begin{array}{r}495,200 \\
250,400 \\
95,700 \\
191,900\end{array}$ & $\begin{array}{r}47.9 \\
24.2 \\
9.3 \\
18.6\end{array}$ \\
\hline Total ..... & 223,200 & 404,300 & $2 \pi 7,100$ & 52,500 & 67,500 & 8,600 & $1,033,200$ & 100.0 \\
\hline All species....... & $3,596,500$ & $3,913,600$ & $8,398,300$ & $1,208,000$ & $1,228,300$ & 175,000 & $18,519,700$ & \\
\hline
\end{tabular}

${ }^{1}$ Includes $161,300 \mathrm{M}$ board feet in trees 29.0 inches d. b. h. and over.

${ }^{2}$ Includes $74,200 \mathrm{M}$ board feet in trees 29.0 inches d. b. h. and over. 


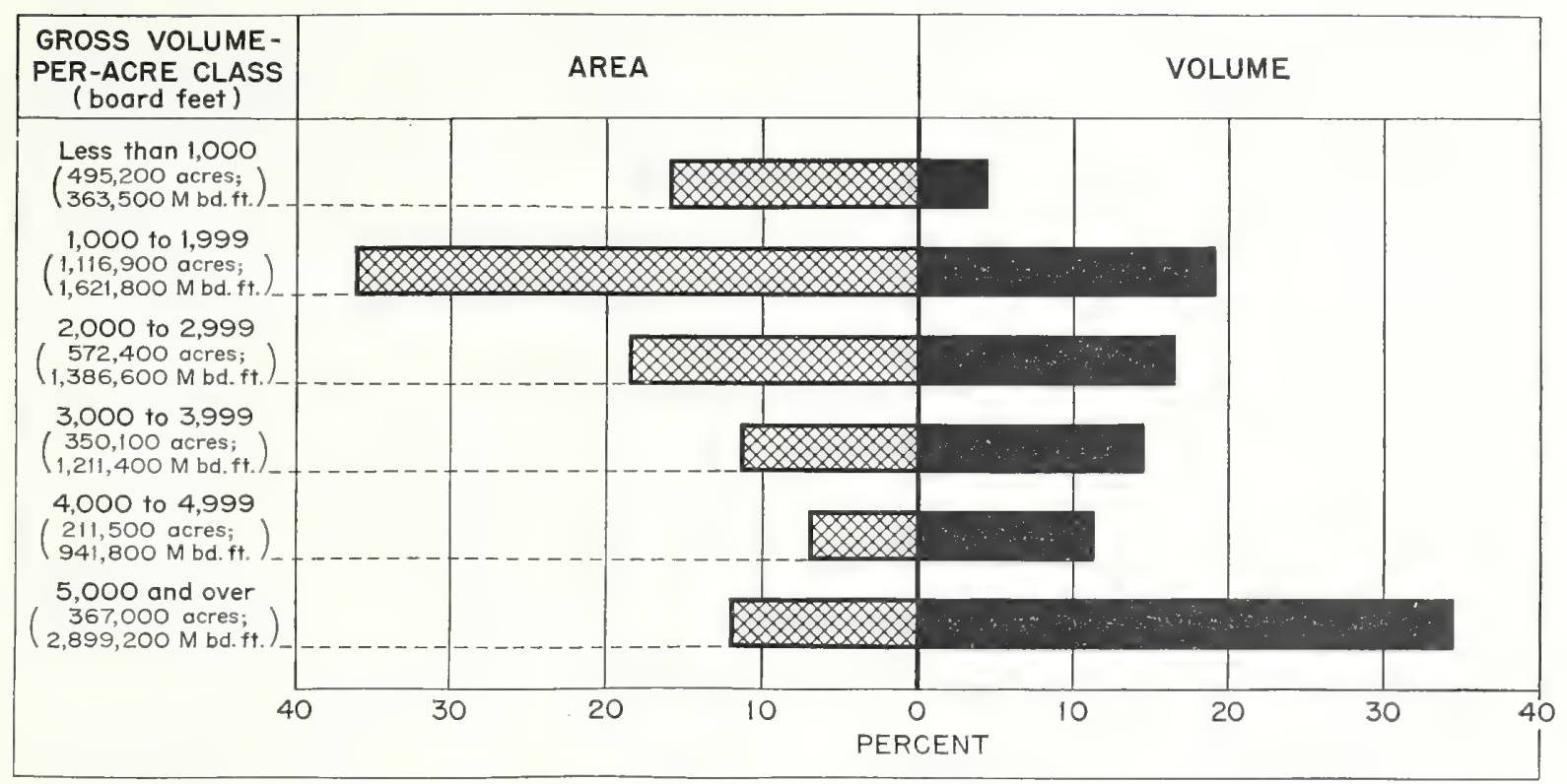

Frgure 25.-Proportional area and volume (iumber tally) of sawlog-size timber in the turpentine pine types, classified according to volume of saw timber per acre. Turpentined butts are not included.

stands, 59 percent is in second growth, and 1 percent is scattered throughout the clear-cut and reproduction areas.

Trees which have been worked for turpentine, or are at present being worked, account for 48 percent of the pine volume. More than 17 percent is in round longleaf and slash pines, 27 percent is in loblolly pine, and the remaining 8 percent is in other nonturpentine pines, principally pond, spruce, shortleaf, and sand pines. Approximately 3.7 billion board feet, or 29 percent of the pine saw-timber volume, occurs on old-growth areas, and 8.9 billion board feet, or 71 percent, in second-growth stands. Approximately 75 percent is in the 10 - to 16 -inch diameter-classes (table 13).

Tupelos and sweetgum and other soft-textured hardwood trees, classified as pulping hardwoods, constitute 70 percent of the hardwood volume. As shown in table 13 , approximately 46 percent of the hardwood volume is in trees at least 19.0 inches d.b.h., which produce relatively high-grade material, the remaining 54 percent representing logs of lower quality.

Practically all the saw-timber volume is physically accessible with modern, mobile, effective logging equipment and the present excellent transportation facilities.

Volume-per-acre distribution is indicated for the sawlog-size conditions of the turpentine pine types in figure 25. These data are based on gross boardfoot volume, but with turpentine butts excluded. While the figures of the smallest volume-per-acre class may not be truly indicative, they become significant when combined with those of the next larger class (1,000 to 1,999 board-feet per acre). In the type group and under the conditions here being considered, more than 76 percent of the volume occurs on 48 percent of the area in stands of 2,000 board-feet per acre or more. Although it is common practice in this area to log stands that will yield as little as 400 board feet per acre, this is generally done to remove worked-out naval stores timber or to carry on similar salvage operations.

\section{Cordwood Volumes}

A considerable volume of material in standing timber, because of its small size or poor quality, must go into such uses as pulpwood, fuel wood, fence posts, etc., if utilized now. This volume is found principally in the stems of sound trees under sawlog size, in the tops of sawlog-size trees, in the portion of the butts unusable for saw timber, and in the sound portions of cull trees. Together with the volume in sawlog material already shown in board feet, it is expressed in cords in table 14 .

Obviously not all this volume is immediately available, nor should it be used in the form of 
TABLE 14. - Net cordwood volume ¿ by species groups and quality classes, 1934

\begin{tabular}{|c|c|c|c|c|c|c|c|}
\hline \multirow{2}{*}{ Species group } & \multicolumn{2}{|c|}{ Sound sawlog-size trees } & \multirow{2}{*}{$\begin{array}{l}\text { Sound trees } \\
\text { under saw- } \\
\text { log size }{ }^{3}\end{array}$} & \multirow{2}{*}{$\begin{array}{l}\text { Total sound- } \\
\text { tree volume }\end{array}$} & \multirow{2}{*}{ Cull trees \& } & \multirow{2}{*}{\multicolumn{2}{|c|}{ All quality classes }} \\
\hline & Sawlog ma- & Tops and & & & & & \\
\hline Pines: & Cords & Cords & Cords & Cords & Cords & Cords & Percent \\
\hline Round & $5,295,300$ & $1,152,300$ & $9,671,500$ & $16,119,100$ & 60,900 & $16,180.000$ & 15. 1 \\
\hline Turpentined ...... & $13,957,100$ & $5,561,900$ & $5,307,600$ & $24,826,600$ & 122,400 & $24,949,000$ & 23.2 \\
\hline Nonturpentine ${ }^{5}$ & $9,851,700$ & $1,808,000$ & $2,171,300$ & $13,831,000$ & 219,300 & $14,050,300$ & 13. 1 \\
\hline Total & $29,104,100$ & $8,522,200$ & $17,150,400$ & $54,776,700$ & 402,600 & $55,179,300$ & 51.4 \\
\hline \multicolumn{8}{|l|}{ Hardwoods: } \\
\hline Soft-textured 5 & $8,562,100$ & $4 ; 491,000$ & $13,848,200$ & $26,901,300$ & $6,736,100$ & $33,637,400$ & 31.4 \\
\hline Firm-textured ${ }^{5}$ & $3,623,300$ & $2,094,000$ & $3,416,200$ & $9,133,500$ & $3,486,700$ & $12,620,200$ & 11.8 \\
\hline Total & $12,185,400$ & $6,585,000$ & $17,264,400$ & $36,034,800$ & $10,222,800$ & $46,257,600$ & 43.2 \\
\hline C spress.... & $2,623,300$ & 797,900 & $1,652,500$ & $5,073,700$ & 676,800 & $5,750,500$ & 5,4 \\
\hline \multirow[t]{2}{*}{ All species } & $\begin{array}{l}43,912,800 \\
\text { Percent }\end{array}$ & $\begin{array}{c}15,905,100 \\
\text { Percent }\end{array}$ & $\begin{array}{l}36,067,300 \\
\text { Percent }\end{array}$ & $\begin{array}{l}95,885,200 \\
\text { Percent }\end{array}$ & $\begin{array}{l}11,302,200 \\
\text { Percent }\end{array}$ & $107,187,400$ & \\
\hline & 41.0 & 14.8 & 33.6 & 89.4 & 10.6 & & $10 \% .0$ \\
\hline
\end{tabular}

1 A cord $=90$ cubic feet of pine or eypress wood and bark, or 80 cubic feet of hardwood.

2 Includes the upper stems in pines and stems plus large limbs in hardwoods and cypress; also sound cordwood material in butt sections of pines not considered usable for board-foot material.

${ }^{3}$ Volume of stem only to usable top diameter, never less than 4 inches. Includes all volume of special-use species in the firm-textured hardwood species group.

1 Sound material in cull trees 5 inches d. b. h. and larger, including limbs of large hardwood and cypress culls; all sound scrub oak is included under firm-textured hardwoods.

5 See p. 4 for list of species included.

TABLE 15.-Net cubic-foot volume (inside bark), by species groups and quality classes, 1934

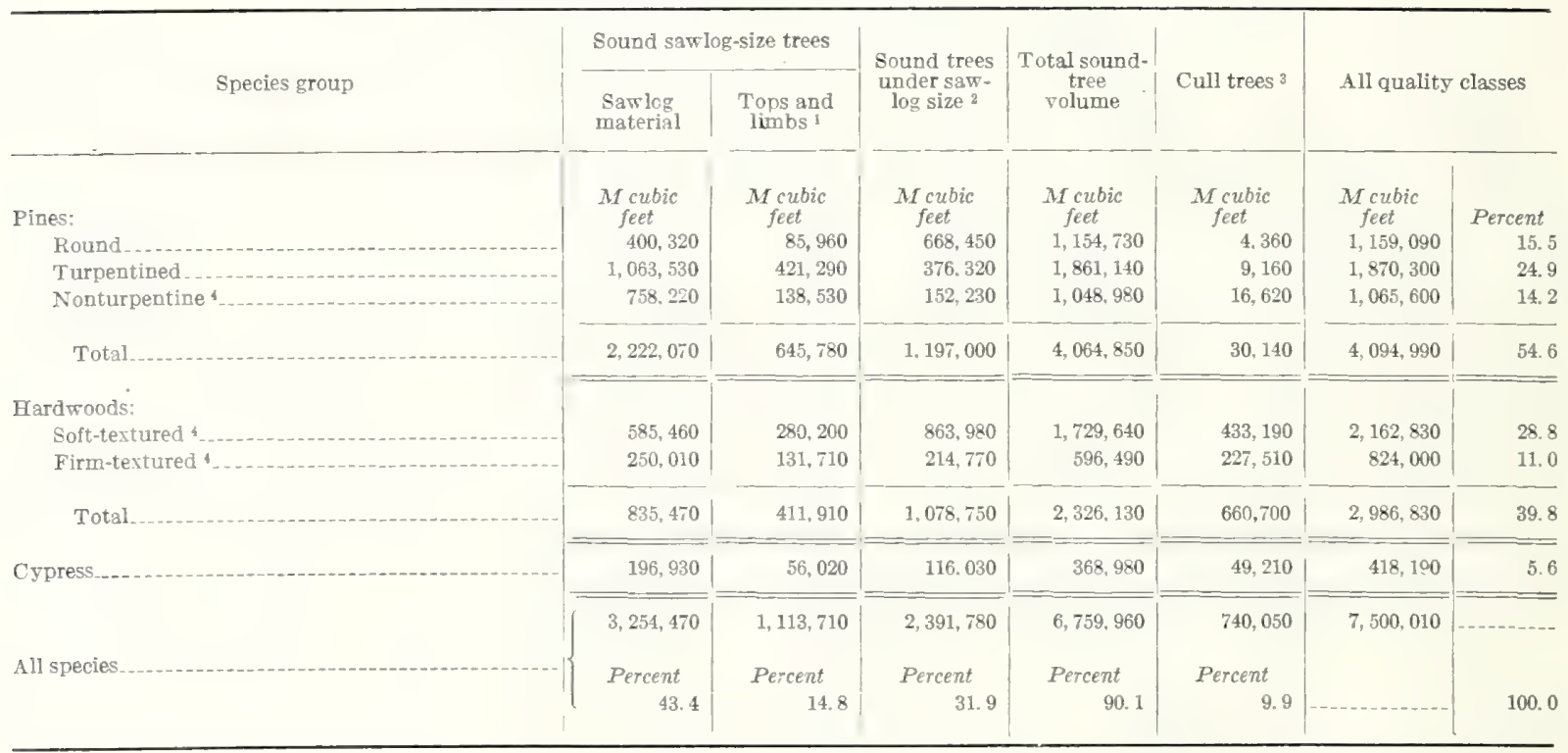

1 Includes the sound material in butt sections of sawlog-size turpentined pine trees that is not considered usable for board-foot material.

2 The firm-textured hardwood species group includes all volume in special-use species, of which 35,000 cubic feet (i. b.) was in tops and limbs of sawlogsize trees.

${ }^{3}$ Sound material in cull trees; all sound scrub oak is included under firm-textured hardwoods.

4 See p. 4 for list of species included. 
cordwood. The 44 million cords in sawlog-size material, which is usually far more valuable for lumber, and the 36 million cords in sound trees under sawlog size, which forms the nucleus of the future saw-timber growing stock, should be cut with restraint to safeguard future supplies. The 9 million cords in tops and limbs of sawlog-size pines will become available as the trees are cut, together with the 7 million cords of similar material in hardwoods and cypress not used extensively thus far. The remaining 11 million cords, or

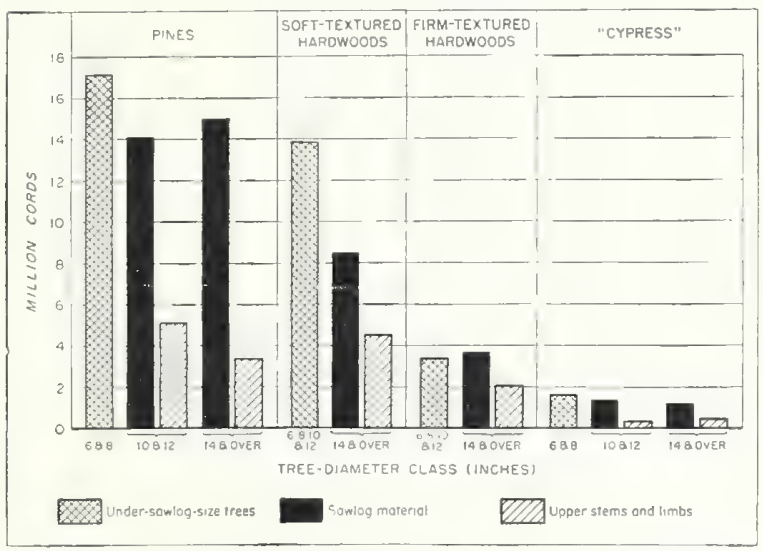

Figure 26.-Cordwood volume of sound trees by species groups, diameter classes, and sources of material.

more than 10 percent, in cull trees scattered throughout the region should be salvaged where possible.

Of the 107 million cords shown in table 14, divided chiefly between pines and hardwoods, approximately 31 percent, excluding cull trees and tops and limbs of sawlog-size hardwoods and cypress, is in the old-growth condition, and 68 percent is in second growth. The negligible remainder is in the clear-cut areas.

Figure 26 shows diagrammatically the cordwood volume of sound trees by species groups and diameter classes. Approximately two-thirds of the pine and cypress volume and half of the hardwood volume is in trees less than 13.0 inches $\mathrm{d} . \mathrm{b} . \mathrm{h}$.

\section{Cubrc-Foot Volumes}

The cubic-foot volume, which is measured inside bark, includes sound wood only. Although this form of measurement is not used in commercial practice at the present time, it is presented here as a means of expressing the total wood content of the forest stand in terms of a single unit. Of a total of approximately $7 \frac{1}{2}$ million cubic feet of sound material, 54 percent is pine (table 15). Of the cubic-foot volume 58 percent is in sawlog-size trees, about a third in under-sawlog-size trees, and 10 percent in culls. About 54 percent of the pine volume is in sawlog material, but only 28 percent of the hardwood volume. The cubic-foot growing stock used as a basis for computing increment excludes the upper stems and limbs of sawlog-size hardwoods, cypress, and cull trees.

\section{Poles and Piles}

A special inventory was made of trees suitable for poles (based upon the specifications of the American Standards Association) and piles. Because of the difficulty of judging standing trees for this purpose, there was a marked tendency on the part of timber cruisers to apply the specifications rather strictly, and consequently it is believed that the estimate of the number of qualified trees is conservative. Although cypress with sufficient heartwood content is also used for poles and piles, no effort was made to estimate the number of suitable trees because of the uncertainty of the amount of heartwood. In the following estimates, therefore, only longleaf, slash, and loblolly pines are included.

To meet pole and pile requirements, trees must have a uniform taper and be free from decay, bird and insect holes, and injurious scars. They must also be free from large knots or those so located as to impair the strength of the pole, and from short crooks, excessive twist, and spiral grain. They may have a one-way sweep, provided a straight line drawn from the center of the top to the center of the butt does not fall outside the body of the pole at any point.

Pole and pile trees are scattered singly and in groups throughout the pine stands of the area. As shown by table 16 , approximately 36 million trees were estimated to be suitable for poles or piles, of which half were in the 20 -foot class, 35 percent in the 25-foot and 30-foot classes, and less than 15 percent were at least 35 feet long.

Approximately 38 percent of the trees with pole or pile qualifications are round slash and longleaf, 54 percent are longleaf and slash pine trees being worked for naval stores, and 8 percent are nonturpentine pine. No attempt is made, however, to show what part of this resource is actually available 
for this use. The lumber and other well-established wood-using industries must be supplied with raw materials and are constantly converting pole and pile timber into other commodities. Also the rapidly developing market for pulpwood may further increase the competition for pole trees.

The saw-timber, cordwood, and cubic volumes of these pole and pile trees are included in tables 11 to 15 , and do not constitute an additional volume item.

TABLE 16.--Pole and pile resources, 1 by tree diameter classes and lengths of product, 1934

\begin{tabular}{|c|c|c|c|c|c|c|c|c|c|c|}
\hline Tree-diameter class (inches)? & 20 feet & 25 feet & 30 feet & 35 feet & 40 feet & 45 feet & 50 feet & 55 feet & \multicolumn{2}{|c|}{ All lengths } \\
\hline 7.0 to 8.9 & $\begin{array}{l}1,000 \\
\text { sticks } \\
\quad 8,453\end{array}$ & $\begin{array}{l}1,000 \\
\text { sticks } \\
2,314\end{array}$ & $\begin{array}{l}1,000 \\
\text { sticks } \\
982\end{array}$ & $\begin{array}{l}1,000 \\
\text { sticks } \\
188\end{array}$ & $\begin{array}{l}1,000 \\
\text { sticks }\end{array}$ & $\begin{array}{l}1,000 \\
\text { sticks }\end{array}$ & $\begin{array}{l}x, 000 \\
\text { sticiss }\end{array}$ & $\begin{array}{l}1,000 \\
\text { sticks }\end{array}$ & $\begin{array}{l}1,000 \\
\text { sticks } \\
11,937\end{array}$ & $\begin{array}{r}\text { Percent } \\
33.0\end{array}$ \\
\hline 9.0 to 10.9 & 5,155 & 2,276 & 1,203 & 682 & 339 & 35 & & & 9,690 & 26.8 \\
\hline 11.0 to $12.9 \ldots$ & 2,921 & 1,828 & 1,126 & 855 & 567 & 142 & 32 & & 7,471 & 20.7 \\
\hline 13.0 to 14.9 & 1,188 & 1,027 & 780 & 608 & 404 & 197 & 75 & 22 & 4,301 & 11.9 \\
\hline 15.0 to 16.9 & 316 & 422 & 419 & 335 & 201 & 112 & 75 & 47 & 1,927 & 5.3 \\
\hline \multirow[t]{3}{*}{17.0 to 18.9} & 43 & 162 & 222 & 169 & 100 & 60 & 34 & 44 & 834 & 2.3 \\
\hline & 18,076 & 8,029 & 4,732 & 2,837 & 1,611 & 546 & 216 & 113 & 36,160 & \\
\hline & $\begin{array}{r}\text { Percent } \\
50.0\end{array}$ & $\begin{array}{r}\text { Percent } \\
22.2\end{array}$ & $\begin{array}{r}\text { Percent } \\
13.1\end{array}$ & $\begin{array}{r}\text { Percent } \\
7.8\end{array}$ & $\begin{array}{r}\text { Percent } \\
4.5\end{array}$ & $\begin{array}{r}\text { Percent } \\
1.5\end{array}$ & $\begin{array}{r}\text { Percent } \\
.6\end{array}$ & $\begin{array}{r}\text { Percent } \\
-3\end{array}$ & & 100.0 \\
\hline
\end{tabular}

1 Round and turpentined longleaf and slash pines and loblolly pine. Poles and piles of saw-timber size are included in saw-timber volume and all sizes in the cordwood and cubic-foot volumes. Material recorded here does not constitute additional volume.

${ }^{2}$ Measurements were based on diameters outside bark at $41 / 2$ feet above ground; this is roughly equiralent to inside bark measurement at stump height.

\section{Pulproood}

Because of the growing interest in the use of southern pines and soft-textured hardwoods for kraft and other papers, and the increasing demand for information concerning the timber resources in this area, the total volume of all species generally used for pulping is shown in cords in table 17 by species groups and quality classes. The sound trees are divided into two size classes to indicate the amount in large sizes which may have more value for products other than pulpwood. These volume estimates, which include all trees of pulping species 5 inches d. b. h. and larger, regardless of suitability for higher use, also are included in the previous tables and are not to be considered as additional volumes. Furthermore, not all of this material is available for pulping at the present time: much of it is in trees that are more valuable for saw timber, poles, ties, or other products than for pulp-

TABLE 17.-Net cordwood volume of pulping species, by quality classes, 1934

\begin{tabular}{|c|c|c|c|c|c|c|}
\hline \multirow{2}{*}{ Pulping species group } & \multirow{2}{*}{$\begin{array}{c}\text { Sound trees } \\
5-13 \text { inches } \\
\text { d.b.b. }\end{array}$} & \multicolumn{2}{|c|}{$\begin{array}{c}\text { Sound trees } 14.0 \text { inches } \\
\text { d.h.h. and larger }\end{array}$} & \multirow{2}{*}{ Cull trees 2} & \multirow{2}{*}{\multicolumn{2}{|c|}{ AIl quality olasses }} \\
\hline & & $\begin{array}{l}\text { Sawlog } \\
\text { material }\end{array}$ & $\begin{array}{l}\text { Tops and } \\
\text { limbs } ?\end{array}$ & & & \\
\hline \multicolumn{7}{|l|}{ Pines: } \\
\hline $\begin{array}{c}\text { Turpentine: } \\
\text { Round }\end{array}$ & $\begin{array}{l}\text { Cords } \\
13,781,700\end{array}$ & $\begin{array}{l}\text { Cords } \\
2,047,700\end{array}$ & $\begin{array}{l}\text { Cords } \\
289,700\end{array}$ & $\begin{array}{l}\text { Cords } \\
\quad 60,900\end{array}$ & $\begin{array}{l}\text { Cords } \\
16,180,000\end{array}$ & $\begin{array}{r}\text { Percent } \\
17.1\end{array}$ \\
\hline Working and resting & $13,145,200$ & $4,415,400$ & $1,516,700$ & 57,800 & $19,135,100$ & 20.3 \\
\hline Worked-out & $3,426.200$ & $1,749,000$ & 574,100 & 64,600 & $5,813,900$ & 6.1 \\
\hline Nonturpentine & $6,049,900$ & $6,775,400$ & $1,005,700$ & 219,300 & $14,050,300$ & 14.8 \\
\hline Total & $36,403,000$ & $14,987,500$ & $3,386,200$ & 402,600 & $55,179,300$ & 58. 3 \\
\hline Soft-textured hardwoods ${ }^{3}$ & $13,848,200$ & $8,562,100$ & $4,491,000$ & $6,736,100$ & $33,637,400$ & 35.6 \\
\hline Cypress...................... & $3,411,200$ & $1,210,900$ & 451,500 & 676,800 & $5,750,400$ & 6. 1 \\
\hline & $53,662,400$ & $24,760,500$ & $8,328,700$ & $7,815,500$ & $94,567,100$ & \\
\hline All pulping species... & Percent & Percent & Percent & Percent & & \\
\hline & 56.7 & 26. 2 & 8. 8 & 8.3 & & 100.0 \\
\hline
\end{tabular}

1 Includes turpentined butt sections in sawlog-size trees that are not considered suitable for board-foot material.

2 Sound material in cull trees.

See p. 4 for list of species included. 
wood; much of it is in trees that are now too small for these commodities but that constitute the growing stock for the future supply; and much of it is in working longleaf and slash pines or in round trees that will undoubtedly be turpentined before being cut for wood products. Industries dependent upon pulpwood must appreciate, therefore, that only a small part of the volume shown in table 17 is free from competitive requirements of other consumers and can be used for pulpwood without reducing the growing stock and seriously endangering the continuity of the future timber supply in the area.

From the viewpoint of the conservationist, the pulpwood supply in south Georgia would come logically from the worked-out turpentine pines, from cull trees, from trees of inferior species, from thinnings of dense stands, and from the salvage of material usually wasted in the cutting of other products. Approximately 32 percent of the turpentine area, or over $2 \frac{1}{2}$ million acres, was classified as worked-out or resting. On this area and on the area being worked for naval stores almost 6 million cords of worked-out naval stores timber has accumulated that has little value (or prospect of utilization) other than for pulpwood products, and each year a million cords are being added. Nearly 7 million cords, or 86 percent, of the total cordwood volume in cull trees is in the tupelos, sweetgum, southern sweetbay, red maple, southern magnolia, and other soft-textured hardwocds. Recent trends point to their fuller use in the future.

A steady market for pulpwood should justify more intensive management, whereby thinnings and improvement cuttings and salvage of waste might be made profitably. Furthermore, the utilization of worked-out naval stores pines and cull trees would make room for reproduction and at the same time stimulate growth on the opened stands.

\section{Forest Increment}

The annual increment, as considered in this report, is the difference between the volume of the sound-tree stand at the beginning of a year, and the corresponding volume at the end of the year before deducting for commodity drain during that period. This difference in stand volume is a result of the interaction of growth and mortality.

Natural factors which influence the rate of growth of each species are site quality, density of stand, forest condition, and age. Factors which contribute to mortality are fire, insects, disease, windstorms, turpentining, and natural crowding. It is assumed that once a tree is cupped for naval stores it will continue to be used for this purpose until worked out. That portion of the turpentine butt volume which eventually will be lost as a result of turpentining is therefore deducted from the growth when the cup is first hung.

\section{Board-foot and Cordwood Increment}

The net board-foot and cordwood increments for 1934 are classified according to forest condition and species group in table 18. The board-foot increment includes the volume of those trees that reach saw-timber size during the year, plus the increase in volume of trees of saw-timber size, less the volume of saw-timber trees which died during the year. The cordwood increment similarly includes the

TABLE 18.--Net increment, classified according to forest condition and species group, 1934

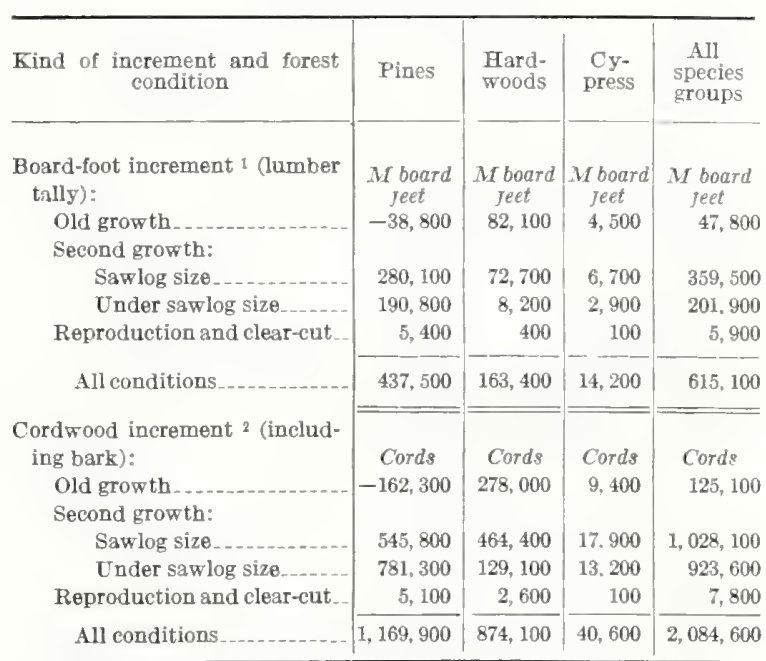

1 Net increases in volume of saw-timber material.

a Net increases in saw-timber material and upper stems of sawlog size pines; also in sound trees 5 inches d. b. h. and up to saw log size.

TABLE 19.-Net increment classified according to species group, $1934-36$

\begin{tabular}{|c|c|c|c|c|}
\hline Kind of increment and year & Pine & $\begin{array}{l}\text { Hard- } \\
\text { wood }\end{array}$ & $\begin{array}{l}\mathrm{Cy} \cdot \\
\text { press }\end{array}$ & $\begin{array}{c}\text { All } \\
\text { species }\end{array}$ \\
\hline $\begin{array}{l}\text { Board-foot increment (lum- } \\
\text { ber tally): } \\
1934 \\
1935 \\
1936\end{array}$ & $\begin{array}{l}M \text { board } \\
\text { feet } \\
437,500 \\
468,900 \\
458,900\end{array}$ & $\begin{array}{l}M \text { board } \\
\text { feet } \\
163,400 \\
163,900 \\
164,200\end{array}$ & $\begin{array}{l}\text { M board } \\
\text { feet } \\
14,200 \\
14,200 \\
14,300\end{array}$ & $\begin{array}{l}M \text { board } \\
\text { feet } \\
615,100 \\
647,000 \\
637,400\end{array}$ \\
\hline $\begin{array}{l}\text { Cubic-foot increment (inside } \\
\text { bark): } \\
\quad 1934 \\
1935 \\
1936\end{array}$ & $\begin{array}{l}\text { M cubic } \\
\text { feet } \\
81,010 \\
95,930 \\
98,100\end{array}$ & $\begin{array}{l}\text { M cubic } \\
\text { feet } \\
56,450 \\
57,910 \\
58,450\end{array}$ & $\begin{array}{l}\text { Mcubic } \\
\text { feet } \\
2,900 \\
2,950 \\
2,990\end{array}$ & $\begin{array}{l}\text { M cubic } \\
\text { feet } \\
140,360 \\
156,790 \\
159,540\end{array}$ \\
\hline
\end{tabular}


TABLE 20.-Average increment per acre, shown in board feet, cubic feet, and cords, 1934 (uninfluenced by cutting)

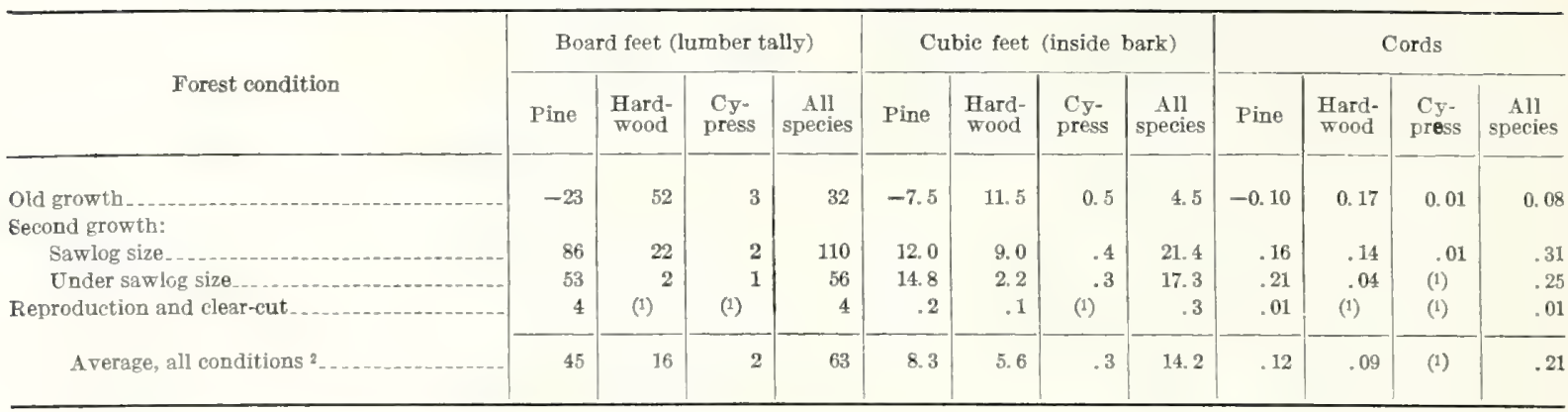

1 Negligible.

${ }^{2}$ The average increment, per acre for all conditions except reproduction and clear-cut for 1934 are: board feet, 72 ; cubic feet, $16.5 ;$ and cords, 0.24 .

increase in volume of all trees 5.0 inches d. b. h. and larger, plus the volume of those trees reaching 5.0 inches $\mathrm{d} . \mathrm{b}$. h. during the year, minus mortality. Growth prior to cutting of trees removed from the stand during the year has been included.

Table 19 shows the increment, all conditions combined, in board feet and cubic feet (inside bark) by species groups for the 3-year period 1934-36.

\section{Average Increment per Acre}

The average increment for 1934, uninfluenced by cutting (table 20), for the entire area and for all species groups combined amounts to 63 board feet of saw-timber material per acre, or one-fifth cord of all material. Since in calculating the increment per acre it is assumed that no trees are removed from the stand for commodity drain during the year, the figures are slightly higher than those which may be derived from table 18, where only the growth prior to cutting was taken into account for trees removed.

\section{Effect of Turpentining on Increment}

Although longleaf and slash pine have the advantages of dual-purpose trees, those turpentined pay a very heavy toll in reduced increment. Deep chipping, inserting tins too deeply, cupping small trees, overcupping, and failing to protect resting or worked-out trees from fire have retarded the diameter growth of the individual trees, reduced their volume of merchantable timber, and increased the number of trees lost through insects, wind throw, and fire. Fires have prevented much of the area from fully restocking.

Board-foot and cordwood comparisons of the actual growth of the timber when turpentined with that of the timber if it had been left round, are given in table 21. The actual mortality of the timber when turpentined and the mortality of the same timber if left round is also listed, together with the volume of turpentine butts that it is assumed will be lost during the working period of the virgin crops hung in 1934.

TABLE 21.-Effects of turpentining on forest increment, $1934^{1}$

\begin{tabular}{|c|c|c|c|c|c|c|}
\hline & \multicolumn{2}{|c|}{ If left round } & \multicolumn{2}{|c|}{ As turpentined } & \multicolumn{2}{|c|}{$\begin{array}{l}\text { Turpentining } \\
\text { net loss }\end{array}$} \\
\hline $\begin{array}{l}\text { Growth } \\
\text { Mortality } \\
\text { Loss in butt vol- } \\
\text { ume. }\end{array}$ & $\begin{array}{c}M \text { board } \\
\text { feet } \\
657,300 \\
107,200\end{array}$ & $\begin{array}{c}M \text { cords } \\
1,367 \\
319\end{array}$ & $\begin{array}{c}M \text { board } \\
\text { feet } \\
342,600 \\
407,500\end{array}$ & $\begin{array}{c}M \text { cords } \\
849 \\
1,675\end{array}$ & 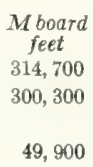 & $\begin{array}{r}M \text { cords } \\
518 \\
1,356\end{array}$ \\
\hline Total loss & & & & & 664,900 & 1,949 \\
\hline
\end{tabular}

1 Board-foot volumes expressed as lumber tally, based on International 1/4-inch rule.

The working of small trees under 9 inches d. b. h., along with the accompanying excessive mortality, not only is responsible for a large share of the negative increment in cords, but also reduces the possibility of a future cut of high-quality timber and endangers the stability of those industries dependent upon saw timber. Under improved naval stores practices, adequate fire protection, more intensive forest management, and improved utilization, the enormous loss in 1934 of approximately 665 million board feet, lumber tally, or almost 2 million cords of material of all sizes (table 21) could have been reduced appreciably. Such reduction is most desirable in order that there may be more timber for the wood-using industries, which furnish muchneeded jobs and add to the general wealth of the community. 


\section{Wood-Products Industries and Drain}

The industries producing lumber and other wood products have been an important factor in the development of Georgia since the close of the eighteenth century. At first they were confined to the main rivers and along the coast, helping to develop such ports as Savannah, Brunswick, and Darien; squared pine and cypress timbers for export and live oak for ship timbers were the principal products. With the introduction of more modern transportation facilities and equipment, lumber production in the State expanded from a comparatively unimportant cut by relatively few small water-powered and steam sawmills in 1820 to 1.3 billion board feet in 1899. A peak of approximately 1.4 billion board feet was reached in 1925 and again in 1929. The lowest recorded production for the State in the present century was during the depression year of 1932, when only 264 million board feet was reported.

To meet the needs of the developing railroads, the cross-tie industry flourished and became an important factor in forest utilization. Similarly the growth of the naval stores, fruit, and vegetable industries stimulated the manufacture of barrels, crates, hampers, boxes, and other containers.

In 1936 the board-foot drain occasioned by the various wood-products industries in south Georgia amounted to 707 million feet, which caused a total drain, including incidental waste, of nearly 149 million cubic feet. Almost 4 million mandays of employment (the equivalent of approximately 26,000 men working 150 days each) were furnished by these industries. The large number of plants (fig. 27) dependent upon the forest resources indicates the importance of, and vital need for, those better forest practices that not only will increase the productive capacity but also will insure the economic stability of this area.

\section{Lumber}

Lumber production in south Georgia increased from approximately 228 million board feet in 1934 to almost 277 million feet in 1935. By 1936 the cut had increased another 50 million feet (table 22); 82 percent of the total cut was pine, 12 percent hardwood, and 6 percent cypress.

During 1936, of 343 sawmills in south Georgia,
TABLE 22.-Production and employment in the wood-products industries, 7936

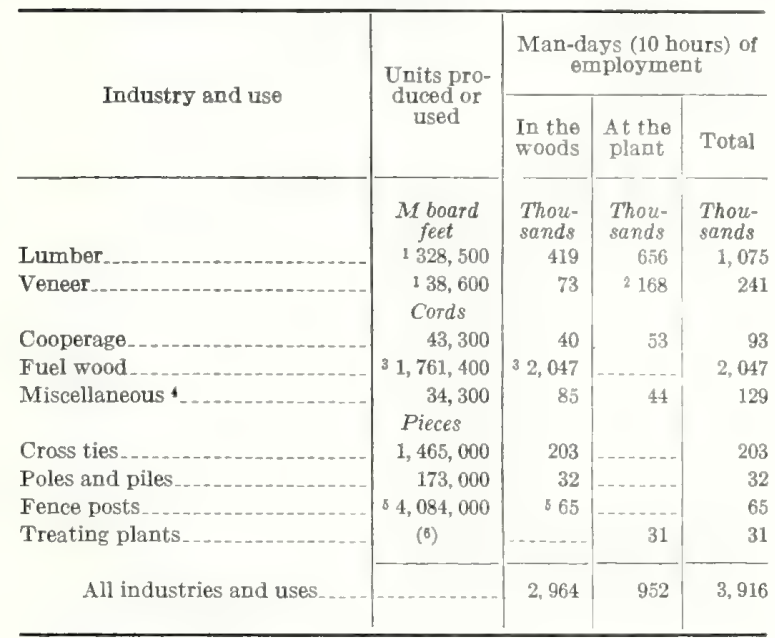

1 Lumber tally.

${ }_{2}$ Includes fabrication in crate and package plants.

${ }^{3}$ Includes 166,600 cords of commercial fuel wood; also includes 50,600 cords of fuel wood used in stilling operations, but the labor for this is accounted for in the section on Gum Naval Stores Industry.

Includes pulpwood, shingle mills, ete.

B Includes 400,000 commercial fence posts, on which 6,000 man-days of labor were expended.

- The units of material treated are included in the respective commodities.

TABLE 23.- Number of sawmills, classified according to species cut and capacity, 1936

\begin{tabular}{c|r|r|r}
\hline $\begin{array}{c}\text { Daily (10-hour) capacity } \\
(\text { M board feet) }\end{array}$ & Pine & $\begin{array}{c}\text { Hard- } \\
\text { wood }\end{array}$ & \multicolumn{1}{c}{$\begin{array}{c}\text { All } \\
\text { species }\end{array}$} \\
\hline Under 20 & 310 & & 310 \\
20 to 39. & 20 & 10 & 30 \\
40 and over & 3 & 3 \\
\hline All mills. & 333 & 10 & 343 \\
\hline
\end{tabular}

90 percent were small, with a daily capacity of less than 20,000 board feet (table 23), and many were intermittently operated. There were no mills with a daily capacity of 80,000 board feet or more.

More than 1 million man-days of employment were furnished by the lumber industry in 1936 in both the woods and mills. While a few of the mills were operating in large tracts of timber, most of them were dependent for logs on small scattered bodies of second-growth timber.

Truck logging is almost universal; only a few operators transport their logs by tram or water. Truck logging is most effective within a radius of 30 miles of a mill and often results in the logging of isolated patches of only a few trees. 


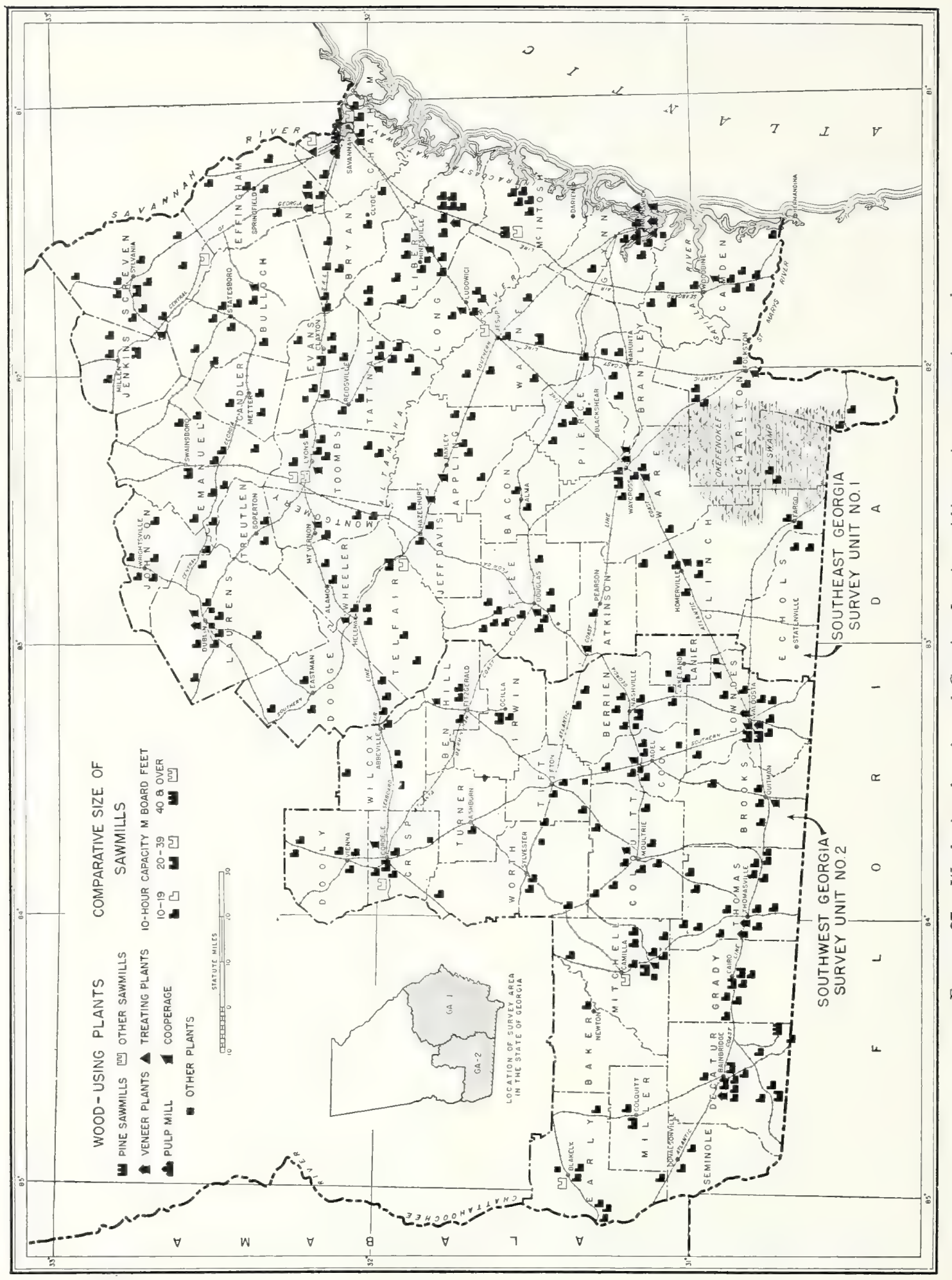


TABLE 24.-Commodity drain from saw-timber growing stock, and from all sound trees 5 inches d. b. h. and larger, 1936

FROM SAW-TIMBER GROWING STOCK (LUMBER TALLY)

\begin{tabular}{|c|c|c|c|c|c|}
\hline Commodity & Pine & $\begin{array}{l}\text { Hard- } \\
\text { wood }\end{array}$ & $\begin{array}{l}\text { Cy- } \\
\text { press }\end{array}$ & \multicolumn{2}{|c|}{ All species } \\
\hline Lumber & $\begin{array}{c}\begin{array}{c}M \text { board } \\
\text { feet } \\
274,000\end{array}\end{array}$ & $\begin{array}{c}M \text { board } \\
\text { feet } \\
52,100\end{array}$ & $\begin{array}{c}M \text { board } \\
\text { feet } \\
14,300\end{array}$ & $\begin{array}{c}\text { Mboard } \\
\text { feet } \\
340,400\end{array}$ & $\begin{array}{r}\text { Percent } \\
48.2\end{array}$ \\
\hline Veneer...... & 10,900 & 29,300 & & 40,200 & 5. 7 \\
\hline Cooperage & 16,400 & 2,100 & & 18,500 & 2.6 \\
\hline Pulpwood & 16,200 & & & 16,200 & 2.3 \\
\hline Cross ties & 31,000 & 7,200 & 56,900 & 95,100 & 13.4 \\
\hline Poles and piles. & 13,400 & & 600 & 14,000 & 2.0 \\
\hline Fence posts . . . . & & & & & \\
\hline Fuel wood & 124,300 & 46,400 & & 170,700 & 24.1 \\
\hline Miscellaneous 1_. & 8,200 & 3,700 & ${ }^{(2)}$ & 11,900 & 1.7 \\
\hline All commodities.. & 494,400 & 140,800 & 71,800 & 707,000 & 100.0 \\
\hline
\end{tabular}

FROM SOUND TREES 5.0 INCHES D. B. H. AND LARGER (INSIDE BARK)

\begin{tabular}{|c|c|c|c|c|c|}
\hline Lumber & $\begin{array}{c}\text { M cubic } \\
\text { feet } \\
57,350\end{array}$ & $\begin{array}{c}M \text { cubic } \\
\text { feet } \\
7,870\end{array}$ & $\begin{array}{c}M \text { cubic } \\
\text { feet } \\
2,020\end{array}$ & $\begin{array}{c}\text { M cubic } \\
\text { feet } \\
67,240\end{array}$ & $\begin{array}{r}\text { Percent } \\
45.3\end{array}$ \\
\hline Veneer & 2,010 & 4,190 & & 6,200 & 4. 2 \\
\hline Cooperage & 3,740 & 340 & & 4,080 & 2.8 \\
\hline Pulpwood... & 5,780 & & & 5,780 & 3. 9 \\
\hline Cross ties & 6,150 & 1,090 & 8,570 & 15,810 & 10.6 \\
\hline Poles and piles & 2,930 & & 100 & 3,030 & 2.0 \\
\hline Fence posts ${ }^{3} \ldots$ & 360 & 220 & 220 & 800 & .5 \\
\hline Fuel wood & 32,190 & 9,150 & & 41,340 & 27.8 \\
\hline Miscellaneous ${ }^{1}$ & 3,210 & 1,040 & $\left({ }^{2}\right)$ & 4,250 & 2.9 \\
\hline All commodities... & 113,720 & 23,900 & 10,910 & 148,530 & 100.0 \\
\hline
\end{tabular}

1 Includes shingles, dimension stock, export logs, material employed in domestic farm use, and drain incidental to land clearing.

${ }^{2}$ Negligible.

${ }^{3}$ Includes only fence posts cut from growing-stock material, roughly one-third of the total number cut.

"Commodity drain," as used in this report, represents the volume of timber cut from forest stands within the unit to meet the requirements of sawmills and other wood-using plants and activities. It differs from actual production to the extent of the amount of woods waste incidental to manufacture and incomplete economic utilization, the volume in trees cut within the unit but manufactured outside it, and the volume of trees cut outside the unit but manufactured within it. The sawtimber drain for lumber production in 1936 was more than 340 million board feet, and caused a total drain of more than 67 million cubic feet (table 24).

\section{Veneer}

In 1934 the veneer industry of south Georgia used the equivalent of approximately 46 million board feet (lumber tally). Eleven rotary-cut veneer plants used between 35 and 40 million board feet in 1935 and 1936. In 1936, this caused a drain of more than 6 million cubic feet and furnished approximately 241,000 man-days of employment. Nine of these plants are parts of establishments manufacturing fruit and vegetable boxes, crates, hampers, and baskets; two also manufacture plywood veneers. The principal woods used are pine, black and water tupelo, sweetgum, yellowpoplar, southern magnolia, and sweetbay. Three container plants log their own timber, while the remainder buy logs delivered at the plant.

\section{Cooperage}

Most of the 28 stave plants are in southeast Georgia, where many of them make rosin barrels from pine; a few make hardwood staves or slack barrel heads and hamper bottoms and tops. Several plants log their own timber, while the remainder buy blocks delivered at the mill. This industry uses approximately 40,000 cords of pine and 3,000 cords of hardwood annually, which caused a drain of approximately 4 million cubic feet in 1936 and furnished about 93,000 man-days of employment.

\section{Piece Products}

Approximately 155,000 pine and 5,000 cypress poles and piles were produced in 1934. Production fell off slightly in 1935 but increased in 1936 to about 159,000 pine and 14,000 cypress poles, causing a total drain of more than 3 million cubic feet. In 1936 this industry furnished approximately 32,000 man-days of employment.

Approximately 2 million cross ties (sawed and hewn) were produced both in 1934 and 1935, while in 1936 production fell off to approximately $1 \frac{1}{2}$ million, of which 56 percent was cypress, 36 percent pine, and 8 percent hardwood. The 1936 requirement of the cross-tie industry in sawlog-size timber was about 95 million board feet, which is equivalent to a drain of almost 16 million cubic feet, or 11 percent of the total drain. This important industry furnished part-time employment totaling about 203,000 man-days in 1936 and involved utilization of scattered tracts of timber, most of them unpractical for timber production. (Fig. 28.) 


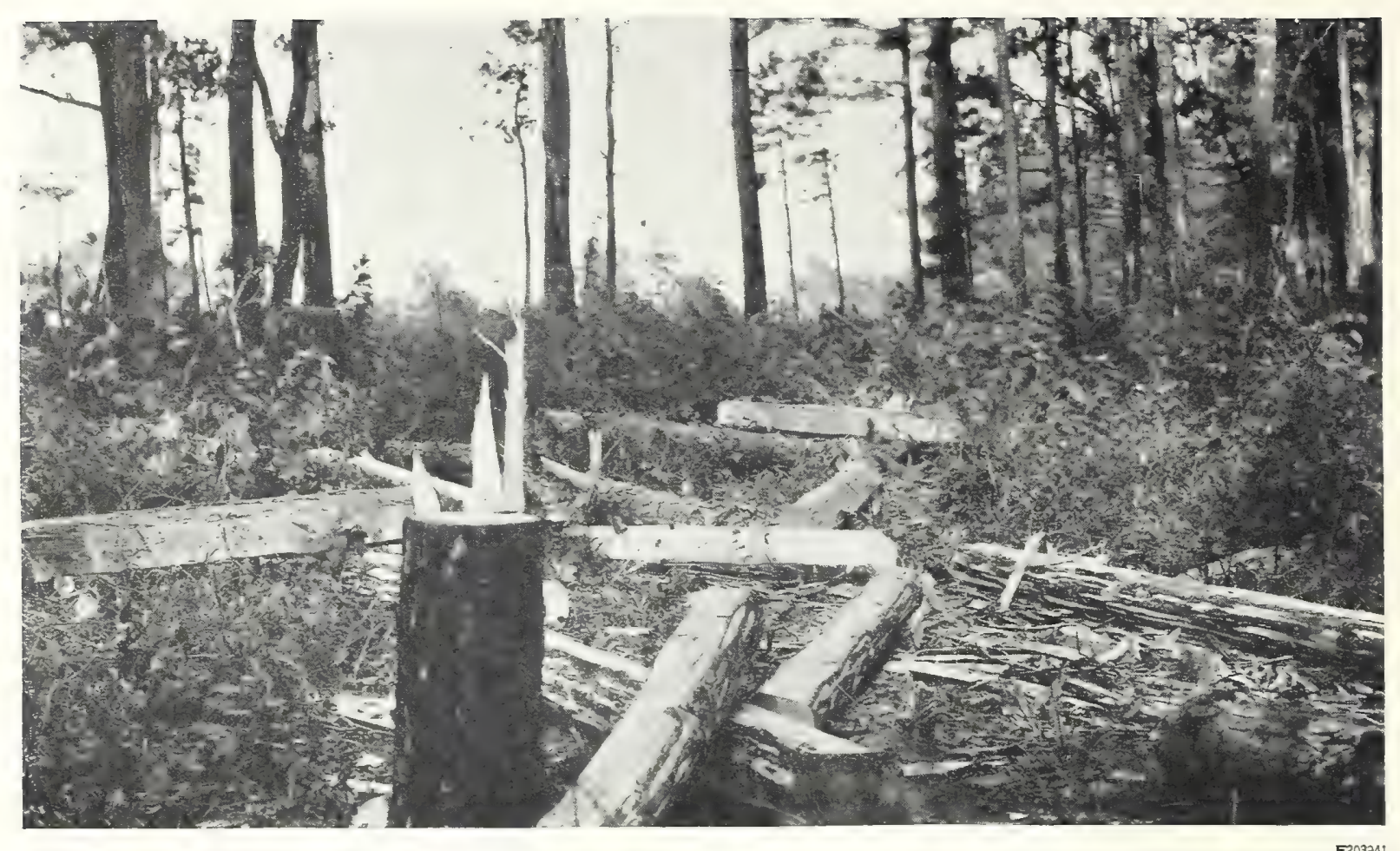

FIGURE 28.-A typical operation for hewn cross ties. Such operations afford opportunities for part-time employment and for utilization of scattered tracts of timber.

Approximately 4 million fence posts are produced in this area annually, furnishing about 65,000 mandays of employment. Most of the posts come from lightwood (i. e., dead pine heartwood) and dead cypress heartwood, only 800,000 cubic feet being considered as drain against the sound-tree inventory.

\section{Pulprood}

In 1934 the pulpwood market for south Georgia was restricted to one mill in adjacent Florida, but during the period 1935-38 several new kraft pulp and paper mills were established in the South, two of which were located on the Atlantic coast in south Georgia. The mill at Savannah started production in 1936 and the one at Brunswick early in 1938. Although the Savannah mill drew part of its requirements from adjacent South Carolina, the pine pulpwood drain on south Georgia in 1935 and 1936 amounted to approximately 47,000 and 77,000 cords, respectively. When operating full time, the two mills in south Georgia will consume about 400,000 cords of wood annually and will furnish approximately 1 million man-days of employment. Four new pulp mills located nearby in Florida may draw a considerable portion of their annual requirements of almost one-half million cords from south Georgia.

\section{Fuel Wood}

A large rural population, the lack of natural gas, and the distance from coal fields cause an extremely heavy fuel-wood demand. Most of the fuel wood is consumed for domestic purposes, while approximately 220,000 cords are used commercially in turpentine stilling, cotton ginning, sirup making, tobacco curing, etc. About $1 \frac{3 / 4}{4}$ million cords of fuel wood are used annually. Only 560,000 cords, or 41 million cubic feet, are drain from the growing stock; the non-drain fuel wood is principally dead and down timber and fat pine lightwood.

\section{Miscellaneous}

In 1936 the miscellaneous production, including logs exported, material used locally on farms, and 
the cut of shingle and small-dimension mills, amounted to approximately 43,000 cords, resulting in a drain of 3.5 million cubic feet. The drain caused by land clearing averages slightly more than 700,000 cubic feet annually.

\section{Comparison of Increment With Commodity Drain}

The growth and drain data given in previous sections have been reassembled here in order that that they may be compared and their net influence upon the growing stock of the area considered. The inventory data previously given were based on field work in 1934. Changes produced by growth, mortality, turpentining, and commodity drain indicate that during 1934 and 1935 the pine sawtimber increment exceeded the drain, thereby increasing the growing stock; but because of the increased forest-industry activity in 1936, the pine saw-timber drain exceeded the increment, reducing the growing stock by more than 35 million board feet (table 25).

TABLE 25.-Change in growing stock, 1934-37

IN BOARD FEET (LUMBER TALLY)

\begin{tabular}{|c|c|c|c|c|}
\hline Item & Pine & $\begin{array}{l}\text { Hard- } \\
\text { wood }\end{array}$ & $\begin{array}{r}\text { Cy- } \\
\text { press }\end{array}$ & $\begin{array}{c}\text { All } \\
\text { species }\end{array}$ \\
\hline & $\begin{array}{c}M \text { board } \\
\text { jeet }\end{array}$ & $\underset{\text { jeet }}{M \text { board }}$ & $\mid \begin{array}{c}M \text { board } \\
\text { jeet }\end{array}$ & $\begin{array}{c}M \text { board } \\
\text { jeet }\end{array}$ \\
\hline Growing stock, Jan. 1, 1934 & $112,625,500$ & $4,910,900$ & $1,033,200$ & $18,569,600$ \\
\hline Change in growing stock & 22,100 & 38,000 & $-89,900$ & $-29,800$ \\
\hline Growing stock, Jan. 1, 1935.. & $12,647,600$ & $4,948,900$ & 943,300 & $18,539,800$ \\
\hline Change in growing stock. & 20,500 & 33,700 & $-83,300$ & $-29,100$ \\
\hline Growing stock, Jan. 1, 1936 & $12,668,100$ & $4,982,600$ & 860,009 & $18,510,700$ \\
\hline Change in growing stock & $-35,500$ & 23,400 & $-57,500$ & $-69,600$ \\
\hline Growing stock, Jan. 1, 1937 .- & $12,632,600$ & $5,006,000$ & 802,500 & $18,441,100$ \\
\hline
\end{tabular}

IN CUBIC FEET (INSIDE BARK)

\begin{tabular}{|c|c|c|c|c|}
\hline & $\underset{\text { jeet }}{M \text { cubic }}$ & $\begin{array}{c}\text { yect } \\
\text { ject }\end{array}$ & $\begin{array}{c}M \text { cubic } \\
\text { jeet }\end{array}$ & $\begin{array}{c}M \text { cubic } \\
\text { feet }\end{array}$ \\
\hline Grow ing stock, Jan. 1, 1934 & $24,070,480$ & $1,914,180$ & 312,960 & $26,297,620$ \\
\hline Change in growing stock & $-10,370$ & 33,930 & $-12,770$ & 10,790 \\
\hline Growing stock, Jan. 1, 1935_- & $4,060,110$ & $1,948,110$ & 300,190 & $6,308,410$ \\
\hline Change in growing stock. & $-7,010$ & 35,620 & $-11,870$ & 16,740 \\
\hline Growing stock, Jan. 1, 1936 & $4,053,100$ & $1,983,730$ & 288,320 & $6,325,150$ \\
\hline Change in growing stock. & $-15,620$ & 34,550 & $-7,920$ & 11. 010 \\
\hline Growing stock, Jan. 1, $1937 \ldots$ & $4,037,480$ & $2,018,280$ & 280,400 & $6,336,160$ \\
\hline
\end{tabular}

1 Includes $49,900 \mathrm{M}$ board feet in the butts of newly cupped trees not shown in the inventory summarized in tables 13,14 , and 15 .

Includes $5,630 \mathrm{M}$ cubic feet in the butts of newly cupped trees not shown in the inventory summarized in table 17.
TABLE 26.-Comparison of increment with commodity drain, 1936 IN BOARD FEET, LUMBER TALLY

\begin{tabular}{|c|c|c|c|c|}
\hline Item & Pine & $\begin{array}{l}\text { Hard- } \\
\text { wood }\end{array}$ & $\begin{array}{l}\mathrm{Cy}- \\
\text { press }\end{array}$ & $\underset{\text { species }}{\text { All }}$ \\
\hline & $\begin{array}{c}M \text { board } \\
\text { feet }\end{array}$ & $\begin{array}{c}M \text { board } \\
\text { feet }\end{array}$ & $\underset{\substack{\text { board } \\
\text { feet }}}{M}$ & $\begin{array}{c}M \text { bourd } \\
\text { jeet }\end{array}$ \\
\hline Growing stock, Jan. 1, 1936_..- & $12,668,100$ & $4,982,600$ & 860,000 & $18,510,700$ \\
\hline Growth & $1,015,800$ & 233,300 & 21,300 & $1,270,400$ \\
\hline Mortality & \multirow[t]{2}{*}{515,400} & \multirow[t]{2}{*}{69,100} & \multirow[t]{2}{*}{7,000} & 591,500 \\
\hline $\begin{array}{l}\text { Loss in butt volume (with- } \\
\text { drawn for naval stores) }\end{array}$ & & & & 41,500 \\
\hline Total loss... & 556,900 & 69,100 & 7,000 & 633,000 \\
\hline Net increment.......... & 458,900 & 164,200 & 14,300 & 637,400 \\
\hline Commodity drain & 494,400 & 140,800 & 71,800 & 707,000 \\
\hline $\begin{array}{l}\text { Net change in growing } \\
\text { stock }\end{array}$ & $-35,500$ & 23,400 & $-57,500$ & $-69,600$ \\
\hline Growing stock, Jan. 1, $1937 \ldots$ & $12,632,600$ & $5,006,000$ & 802,500 & $18,441,100$ \\
\hline
\end{tabular}

IN CUBIC FEET (INSIDE BARK)

\begin{tabular}{|c|c|c|c|c|}
\hline Growing stock, Jan, 1, 1936 & $\begin{array}{c}M \text { cubic } \\
\text { feet } \\
4,053,100\end{array}$ & $\begin{array}{c}M_{\text {feut }} \\
1,983,730\end{array}$ & $\begin{array}{c}M \text { cubic } \\
\text { jett } \\
288,320\end{array}$ & $\begin{array}{l}M \text { cubic } \\
\quad \text { feet } \\
6,325,150\end{array}$ \\
\hline Growth & 254,920 & 92,470 & 5,880 & 353,270 \\
\hline Mortality ................ & 152,730 & 34,020 & 2,890 & 189,640 \\
\hline $\begin{array}{l}\text { Loss in butt volume (with- } \\
\text { drawn for naval stores) }\end{array}$ & 4,090 & & & 4,090 \\
\hline Total loss & 156,820 & 34,020 & 2,890 & 193,730 \\
\hline Net increment. & 98,100 & 58,450 & 2,990 & 159,540 \\
\hline Commodity drain & 113,720 & 23,900 & 10,910 & 148,530 \\
\hline $\begin{array}{l}\text { Net change in growing } \\
\text { stock }\end{array}$ & $-15,620$ & 34,550 & $-7,920$ & 11,010 \\
\hline Growing stock, Jan. 1, 1937__-_ & $4,037,480$ & $2,018,280$ & 280,400 & $6,336,160$ \\
\hline
\end{tabular}

In the hardwood stands increment exceeded the drain during each of the 3 years analyzed, but the cut was from the more valuable species and sizes and the major portion of the increment occurred on younger, second-growth timber of low value and on less-desirable species. Cypress drain exceeded increment each of the years studied and caused a reduction in growing stock of more than 230 million board feet between January 1, 1934, and January 1, 1937.

For all species-groups combined, the growing stock was reduced more than 29 million board feet per year during 1934 and 1935. In 1936 the decrease in growing stock amounted to almost 70 million board feet. Although the pine and cypress growing stock shows a decrease in cubic-foot 
volume each year, the increase in hardwoods more than offsets this loss, and for all species and sizes combined the growing stock is increasing in volume if not in value.

Table 26 shows both board-foot and cubic-foot growing stock as of January 1, 1936, the changes taking place during the year, and the growing stock as of January 1, 1937, for the various species groups. The heavy mortality in pine occurred chiefly in the turpentined stands, where mortality exceeded growth. Nonturpentine pine species are being heavily overcut, and indications are that this is partly due to a purposeful reduction of their competition with the more valuable dual-purpose turpentine pines. The unfavorable balance in cypress is due to the combined effects of slow growth, the heavy cut in old-growth timber, and the failure of cypress to restock the area. Because of the favorable balance in the hardwood species, the cubic-foot comparison of increment with drain for all species combined in 1936 showed a surplus of more than
11 million cubic feet. Although there was an increase of nearly 35 million cubic feet of hardwoods, the deficit of almost 16 million cubic feet of pine and of 8 million of cypress brings about an unfavorable condition.

Under improved forest management the ratio of growth to drain could be made much more favorable, and the supply of wood for industry could be increased greatly. Adequate protection from fire is the first and most important need to improve the situation. This should result in much better stocking. In addition, open areas should be reforested to utilize the land more fully and to build up the depleted stands. Furthermore, the present drain on high-quality material could be reduced by eliminating the use of such material for lowquality products; and much of the 190 million cubic feet lost through mortality could be salvaged for low-quality products, along with the material that might be marketed from thinnings and improvement cuttings. 


\section{Future Outlook}

smaller ones are protecting and developing their

$\mathrm{S}$ OUTH Georgia has long been noted for the extent and value of its forest resources. The social and economic structure of the region is intimately connected with the use of the land for growing timber crops and with the manufacture, marketing, and transportation of forest commodities. The forest-using industries have played a major role in the development and progress of the area, and there is every indication that they will play an even greater role in the future if furnished abundant and suitable raw material.

For many years south Georgia has been the heart of the naval stores belt, and the business of producing rosin and turpentine from the longleaf and slash pine forests has been the dominant forest activity for several decades. The forest industries producing lumber, poles, ties, and similar commodities have had in the main to take second place, both in economic importance and in the order of their access to the forest stands. Recent developments, however, seem to indicate that the future may see a change in this situation.

Within the last few years the new pulp mills that have been located in this section of Georgia or nearby have acquired large areas of forest land on which the first objective of management is the production of wood rather than naval stores. Furthermore, the large new outlet for pulpwood from lands other than company-owned is developing a different concept of management. Although the production of gum turpentine and rosin is likely always to be one of the outstanding sources of wealth from longleaf and slash pine forests, increasing profits from integrated utilization, including pulpwood sales, may eventually change it from a primary to a secondary objective of forest management.

In the last 10 years there has been notable progress in forest management in south Georgia. Many of the large forest landowners and some of the forest properties and are using good judgment in the harvesting of their timber crops. It cannot be said, however, that wise forest management is widely prevalent. There is need for continued and intensified fire protection, for better woods practices in gum naval stores, for the removal of cull trees and inferior species, and for greater thrift in utilization. If the thousands of small forest holdings, annually subjected to many forms of debilitating mismanagement, are to be rehabilitated and do their part in maintaining that high degree of productiveness of which the region is capable, forestry educational work must be expanded.

It is essential that the annual increment of the forest be increased if the present wood-using industries are to be assured of an adequate and continuous supply of raw material at a reasonable cost. At present the annual requirement for pine products outstrips the current annual increment. It is true some relief can be furnished by central Georgia, the survey unit adjoining on the north, where pine increment exceeds drain by about a million cords annually. Nevertheless, as the balance between growth and drain now stands, there is a distinct limitation to the extent to which the forest industries can be expanded without facing a gradually declining source of supply.

South Georgia, with so many natural factors favorable to tree growth, should not be content with the comparatively small improvement in growth needed to balance its present forest budget. It should look forward to an intensive development of this, its main natural resource, with the expectation of perhaps doubling its annual yield within the next 20 years. The pressing need for increased industrialization to furnish greater employment for both capital and labor fully justifies a serious and sustained effort to this end. 


\section{ORGANIZATION OF THE UNITED STATES DEPARTMENT OF AGRICULTURE WHEN THIS PUBLICATION WAS LAST PRINTED}

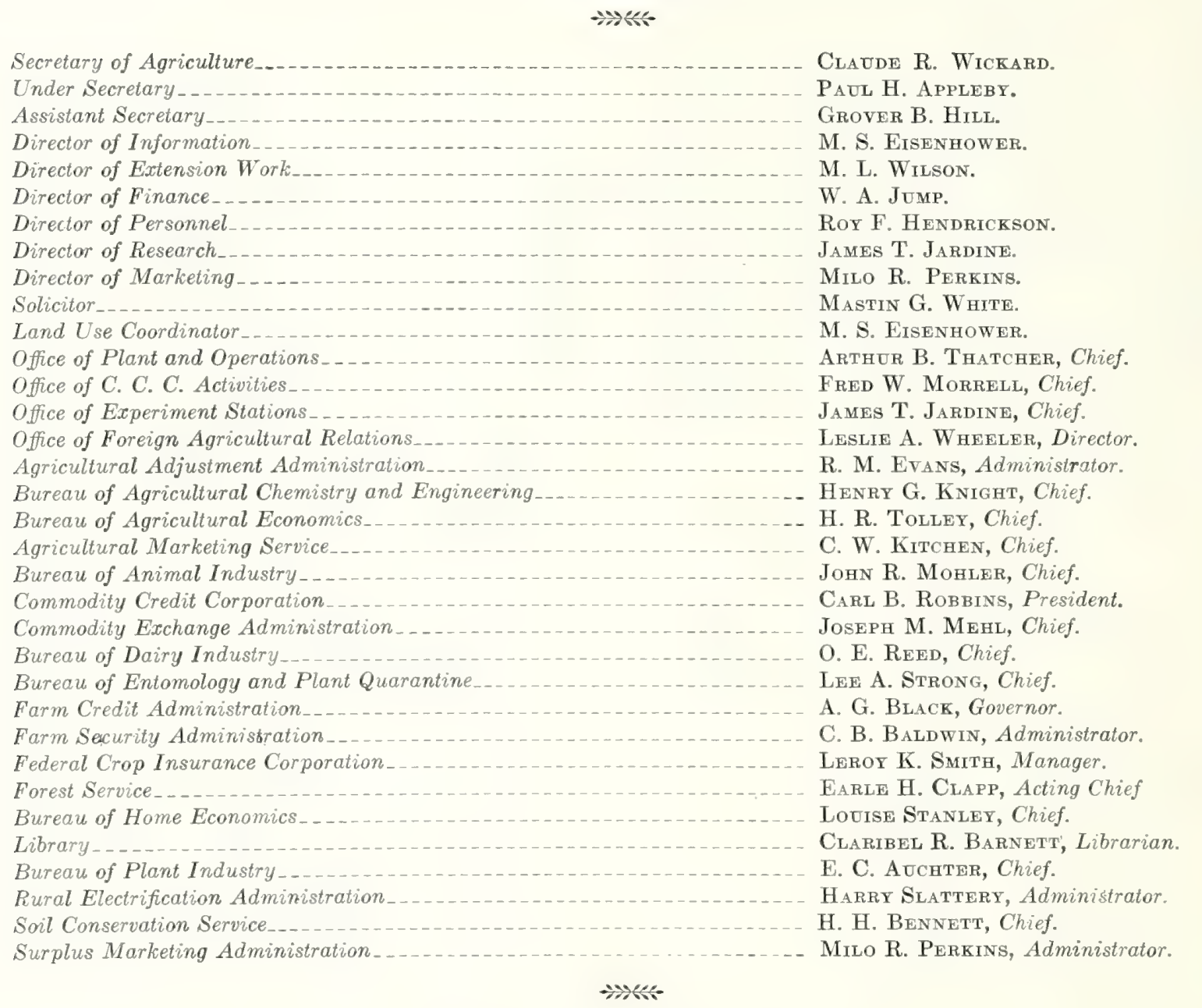

This publication is a contribution from

Forest Service,

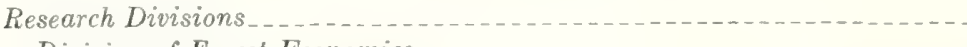

Division of Forest Economics.

Forest Survey

Southern Forest Experiment Station
Earle H. Clapp, Acting Chief.

C. L. Forsuing, Assistant Chief, in Charge.

R. E. Marsh, Acting in Charge.

R. D. Garver, Director.

E. L. Demmon, Director. 





•| 


\section{.} ,

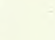

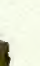

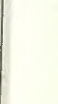

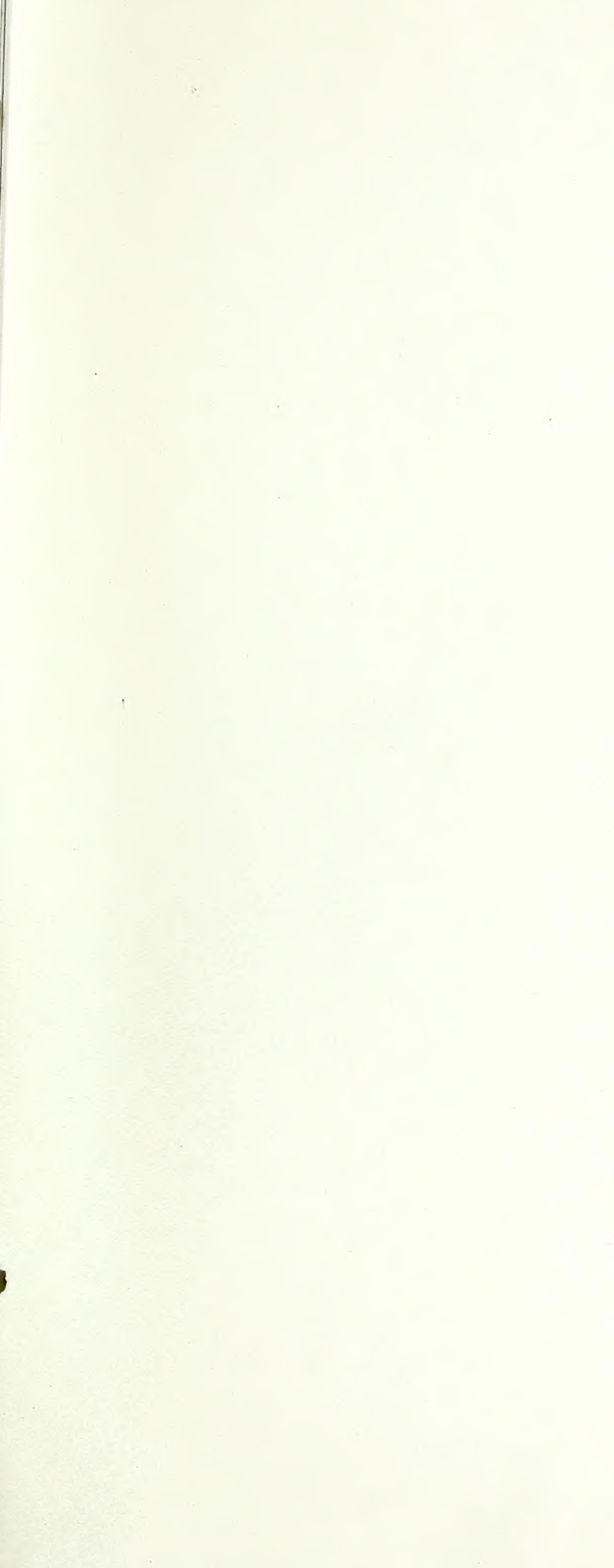

(1)
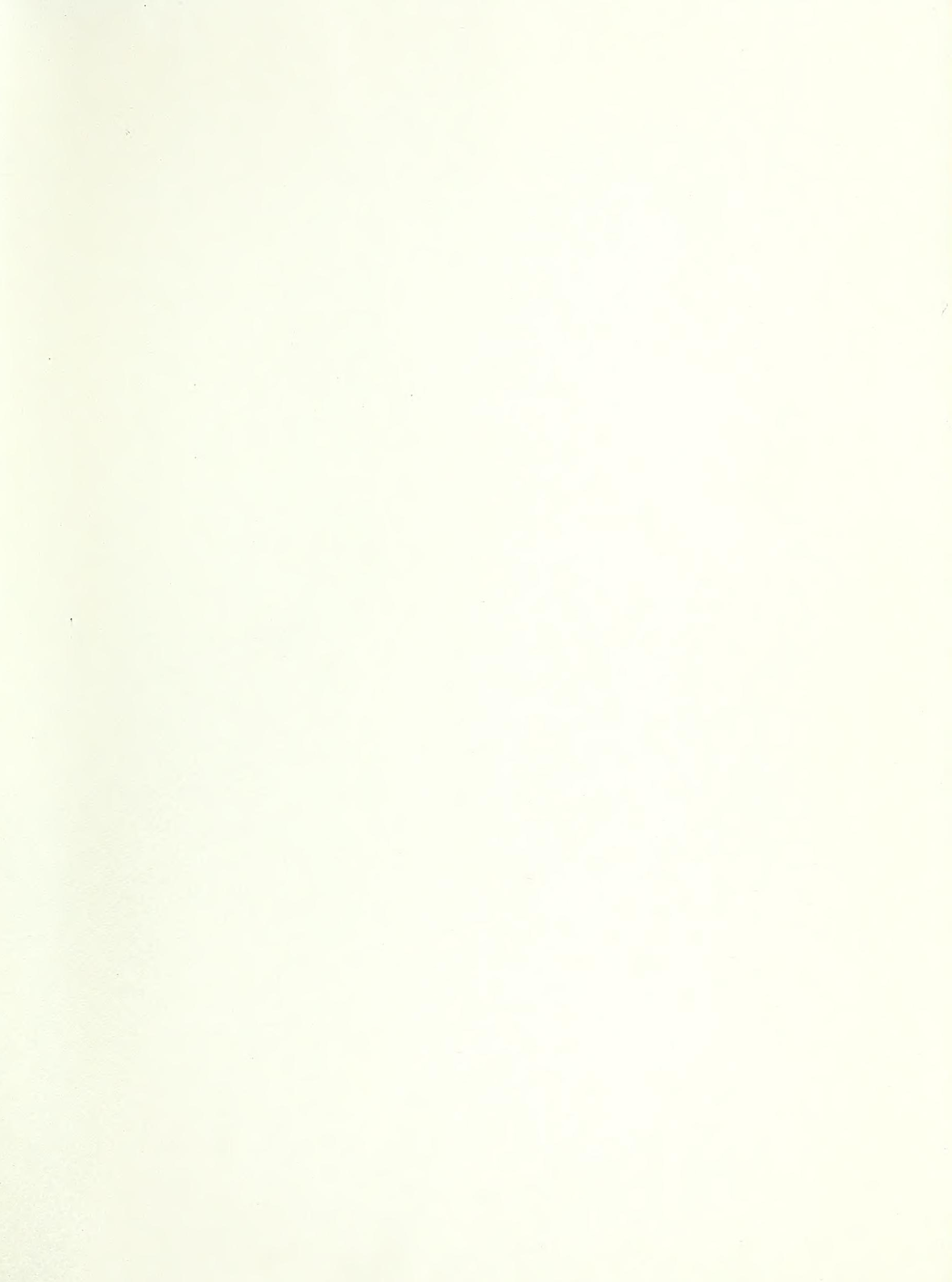

$\checkmark$ 